ADRIANA FERREIRA MALUF BRAGA

Produção de hidrogênio em reatores anaeróbios termofílicos

São Carlos

2014

VERSÃO CORRIGIDA 



\title{
Produção de hidrogênio em reatores anaeróbios termofílicos
}

Tese apresentada à Escola de Engenharia de São Carlos, da Universidade de São Paulo, como parte dos requisitos para obtenção do título de Doutor em Ciências: Engenharia Hidráulica e Saneamento.

Orientador: Prof. Dr. Marcelo Zaiat

\author{
São Carlos \\ 2014 \\ VERSÃO CORRIGIDA
}


AUTORIZO A REPRODUÇÃO TOTAL OU PARCIAL DESTE TRABALHO, POR QUALQUER MEIO CONVENCIONAL OU ELETRÔNICO, PARA FINS DE ESTUDO E PESQUISA, DESDE QUE CITADA A FONTE.

B813p

Braga, Adriana Ferreira Maluf

Produção de hidrogênio em reatores anaeróbios termofílicos / Adriana Ferreira Maluf Braga; orientador Marcelo Zaiat. São Carlos, 2014.

Tese (Doutorado) - Programa de Pós-Graduação e Área de Concentração em Hidráulica e Saneamento -- Escola de Engenharia de São Carlos da Universidade de São Paulo, 2014 .

1. Biohidrogênio. 2. Acidogênese. 3. Solventogênese. 4. UASB. 5. Reator tubular. I. Título. 


\section{FOLHA DE JULGAMENTO}

Candidata: Engenheira ADRIANA FERREIRA MALUF BRAGA.

Título da tese: "Avaliação da produção de hidrogênio em reatores anaeróbios termofílicos".

Data da defesa: 29/04/2014

\section{Comissão Julgadora:}

Prof. Associado Marcelo Zaiat (Orientador)

(Escola de Engenharia de São Carlos/EESC)

Prof. Dr. José Alberto Domingues Rodrigues

(Instituto Mauá de Tecnologia/IMT)

Profa. Dra. Magali Christe Cammarota

(Universidade Federal do Rio de Janeiro/UFRJ)

Prof. Dr. Luiz Olinto Monteggia

(Universidade Federal do Rio Grande do SUI/UFRGS)

Profa. Dra. Paula Loureiro Paulo

(Universidade Federal de Mato Grosso do Sul/UFMS)
Resultado:

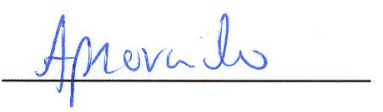

ArRONASO

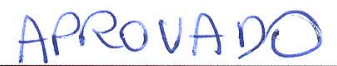

APROVA DO

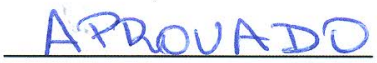

Coordenadora do Programa de Pós-Graduação em Engenharia Hidráulica e Saneamento:

Profa. Associada Maria Bernadete A. Varesche Silva

Presidente da Comissão de Pós-Graduação:

Prof. Titular Denis Vinicius Coury 

Aos meus pais, Doracy e José Luiz, por sempre terem me incentivado a seguir os meus sonhos e pelo apoio incondicional $e$ incansável durante todo o desenvolvimento dessa pesquisa. 



\section{AGRADECIMENTOS}

À Deus, chamado de muitos nomes diferentes, mas que de fato representa uma mesma entidade que deu origem ao universo que nos cerca e nos deu a racionalidade e a curiosidade para tentarmos entende-lo.

A minha família, especialmente, meus pais, José Luiz Maluf Braga e Doracy Ribeiro Ferreira, minha avó, Neusa Salamene Maluf (in memoriam), minha irmã, Alessandra Ferreira Braga, meu cunhado, Wagner de Oliveira Carrilho e meu sobrinho, Ângelo Luiz Braga Carrilho, pelo carinho, pelos momentos renovadores, pelos preciosos ensinamentos e por serem a minha fortaleza e motivação para seguir em frente independente dos obstáculos.

Ao professor Marcelo Zaiat, pela orientação, por estar sempre disposto a compartilhar seu conhecimento e experiência, dando a abertura para discussões, por confiar no meu trabalho e se tornando um grande conselheiro e amigo nesse período.

À aluna de iniciação, Mariana Reis, pelo suporte durante essa pesquisa e pela amizade.

À Escola de engenharia de São Carlos e o Departamento de Hidráulica e Saneamento por permitir a execução desta pesquisa.

À Fapesp pelo apoio financeiro à pesquisa e concessão das bolsas de doutorado (Processo 2010/05495-0) e de estágio e pesquisa no exterior (Processo 2012/21917-7).

À minha família em São Carlos, Taís Arriero Shinma e Aline da Silva Ribeiro, que se tornaram minhas irmãs de coração, me ensinaram muito, me apoiaram em todos os momentos, até nos ensaios em batelada durante a madrugada, choramos 
juntas, rimos juntas e selamos uma amizade que o tempo não apaga. Ao meu outro irmão de coração, Antônio Djalma Nunez Ferraz Jr., pelas produtivas discussões sobre o projeto, pelo exemplo de competência e praticidade, pela ajuda nas madrugadas de medição de biogás, pelos conselhos sobre a vida, por ser muito companheiro (nos momentos de riqueza e de pobreza), sempre com muito bom humor. Aos compadres Marjolly Priscilla Shinzato Bais e Leandro Guimarães Bais Martins por toda a amizade e carinho, pelos conselhos nas decisões difíceis, pelo exemplo de generosidade, por me acolherem nos períodos pré e pós Dinamarca e ao meu afilhado Caio Shinzato Bais por ter trazido mais alegria a esse final de doutorado. Ao amigo Patrick Yuri Shinzato, pelas discussões filosóficas sobre a vida e a pesquisa, pela ajuda na parte computacional, por aguentar as minhas chatices aqui e no Velho Mundo e ser companheiro até no Pólo Norte! Aos amigos Vinicius Carvalho Rocha e Eloá Cristina Figueirinha Pelegrino, que também fazem parte dessa família, com direito à almoços de domingo, sessões de filmes e jogos, nas quais sempre surgiam ideias e pontos de vista interessantes sobre os mais diversos assuntos, me fazendo ver o quão importante esses momentos de descontração são para a saúde mental de qualquer pesquisador, hehehe...

À Melida Del Pilar Anzola Rojas pelo exemplo de coragem e determinação, pela amizade e suporte nos assuntos científicos e pessoais, por me incentivar a fazer o intercâmbio, pela companhia no congresso da China, o qual foi uma aventura desde antes de sairmos do solo brasileiro.

À Bruna de Souza Moraes, pela amizade que nasceu nos corredores do LPB, se solidificou em solo dinamarquês e continua depois do regresso, pelo exemplo de profissionalismo, pelas conversas produtivas, pelos momentos de confidências e pelas aventuras inesquecíveis! Skål!!

Ao Jesus García Sánchez, pela amizade e apoio em todos os momentos, pela contribuição nas diferenças finitas, pelos sábios conselhos e pelas dicas de espanhol, hehehe...

À Vivian Maria Carminato, pelo ombro amigo e sugestões tanto em questões pessoais quanto relativas à pesquisa, por me receber em sua casa e me fazer sentir parte da família no período que me hospedou. 
Aos amigos Mara Rúbia de Lima e Silva, Mariana Fronja Carosia, Carla Eloísa Diniz dos Santos e Theo Syrto Octavio de Souza, colegas de trabalho, companheiros em momentos sérios e de diversão, amizades que foram surgindo e crescendo ao longo do doutorado, que agregaram ainda a Elisa Uliana e Milena Lima e Silva, e agora, no final desse processo, vejo que a amizade desse grupo foi um grande apoio nesse processo e será para a vida toda.

À Priscila Rossetto Camiloti e ao Eduardo Dellosso Penteado, pelo carinho e cumplicidade desde o começo, entramos juntos no grupo e aprendemos muito uns com os outros, sinto-me muito feliz e orgulhosa em ver o crescimento de vocês e sei que esse laço se manterá pelos anos vindouros!

À Lívia Silva Botta, por ser alguém com quem sempre pude contar dentro e fora do laboratório, devido ao seu coração gigante e sua competência no trabalho, e pelos momentos divertidíssimos.

Aos Professores Eugênio Foresti, Maria Bernadete Varesche e Wiclef Dymurgo, pelas contribuições indiretas durante a convivência no LPB e, em especial, à professora Márcia Damianovic, pelas contribuições diretas na banca de qualificação.

Aos amigos que passaram pelo LPB e aos que ainda estão por lá, desculpem não citar o nome de cada um, pois são muitos e eu poderia deixar alguém de fora, mas saibam que sou grata pelas conversas inspiradoras e produtivas durante os cafés, por tornarem o ambiente de trabalho um lugar tão agradável e divertido, espaço de muitas teorias malucas sobre tudo, mas das quais sempre podemos tirar algumas verdades.

Às técnicas do LPB, Eloisa Pozzi, Isabel Kimiko Sakamoto e Carolina Aparecida Sabatini Mirandola pelo suporte durante o desenvolvimento do projeto e, em especial, à Maria Angela Tallarico Adorno, responsável pela cromatografia, por me socorrer em momentos críticos, fossem eles à noite ou aos fins de semana. Aos técnicos Fernando Garutti Moura pelo suporte na parte de informática e seu Edson na parte elétrica. 
Aos funcionários da segurança e limpeza do bloco da Engenharia Ambiental, em especial à dona Rosa, ao por serem sempre muito prestativos.

Aos funcionários do Campus 1, Maria Auxiliadora de C. Altieri Pin (mais conhecida como Sá), Rosemeire Aparecida de Jesus, Priscila Carla Toselli de Almeida, Fernanda Maria Struzziatto Machado, Flávia Gialorenço Canova e André Canale Garcia pelo suporte e solicitude nas questões administrativas e de informática.

I would like to thank the University of Southern Denmark (SDU) for welcoming me to internship, professor Knud Villy Christensen for supervising me and for valuable discussions throughout development of the project in Denmark and professor Birgir Norddahl for informal conversations and suggestions that somehow contributed to the project. Tak skal du have.

I'm also thankful to Chandrakant Malwade, Behnaz Razi Parjikolaei, Maria Salud Camilleri Rumbau, Rime Bahij El-Houri, Theoharis Ouzounis, Theopoula Gkenou, Nataša Čereković, Ioanna Mavrokefalidou, Ana Filipa Gomes, Fábio Gomes, Agata Zarebska and Nicolas Givaudan for the friendship and support during my stay in Denmark, you've made this period be very special for me and l've learned a lot with each of you.

Por mais que tente não conseguirei agradecer aqui a todos que os que contribuíram de forma direta e indireta ao projeto e aos amigos me deram suporte durante esses quatro anos, mesmo de longe, mas isso não diminui a importância e nem a gratidão que sinto por vocês! 
"Nada é tão perigoso ao desenvolvimento da mente humana quanto supor que nossa visão científica alcançou seu máximo, que não há mistérios na natureza, que nossos triunfos estão completos e que não há novos mundos para se conquistar".

Humphry Davy 



\section{Resumo}

BRAGA, A. F. M. Produção de hidrogênio em reatores anaeróbios termofílicos. Tese (Doutorado), Departamento de Hidráulica e Saneamento, Escola de Engenharia de São Carlos, Universidade de São Paulo. 118 p. São Carlos, 2014.

A digestão anaeróbia termofílica é uma opção vantajosa para efluentes descartados a altas temperaturas, além de estimular rotas mais eficientes de produção de $\mathrm{H}_{2}$. No entanto, os resultados da literatura divergem bastante, os rendimentos de $\mathrm{H}_{2}$ são inferiores ao valor teórico possível e poucos estudos avaliaram diferentes configurações para indicar a mais eficiente. Assim, este estudo avaliou a produção de $\mathrm{H}_{2}$ a partir da sacarose em três tipos de reator: reator anaeróbio de fluxo ascendente e manta de lodo (UASB), reator tubular de fluxo ascendente com leito empacotado (TCS) e sem material suporte (TSS), operados a $55^{\circ} \mathrm{C}$. Os tempos de detenção hidráulica (TDH) aplicados ao reator UASB foram 12, 6 e $2 \mathrm{~h}$ e aos reatores TCS e TSS foram 2 e $0,5 \mathrm{~h}$. Pré-tratamento térmico $\left(100^{\circ} \mathrm{C}\right.$ por $\left.15 \mathrm{~min}\right)$ foi aplicado ao inóculo metanogênico do UASB e TCS e TSS foram auto inoculados. O efeito de nutrientes e a concentração nutricional ótima para a produção de $\mathrm{H}_{2}$ foram investigados através de ensaios em batelada. Com TDH de 2 h, o material suporte afetou a transferência de massa, resultando em menor teor de $\mathrm{H}_{2}$ no biogás quando presente, porém, maior conversão de sacarose e produção de $\mathrm{H}_{2}$. O pré-tratamento térmico não inibiu a metanogênese, sendo as condições operacionais mais importantes para a seleção dos microrganismos. TCS e TSS com TDH de 0,5 h apresentaram produção de $\mathrm{H}_{2}$ similar e o material suporte afetou apenas as rotas metabólicas. Entre todas as operações, TCS e UASB com TDH de $2 \mathrm{~h}$ alcançaram os maiores valores de rendimento de $\mathrm{H}_{2}\left(\mathrm{YH}_{2}\right)$, respectivamente, 1,99 $\pm 0,36$ e 2,56 \pm 0,84 $\mathrm{molH}_{2}$ mol-sac ${ }^{-1}$, através da via metabólica do etanol. TCS2 também demonstrou estabilidade e, apesar de o U2 ter gerado maiores porcentagens de $\mathrm{H}_{2}$ no biogás, pode ser apontado como o mais eficiente para a produção de $\mathrm{H}_{2}$. A relação C:N:P, $\mathrm{Fe}^{+2}$ e $\mathrm{Ni}^{+2}$ tiveram efeito significativo sobre a produção de $\mathrm{H}_{2}$, e $\mathrm{YH}_{2}$ ótimo foi estimado para concentrações de $4,53 \mathrm{mgFe}{ }^{+2} \cdot \mathrm{L}^{-1}$ e $0,045 \mathrm{mgNi}^{+2} \cdot \mathrm{L}^{-1}$.

Palavras-chave: Biohidrogênio. Acidogênese. Solventogênese. UASB. Reator tubular 


\section{Abstract}

BRAGA, A. F. M. Hydrogen production in anaerobic thermophilic reactors. Tese (Doutorado), Departamento de Hidráulica e Saneamento, Escola de Engenharia de São Carlos, Universidade de São Paulo. 118 p. São Carlos, 2014.

The thermophilic anaerobic digestion is a suitable option for wastewater discharged at high temperatures; in addition, it is suitable for more efficient pathways for $\mathrm{H}_{2}$ production. However, the results found in literature have divergences; the $\mathrm{H}_{2}$ yields are lower than the theoretical possible value and only few studies evaluated different types of reactors and defined the more advantageous one. Therefore, this study evaluated $\mathrm{H}_{2}$ production from sucrose in three types of reactor: upflow anaerobic sludge blanket (UASB), upflow tubular reactor with packed-bed (TCS) and without support materials (TSS), operated at $55^{\circ} \mathrm{C}$. The hydraulic retention time (HRT) applied to UASB reactor was 12, 6 and $2 \mathrm{~h}$ and to TCS and TSS was 2 and $0.5 \mathrm{~h}$. Thermal pretreatment (at $100^{\circ} \mathrm{C}$, for $15 \mathrm{~min}$ ) was applied to the methanogenic inoculum of UASB and TCS and TSS was inoculated through natural fermentation process. The effect of nutrients and the optimal concentration of $t$ nutrients for $\mathrm{H}_{2}$ production were evaluated through batch assays. At HRT of $2 \mathrm{~h}$, the support material affected the mass transferring, leading to lower content of $\mathrm{H}_{2}$ in the biogas when it is used; however, in this condition it was found higher sucrose conversion and $\mathrm{H}_{2}$ production. The operational conditions showed to be more efficient for methanogenesis than pretreatment. TCS and TSS at HRT of $0.5 \mathrm{~h}$ presented similar $\mathrm{H}_{2}$ production and the support material affected only the metabolic pathways. Among all the conditions assessed, TCS and UASB at HRT of $2 \mathrm{~h}$ reached the highest values of $\mathrm{H}_{2}$ yield highest $\mathrm{YH}_{2}$, respectively, $1.99 \pm 0.36$ and $2.56 \pm 0.84 \mathrm{molH}_{2} . \mathrm{mol}_{-\mathrm{sac}^{-1}}$, through ethanol pathway. TCS2 demonstrated stability production also and, despite the $\mathrm{U} 2$ have achieved higher percentage of $\mathrm{H}_{2}$ in biogas, it can be pointed out as more efficient for $\mathrm{H}_{2}$ production. The ratio $\mathrm{C}: \mathrm{N}: \mathrm{P}, \mathrm{Fe}^{+2}$ and $\mathrm{Ni}^{+2}$ showed significant effect on $\mathrm{H}_{2}$ production, and the optimal $\mathrm{YH}_{2}$ was estimated for $4.53 \mathrm{mgFe} \mathrm{F}^{+2} \cdot \mathrm{L}^{-1} \mathrm{e}$ $0.045 \mathrm{mgNi}^{+2} \cdot \mathrm{L}^{-1}$.

Keywords: Biohydrogen, Acidogenesis, Solventogenesis, UASB, Tubular reactor. 
xviii 


\section{LISTA DE FIGURAS}

Figura 1 - Dimensões e esquema do reator tubular. ..........................................54

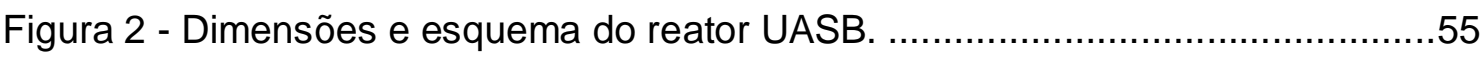

Figura 3 - Material suporte cortado e gráfico de sua granulometria. .......................57

Figura 4 - Reatores operando em fluxo contínuo. A - UASB; B - leito fixo...............59

Figura 5 - Curvas $E_{\theta}$ função de $\theta$ obtidas para cada operação. ............................71

Figura 6 - Grânulos utilizados para a inoculação do reator $(A)$ e grânulos ao final da

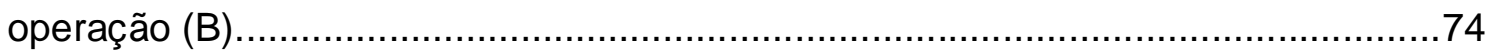

Figura 7 - Porcentagem de $\mathrm{H}_{2}$ e $\mathrm{CH}_{4}$ no biogás (A), $\mathrm{pH}$ e e a concentração de sólidos suspensos voláteis (SSV) no efluente (B) durante as operações em reator UASB: USU, partida do reator; U12, UASB com TDH de 12h; U6, UASB com TDH de 2. .75

Figura 8 - Visão geral do desempenho do reator UASB na produção de $\mathrm{H}_{2}$ em todas as etapas: USU, partida do reator; U12, UASB com TDH de 12h; U6, UASB com TDH de 2.. VMH: vazão molar de $\mathrm{H}_{2}$; $\mathrm{PVH}$ : produção volumétrica de $\mathrm{H}_{2}$; CS: conversão de sacarose; $\mathrm{YH}_{2}$ : rendimento de $\mathrm{H}_{2}$. .78

Figura 9 - Concentração dos produtos metabólicos solúveis (PMS) produzidos através da acidogênese e solventogênese em reator UASB: USU, partida do reator; U12, UASB com TDH de 12h; U6, UASB com TDH de 2.

Figura 10 - Conversão de sacarose (CS) e a concentração de sólidos suspensos voláteis (SSV) no efluente no reator tubular com leito empacotado e operado com TDH de $2 \mathrm{~h}(\mathrm{~A})$ e $0,5 \mathrm{~h}(\mathrm{~B})$ 81

Figura 11 - Visão geral do desempenho do reator TCS na produção de $\mathrm{H}_{2}$. Porcentagem de $\mathrm{H}_{2}$ no biogás e VMH - vazão molar de $\mathrm{H}_{2}(\mathrm{~A}-\mathrm{TDH}$ de $2 \mathrm{~h}$ e $\mathrm{B}-\mathrm{TDH}$ de $0,5 \mathrm{~h}) ; \mathrm{YH}_{2}$ - rendimento de $\mathrm{H}_{2}$ e pH (C - TDH de $2 \mathrm{~h}$ e D - TDH de 0,5h)..... 82

Figura 12 - Concentração dos produtos metabólicos solúveis (PMS) produzidos no reator tubular com leito empacotado e TDH de $2 \mathrm{~h}$ (TCS2) e 0,5h (TCS). 
Figura 13 - Conversão de sacarose (CS) e concentração de sólidos suspensos voláteis (SSV) no efluente do reator tubular sem suporte e operado com TDH de $2 \mathrm{~h}$ (A) e $0,5 \mathrm{~h}$ (B). 86

Figura 14 - Visão geral do desempenho do reator TSS na produção de $\mathrm{H}_{2}$. Porcentagem de $\mathrm{H}_{2}$ no biogás e VMH - vazão molar de $\mathrm{H}_{2}(\mathrm{~A}$ - TDH de $2 \mathrm{~h}$ e $\mathrm{B}$ - TDH de 0,5h); $\mathrm{YH}_{2}$ - rendimento de $\mathrm{H}_{2}$ e pH (C - TDH de $2 \mathrm{~h}$ e D - TDH de 0,5h).... 87 Figura 15 - Concentração dos produtos metabólicos solúveis (PMS) produzidos no reator tubular sem material suporte e TDH de $2 \mathrm{~h}$ (TSS2) e 0,5h (TSS). 89

Figura 16 - Principais variáveis obtidas com os reatores operados com TDH de 2h: A - porcentagem de $\mathrm{H}_{2}$ no biogás; $\mathrm{B}$ - $\mathrm{PVH}$, produção volumétrica de $\mathrm{H}_{2}$; $\mathrm{C}-\mathrm{YH}_{2}$, rendimento de $\mathrm{H}_{2}$; D - PMS, produto metabólico solúvel: $\mathrm{EtOH}$ (entanol), $\mathrm{MeOH}$ (metanol), Hbu (ácido butírico), Hpr (ácido propiônico), Hac (ácido acético), Hfo (ácido fórmico), Hla (ácido lático). 90

Figura 17 - Principais variáveis obtidas com os reatores operados com TDH de 0,5h: A - porcentagem de $\mathrm{H}_{2}$ no biogás; $\mathrm{B}-\mathrm{PVH}$, produção volumétrica de $\mathrm{H}_{2} ; \mathrm{C}-\mathrm{YH}_{2}$, rendimento de $\mathrm{H}_{2}$; D - PMS, produto metabólico solúvel: $\mathrm{EtOH}$ (entanol), $\mathrm{MeOH}$ (metanol), Hbu (ácido butírico), Hpr (ácido propiônico), Hac (ácido acético), Hfo (ácido fórmico), $\mathrm{Hla}$ (ácido lático). 92

Figura 18 - Agrupamento das comunidades microbianas nas operações do reator UASB: nos dias 110 (U12A), 211 (U12B), 282 (U6) e 366 (U2). 100

Figura 19 - Agrupamento das comunidades microbianas nas operações dos reatores tubular com leito empacotado (TCS), tanto no leito empacotado (LE: TCS2LE, para TDH de $2 \mathrm{~h}$, e TCS0,5LE para TDH de 0,5 h) quanto no compartimento de acúmulo de biomassa (CA: TCS2CA, para TDH de 2, e TCS0,5CA para TDH de 0,5);tubular sem material suporte (TSS) e UASB com TDH de 2 h (U2).

Figura 20 - Diagramas de Pareto mostrando os efeitos de cada nutriente sobre a velocidade molar de produção de $\mathrm{H}_{2}(\mathrm{~A})$ e rendimento de $\mathrm{H}_{2}(B)$. 103 Figura 21 - Superfícies de resposta das variáveis $\mathrm{VPH}(\mathrm{A})$ e $\mathrm{YH}_{2}(\mathrm{~B})$ em função de seus respectivos fatores influentes. 105 Figura 22 - Superfície de resposta para a variável $\mathrm{YH}_{2}$ em relação às concentrações de $\mathrm{Fe}^{2+}$ e $\mathrm{Ni}^{2+}$. 107 


\section{LISTA DE TABELAS}

Tabela 1 - Condições de operação dos reatores na fase 1. 59 Tabela 2 - Concentrações e nutrientes testados no planejamento Plackett-Burman.

Tabela 3 - Concentrações utilizadas no planejamento pelo método da diagonal de maior inclinação. 68

Tabela 4 - Valores para a região ótima testados no planejamento Composto Central. 69

Tabela 5 - Valores para a região ótima testados no segundo experimento

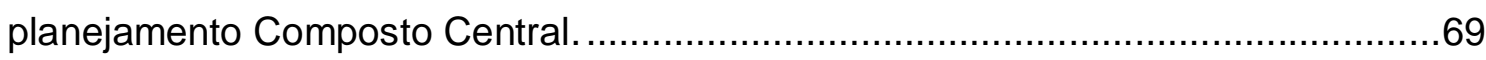

Tabela 6 - Dados experimentais dos ensaios hidrodinâmicos.................................72 Tabela 7 - Valores médios obtidos para as variáveis de produção de $\mathrm{H}_{2}$ ao longo da operação do reator UASB. .76

Tabela 8 - Valores médios obtidos para as variáveis da produção de $\mathrm{H}_{2}$ durante o período de estabilidade das operações TCS2 e TCS0,5. 83

Tabela 9 - Valores médios obtidos para as variáveis da produção de $\mathrm{H}_{2}$ durante o período de estabilidade para TSS2 e durante toda a operação de TSS0,5. 88

Tabela 10 - Valores médios dos coeficientes de rendimento dos PMS (YPMS). .....93 Tabela 11 - Balanço estequiométrico de $\mathrm{H}_{2}$, baseado em 1 mol de sacarose convertida. 96

Tabela 12 - Avaliação da estabilidade e principais PMS produzidos nas configurações de reatores testadas no presente estudo 99

Tabela 13 - Avaliação da estabilidade e principais PMS produzidos nas configurações de reatores testadas no presente estudo 99

Tabela 14 - Matriz Plackett-Burman e os valores de VPH e $\mathrm{YH}_{2}$ para cada ensaio. 
Tabela 15 - Resultados obtidos com o planejamento pelo método da diagonal de

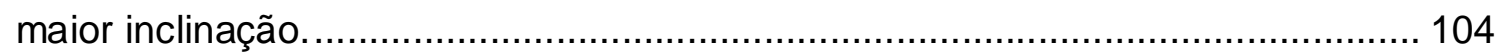
Tabela 16 - Matriz do planejamento Composto Central e resultados obtidos........ 105 Tabela 17 - Matriz do planejamento Composto Central variando apenas $\mathrm{Fe}^{+2}$ e $\mathrm{Ni}^{+2}$

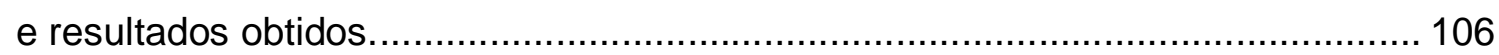




\section{Lista de AbREVIATURAS e Siglas}

AGV

ANOVA

CLAE

COV

CS

CSTR

DGGE

DNA

DP

DQO

DTR

EP

EPS

$\mathrm{EtOH}$

$\mathrm{Hac}$

$\mathrm{Hbu}$
Ácidos Graxos Voláteis

Analise de Variância (Analysis Of Variance)

Cromatografia Líquida de Alta Eficiência

Carga Orgânica Volumátrica

Conversão de Sacarose

Reatores de Mistura Completa (Continuous Stirred Tank Reactor)

Eletroforese em Gel de Gradiente Desnaturante

Ácido Desoxirribonucleico (Deoxyribonucleic Acid)

Desvio Padrão

Demanda Química de Oxigênio

Distribuição de Tempo de Residência

Erro Padrão

Exopolissacarídeo

Etanol

Ácido acético

Ácido butírico 
Hfo

Hla

$\mathrm{Hpr}$

IPCC

$\mathrm{MeOH}$

$\mathrm{NAD}^{+}$

$\mathrm{NADH}$

NFOR

PCR

PFL

PFOR

PHA

PHB

PMS

PVH

rRNA

SSV

SVT

TCS

TDH
Ácido fórmico

Ácido lático

Ácido propiônico

Painel Intergovernamental de Mudanças Climáticas

(Intergovernmental Panel on Climate Change)

Metanol

Nicotinamida Adenina Dinucleotídeo oxidada

Nicotinamida Adenina Dinucleotídeo reduzida

NADH:Ferrodoxina Oxidoredutase (NADH: Ferredoxin

Oxidoreductase)

Reação em Cadeia De Polimerase (Polymerase Chain Reaction)

Lise Piruvato:Formiato (Pyruvate:Formate Lyase)

Piruvato:Ferrodoxina Oxidoredutase (Pyruvate: Ferredoxin

Oxidoreductase)

Polihidroxialcanoato

Poli- $\beta$-Hidroxibutirato

Produto Metabólico Solúvel

Produção Volumétrica de Hidrogênio

Ácido Ribonucleico Ribossômico (Ribosomal Ribonucleic Acid)

Sólidos Suspensos Voláteis

Sólidos Voláteis Totais

Tubular Com Leito Empacotado (Tubular Com Suporte)

Tempo de Detenção Hidráulica 
$x x v$

TRC

TSS

UASB

$\mathrm{VMH}$

VMPH

$\mathrm{YH}_{2}$

YPMS
Tempo de Retenção Celular

Tubular Sem Material Suporte (Tubular Sem Suporte)

Reator Anaeróbio de Manta de Lodo e escoamento ascensional (Upflow Anaerobic Sludge Blanket)

Vazão Molar de Hidrogênio

Velocidade Molar de Produção de Hidrogênio

Coeficiente de Rendimento de Hidrogênio

Coeficiente de Rendimento do Produto Metabólico Solúvel 
xxvi 


\section{LISTA dE SímBOLOS}

\begin{tabular}{|c|c|}
\hline$\overline{\theta_{\mathrm{h}}}$ & TDH médio \\
\hline$C_{S f}$ & Concentração de sacarose no efluente \\
\hline$C_{S o}$ & Concentração de sacarose no meio afluente \\
\hline$M M_{S}$ & Massa molar da sacarose \\
\hline$v_{S}$ & Velocidade molar de sacarose convertida \\
\hline${ }^{\circ} \mathrm{C}$ & Graus Celsius \\
\hline$\mu \mathrm{L}$ & microlitro \\
\hline$\mu \mathrm{m}$ & micrômetro \\
\hline atm & Atmosfera \\
\hline$C: N: P$ & Relação carbono-nitrogênio-fósforo \\
\hline C:N & Relação carbono-nitrogênio \\
\hline$C: P$ & Relação carbono- fósforo \\
\hline $\mathrm{C}_{12} \mathrm{H}_{22} \mathrm{O}_{11}$ & Sacarose \\
\hline $\mathrm{CaCl}_{2}$ & Cloreto de cálcio \\
\hline $\mathrm{CH}_{3}\left(\mathrm{CH}_{2}\right)_{2} \mathrm{COOH}$ & Ácido butírico \\
\hline $\mathrm{CH}_{3} \mathrm{CH}_{2} \mathrm{COOH}$ & Ácido propiônico \\
\hline $\mathrm{CH}_{3} \mathrm{CH}_{2} \mathrm{OH}$ & Etanol \\
\hline
\end{tabular}


xxviii

$\mathrm{CH}_{3} \mathrm{CHOHCOOH}$ Ácido lático

$\mathrm{CH}_{3} \mathrm{COCOOH} \quad$ Piruvato

$\mathrm{CH}_{3} \mathrm{COOH} \quad$ Ácido acético

$\mathrm{CH}_{3} \mathrm{COSCoA} \quad$ Acetil Coenzima A

$\mathrm{CH}_{3} \mathrm{OH} \quad$ Metanol

$\mathrm{CH}_{4} \quad$ Metano

$\mathrm{CH}_{4} \mathrm{~N}_{2} \mathrm{O} \quad$ Uréia

$\mathrm{C}_{\mathrm{i}} \quad$ Concentração no instante $\mathrm{i}$

cm Centímetro

$\mathrm{C}_{\operatorname{máx}} \quad$ Concentração máxima

$\mathrm{Co}^{+2} \quad$ Cobalto na forma iônica

$\mathrm{CO}_{2} \quad$ Dióxido de carbono

$\mathrm{CoASH} \quad$ Coenzima A

$\mathrm{CoCl}_{2} \quad$ Cloreto de cobalto

d Dia

D Diâmetro

D/uL dispersão longitudinal

dt Derivada em função do tempo

$\mathrm{E}_{\theta} \quad \mathrm{E}$ dividido pelo TDH médio

Fd Ferrodoxina

$\mathrm{FdH}_{2} \quad$ Ferrodoxina reduzida 
$\mathrm{Fe}$

$\mathrm{Fe}^{+2}$

$\mathrm{FeCl}_{3}$

$\mathrm{FeSO}_{4}$

$F_{m}$

g

h

$\mathrm{H}^{+}$

$\mathrm{H}_{2}$

$\mathrm{H}_{2} \mathrm{O}$

$\mathrm{H}_{2} \mathrm{SO}_{4}$

$\mathrm{h}_{\mathrm{c}}$

$\mathrm{HCl}$

$\mathrm{HCOOH}$

$\mathrm{K}_{2} \mathrm{HPO}_{4}$

$\mathrm{KH}_{2} \mathrm{PO}_{4}$

L

$\mathrm{Mg}$

mg

$\mathrm{MgCl}_{2}$

$\min$
Ferro

Ferro na forma de íon ferroso

Cloreto férrico

Sulfato ferroso

Fator de calibração do medidor

Grama

hora

Íon hidrogênio

Hidrogênio molecular

Água

Ácido sulfúrico

Altura de cada compartimento

Ácido clorídrico

Ácido fórmico

Fosfato de potássio dibásico

Fosfato de potássio monobásico

Litro

Magnésio

Miligramas

Cloreto de magnésio

minuto 


\begin{tabular}{|c|c|}
\hline $\mathrm{mm}$ & Milímetro \\
\hline $\mathrm{N}$ & Número de tanques-em-série \\
\hline $\mathrm{Na}$ & Sódio \\
\hline $\mathrm{Na}^{+2}$ & Sódio na forma iônica \\
\hline $\mathrm{Na}_{2} \mathrm{HPO}_{4}$ & Fosfato de sódio dibásico \\
\hline $\mathrm{NaCl}$ & Cloreto de sódio \\
\hline $\mathrm{n}_{\mathrm{CH} 4}$ & Número de mols de $\mathrm{CH}_{4}$ \\
\hline $\mathrm{n}_{\mathrm{CO} 2}$ & Número de mols de $\mathrm{CO}_{2}$ \\
\hline $\mathrm{n}_{\mathrm{H} 2}$ & Número de mols de $\mathrm{H}_{2}$ \\
\hline $\mathrm{Ni}$ & Níquel \\
\hline $\mathrm{Ni}^{+2}$ & Níquel na forma iônica \\
\hline $\mathrm{NiSO}_{4}$ & Sulfato de níquel \\
\hline$p$ & Nível descritivo \\
\hline PA & Padrão \\
\hline$i V_{\mathrm{L}}$ & Índice de vazios do leito \\
\hline$P_{p}$ & Porcentagem que passou \\
\hline$P_{r}$ & Porcentagem retida \\
\hline$Q_{g}$ & Vazão de biogás \\
\hline sac & Sacarose \\
\hline $\mathrm{Se}^{2}$ & Selênio na forma iônica \\
\hline $\mathrm{SeO}_{2}$ & Óxido de selênio \\
\hline
\end{tabular}


Tempo

TCS0,5

Tubular com leito empacotado e TDH de 0,5h

TCS2

Tubular com leito preenchido e TDH de $2 \mathrm{~h}$

TSS0,5

Tubular sem suporte e TDH de 0,5h

TSS2

Tubular sem material suporte e TDH de $2 \mathrm{~h}$

U12

UASB com TDH de $12 \mathrm{~h}$

U2

UASB com TDH de $2 \mathrm{~h}$

U6

UASB com TDH de $6 \mathrm{~h}$

USU

Partida (start up) UASB

$\mathrm{v}_{\mathrm{asc}}$

Velocidade ascensional

$\mathrm{V}_{\mathrm{c}}$

Volume dos compartimentos

$\mathrm{V}_{\mathrm{Ip}}$

Volume do leito preenchido

$\mathrm{V}_{\mathrm{IV}}$

Volume de leito vazio

$\mathrm{V}_{\mathrm{m}}$

Volume de gás marcado pelo medidor

$\mathrm{Zn}$

Zinco

$\mathrm{ZnCl}_{2}$

Cloreto de zinco

$\Delta$

Incrementos na concentração

$\theta$

Tempo dividido pelo TDH médio

$\sigma^{2}$

Variância

$\sigma \theta^{2}$

Variância admensional 
xxxii 


\section{SUMÁRIO}

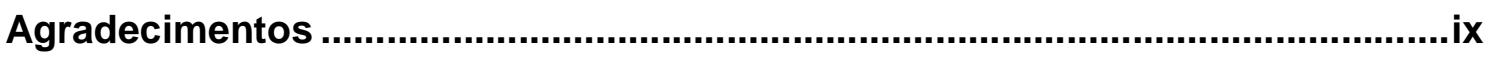

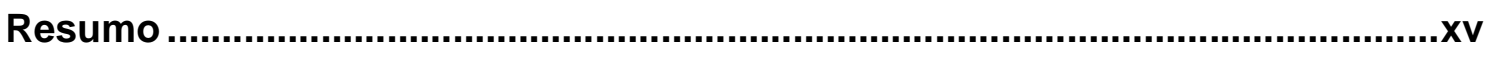

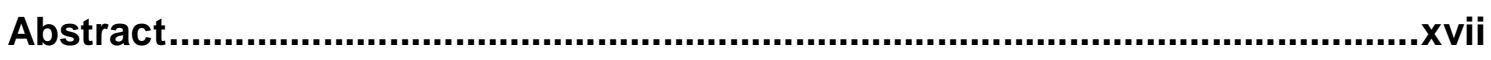

Lista de Figuras .............................................................................................. xix

Lista de Tabelas ............................................................................................xxi

Lista de Abreviaturas e Siglas ................................................................ xxiii

Lista de Símbolos..................................................................................xxvii

Sumário .......................................................................................................xxxiii

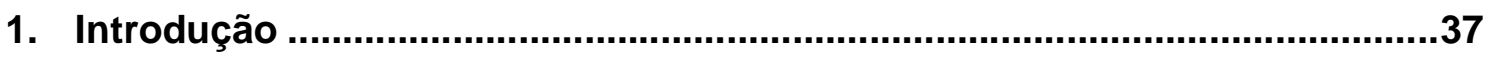

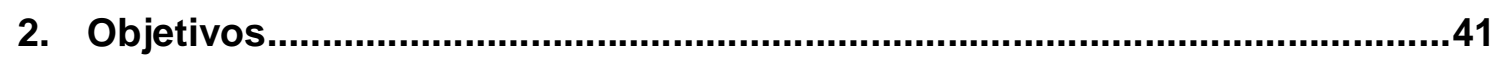

2.1. Objetivo Geral ...........................................................................41

2.2. Objetivos Específicos .................................................................... 41

3. Revisão Bibliográfica............................................................................. 43

3.1. Rotas metabólicas de produção de hidrogênio por via anaeróbia fermentativa................................................................................................43

3.2. Influência da temperatura no processo fermentativo ........................45 
3.3. Influência da configuração do reator e tempo de detenção hidráulica

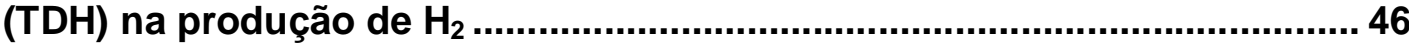

3.4. Efeito das condições nutricionais para a produção de $\mathrm{H}_{2}$................. 49

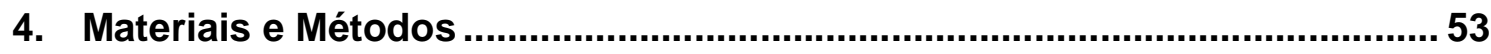

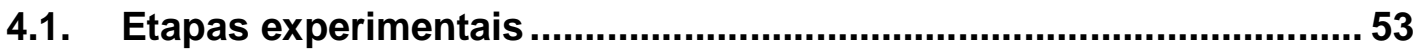

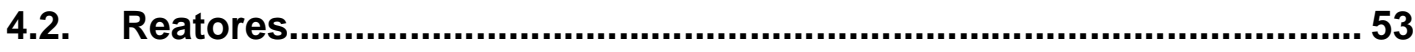

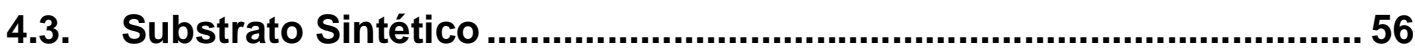

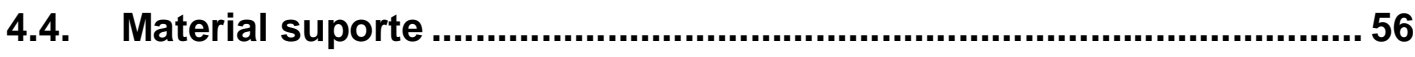

4.4.1. Granulometria do material suporte .................................................56

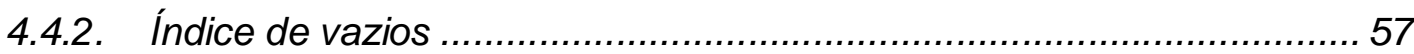

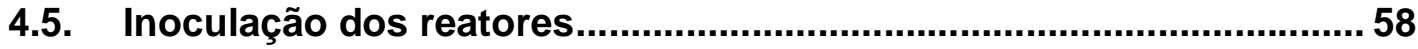

4.6. Protocolo experimental da etapa 1 - Operação de reatores contínuos 58

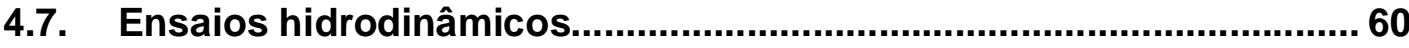

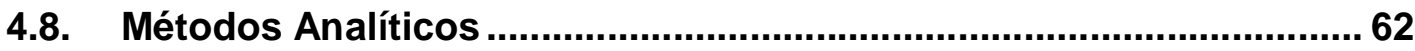

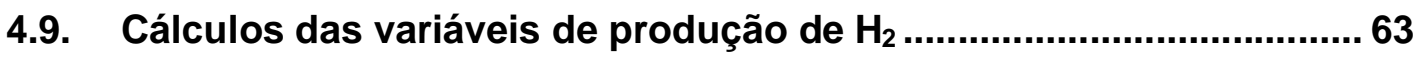

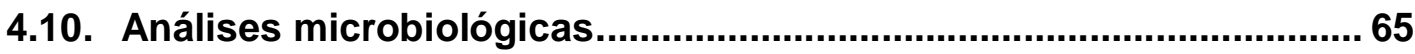

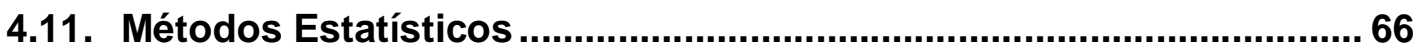

4.12. Protocolo experimental da etapa 2 - Verificação da condição

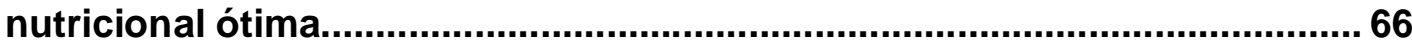

4.12.1. Planejamento fatorial do experimento em batelada ............................67

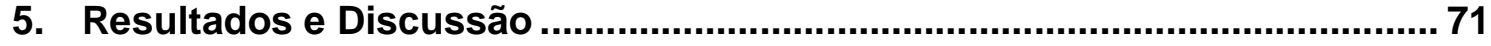

5.1. Etapa 1 - Operação de reatores ....................................................... 71

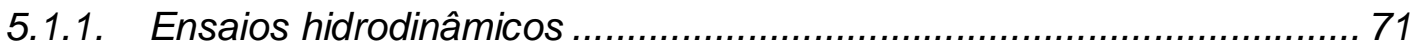

5.1.2. Influência do TDH na operação do reator UASB................................. 74

5.1.3. Influência do TDH na operação do reator tubular com leito empacotado 80 
5.1.4. Influência do TDH na operação do reator tubular sem leito empacotado 85

5.1.5. Influência do tipo de reator na produção de hidrogênio.

5.1.6. Considerações sobre rotas metabólicas 92

5.1.7. Definição da melhor configuração ................................................ 98

5.1.8. Análise microbiológica nos reatores .........................................100

5.2. Etapa 2 - Verificação da condição nutricional ótima .........................101

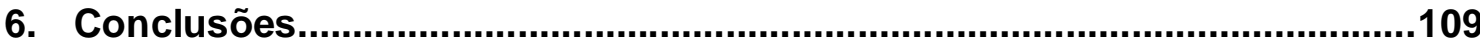

7. Sugestões para trabalhos futuros ...........................................................111

8. Referências Bibliográficas .....................................................................113 
$x x x v i$ 


\section{INTRODUÇÃo}

A relação entre as atividades antrópicas, entre elas a queima de combustíveis fósseis, e as mudanças climáticas vem sendo tema de grandes discussões no campo científico, tendo sido confirmada no relatório de 2013 do Painel Intergovernamental de Mudanças Climáticas (IPCC). Assim, a necessidade de transição da matriz energética mundial para alternativas limpas e sustentáveis deve se tornar uma das questões prioritárias dos governos ao redor do mundo. Nesse contexto, a geração de energia a partir do gás hidrogênio aparece como excelente opção, pois sua combustão gera apenas água. No entanto, a forma e fontes de produção do gás hidrogênio são determinantes para o cumprimento do objetivo de sustentabilidade no uso desse carreador energético.

O gás hidrogênio pode ser produzido a partir de combustíveis fósseis (reforma do gás natural, oxidação parcial de hidrocarbonetos, gaseificação do carvão), de fontes renováveis (hidrólise a partir da energia solar, energia eólica, energia hidroelétrica) e por processos biológicos (fotossinteticamente, por foto-fermentação ou fermentação anaeróbia).

Dentre os processos utilizados, os biológicos têm se destacado nos últimos anos, principalmente pelo custo mais baixo e por permitirem a geração de hidrogênio a partir de matérias-primas renováveis, como resíduos orgânicos por bactérias fermentativas e de $\mathrm{CO}_{2}$ por microrganismos autótrofos fotossintetizantes. As duas vias, fotossintética e fermentativa, têm sido amplamente estudadas. No entanto, a produção fotossintética de hidrogênio é limitada pela baixa eficiência que as bactérias apresentam na utilização da luz (Hallenbeck, 2009). Para este mesmo autor, outro problema é a concomitante produção de oxigênio no processo, visto que misturas hidrogênio/oxigênio altamente explosivas podem ser geradas, além das 
Produção de hidrogênio em reatores anaeróbios termofílicos

enzimas hidrogenases, que atuam na formação do hidrogênio serem altamente sensíveis ao oxigênio.

O uso do processo fermentativo parece ser mais promissor tecnicamente e vários trabalhos têm levantado as vantagens e desvantagens de tal tecnologia. Para Wang \& Wan (2009), as vantagens da produção por via fermentativa são: alta velocidade de produção de hidrogênio e operação simples, além da possibilidade de utilizar várias substâncias orgânicas como substratos, como o caso da utilização de águas residuárias ricas em carboidratos, as quais servirão para a produção de energia e ainda receberão tratamento parcial. Porém, entre os desafios da produção de $\mathrm{H}_{2}$ por via fermentativa ainda estão a manutenção de produção contínua e estável do $\mathrm{H}_{2}$, bem como a obtenção de altos rendimentos, próximos aos previstos estequiometricamente. Além disso, as condições ambientais e nutricionais que afetam o processo não estão totalmente definidas na literatura científica.

As condições ambientais e nutricionais nas quais o consórcio microbiano será desenvolvido podem estimular ou inibir a expressão gênica de enzimas ligadas à produção e consumo de $\mathrm{H}_{2}$, estimular o crescimento dos microrganismos, selecionar espécies, atuar na termodinâmica das reações e nas limitações à transferência de massa do sistema. Assim, estudos sobre condições nutricionais são fundamentais para entendimento e aprimoramento dos processos biológicos aplicados à produção de gás hidrogênio a partir de diversas fontes orgânicas, ainda mais quando resíduos ou despejos de um processo produtivo são utilizados, devido à variabilidade da composição da matéria-prima. Entre os fatores que determinam as condições ambientais impostas aos microrganismos estão o tipo de reator e o tempo de detenção hidráulica (TDH) aplicado a ele, pois definem a forma de crescimento da biomassa (disperso ou aderido), intensidade de mistura e contato entre biomassa, substrato e os produtos da fermentação. Portanto, estudos comparativos entre diferentes configurações de reatores, nos quais o substrato e demais fatores ambientais sejam os mesmos, são imprescindíveis para a melhoria do processo fermentativo visando à produção de hidrogênio.

Muitos pesquisadores tem se dedicado a avaliar tais condições quando águas residuárias são usadas e muitos avanços foram conseguidos nos últimos anos. No entanto, pesquisas nessa direção com aplicação de condições termofílicas são 
escassas na literatura, principalmente porque as águas residuárias são geralmente lançadas em temperaturas menores que $40^{\circ} \mathrm{C}$. Alguns despejos, entretanto, são lançados a altas temperaturas, como a vinhaça gerada na etapa de destilação na produção do bioetanol, e os processos termofílicos poderiam ser aplicados nesses casos, justificando estudos fundamentais nessa área.

Assim, considerando a escassez de dados na literatura sobre processos anaeróbios termofílicos aplicados à produção de hidrogênio, esta pesquisa avaliou a operação de reatores acidogênicos à temperatura termofílica, buscando uma configuração de reator eficiente e condições nutricionais adequadas para viabilizar a produção de $\mathrm{H}_{2}$. 


\section{OBJetivos}

\subsection{Objetivo Geral}

O objetivo principal desse projeto foi avaliar as condições de operação para produção de hidrogênio em reatores anaeróbios termofílicos $\left(55^{\circ} \mathrm{C}\right)$, com vistas a obter subsídios técnicos para indicar a configuração de reator mais adequada, entre o reator tubular, com e sem leito empacotado, e o reator de manta de lodo e escoamento ascendente (UASB).

\subsection{Objetivos Específicos}

Os objetivos específicos do projeto foram:

- Avaliar a influência da configuração do reator no rendimento e na produção de hidrogênio, operando reatores UASB e tubular com e sem material suporte, todos operando a $55^{\circ} \mathrm{C}$;

- Analisar os efeitos da configuração do reator e tempo de detenção hidráulica (TDH) nas rotas metabólicas estabelecidas no sistema;

- Estabelecer os melhores TDH e carga orgânica volumétrica (COV) para operação de cada reator;

- Testar diferentes concentrações de micronutrientes (Fe, Ni, Mg, Co, Se, $Z n$ ) e macronutrientes ( $P, N)$, determinando a composição capaz de melhorar a atividade das bactérias fermentativas produtoras de hidrogênio 


\section{REVISÃo BIBLIOGRÁFICA}

\subsection{Rotas metabólicas de produção de hidrogênio por via anaeróbia fermentativa}

Um rendimento teórico de $8 \mathrm{molH}_{2}$. sacarose ${ }^{-1}$ pode ser obtido pela via fermentativa anaeróbia, assumindo que carreadores comuns de elétrons, como $\mathrm{NADH}$, ferrodoxina reduzida e formiato, realizam a transferência de elétrons aos prótons (Thauer, Jungermann, \& Decker, 1977). Contudo, o processo de fermentação anaeróbia pode gerar diferentes rendimentos de $\mathrm{H}_{2}\left(\mathrm{YH}_{2}\right)$, dependendo do substrato e da rota metabólica desenvolvida pelo consórcio microbiano. Após hidrólise dos carboidratos, segue-se a glicólise dos monossacarídeos, que pode render 4 mols de NADH, no caso da sacarose (formada por uma molécula de glicose e uma de frutose) como substrato (Equação 1). O piruvato resultante pode ser utilizado pelos microrganismos na maioria das vezes através da rota lise piruvato:formiato (PFL - pyruvate:formate lyase) (Equações 2-3) e/ou piruvato:ferrodoxina oxidoredutase (PFOR - pyruvate: ferredoxin oxidoreductase) (Equações 4-5) para produzir $\mathrm{H}_{2}$. Assim, essas etapas podem resultar em 4 mols de $\mathrm{H}_{2}$ quando a NADH é oxidada pelo NADH:ferrodoxina oxidoredutase (NFOR - NADH: ferredoxin oxidoreductase) (Equação 6), pela redução direta pela hidrogenase (Equação 7) ou outra rota, mais 4 mols gerados pela produção de Acetil-CoA, se o ácido acético for o produto final (Equação 8) (Hallenbeck, Abo-Hashesh, \& Ghosh, 2012; Cai, Jin, Monis, \& Saint, 2011; Sinha \& Pandey, 2011).

Glicólise

$$
\mathrm{C}_{12} \mathrm{H}_{22} \mathrm{O}_{11}+4 \mathrm{NAD}^{+} \mathrm{H}_{2} \mathrm{O} \rightarrow 4 \mathrm{CH}_{3} \mathrm{COCOOH}+4 \mathrm{NADH}+4 \mathrm{H}^{+} \text {Equação } 1
$$


Rota metabólica PFL

$$
\begin{aligned}
\mathrm{CH}_{3} \mathrm{COCOOH}+\mathrm{CoASH} & \rightarrow \mathrm{CH}_{3} \mathrm{COSCoA}+\mathrm{HCOOH} \text { Equação } 2 \\
\mathrm{HCOOH} & \rightarrow \mathrm{H}_{2}+\mathrm{CO}_{2} \text { Equação } 3
\end{aligned}
$$

Rota metabólica PFOR

$$
\begin{gathered}
\mathrm{CH}_{3} \mathrm{COCOOH}+\mathrm{CoASH}+\mathrm{Fd} \rightarrow \mathrm{CH}_{3} \mathrm{COSCoA}+\mathrm{FdH}_{2}+\mathrm{CO}_{2} \text { Equação } 4 \\
\mathrm{FdH}_{2} \stackrel{\mathrm{H}_{2} a s e}{\longrightarrow} \mathrm{H}_{2}+\mathrm{Fd} \text { Equação } 5
\end{gathered}
$$

Reação NFOR

$$
2 N A D H+\mathrm{Fd} \rightarrow 2 N A D^{+}+\mathrm{Fd} H_{2} \text { Equação } 6
$$

Oxidação direta por hidrogenase

$$
N A D H+H^{+} \stackrel{H_{2} a s e}{\longrightarrow} N A D^{+}+H_{2} \text { Equação } 7
$$

Ácido acético via Acetyl-CoA

$$
\mathrm{CH}_{3} \mathrm{COSCOA}+\mathrm{H}_{2} \mathrm{O} \rightarrow \mathrm{CH}_{3} \mathrm{COOH}+\mathrm{CoASH} \text { Equação } 8
$$

A rota via PFL é comumente associada a microrganismos facultativos, enquanto que a PFOR é encontrada na maioria dos anaeróbios estritos (Cai, Jin, Monis, \& Saint, 2011). Microrganismos que não possuem a rota PFOR são incapazes de liberar o hidrogênio da NADH na forma molecular $\left(\mathrm{H}_{2}\right)$ via NFOR, sendo necessária sua a oxidação à $\mathrm{NAD}^{+}$por meio da produção de produtos metabólicos como ácido butírico (Equação 9), propiônico (Equação 10) e etanol (Equação 11) (N. Ren, Li, Li, Wang, \& Liu, 2006; Tanisho \& Ishiwata, 1995). 
Ácido butirico via Acetyl-CoA

$2 \mathrm{CH}_{3} \mathrm{COSCOA}+2 \mathrm{NADH}+2 \mathrm{H}^{+} \rightarrow \mathrm{CH}_{3}\left(\mathrm{CH}_{2}\right)_{2} \mathrm{COOH}+2 \mathrm{NAD}^{+}+2 \mathrm{CoASH}$ Equação 9

Ácido propiônico via piruvato

$$
\mathrm{CH}_{3} \mathrm{COCOOH}+2 \mathrm{NADH}+2 \mathrm{H}^{+} \rightarrow \mathrm{CH}_{3} \mathrm{CH}_{2} \mathrm{COOH}+2 \mathrm{NAD}^{+}+\mathrm{H}_{2} \mathrm{O} \text { Equação } 10
$$

Etanol via Acetyl-CoA

$$
\mathrm{CH}_{3} \mathrm{COSCOA}+2 \mathrm{NADH}+2 \mathrm{H}^{+} \rightarrow \mathrm{CH}_{3} \mathrm{CH}_{2} \mathrm{OH}+2 \mathrm{NAD}^{+}+\mathrm{CoASH} \text { Equação } 11
$$

\subsection{Influência da temperatura no processo fermentativo}

$\mathrm{Na}$ prática, os baixos $\mathrm{YH}_{2}$ obtidos através da fermentação estão também associados ao fato da formação de $\mathrm{H}_{2}$ catalisada pela hidrogenase ser afetada pelo tipo de carreador intracelular de elétrons e poder ser interrompida pelo acúmulo de $\mathrm{H}_{2}$ (Chou, Jenney, Adams, \& Kelly, 2008). Segundo Angenent, Karim, Al-Dahhan, Wrenn, \& Domíguez-Espinosa (2004), a produção de hidrogênio utilizando ferrodoxina continua enquanto a pressão parcial de hidrogênio se mantiver inferior a $0,3 \mathrm{~atm}$; para a NADH o valor deve ser inferior a $0,6 \times 10^{-4} \mathrm{~atm}$. Como a solubilidade do $\mathrm{H}_{2}$ é inversamente proporcional à temperatura, sistemas operados na faixa termofílica $\left(40\right.$ à $\left.60^{\circ} \mathrm{C}\right)$ permitem maior transferência do $\mathrm{H}_{2}$ para o biogás que aqueles trabalhando em temperaturas mesofílicas $\left(25\right.$ à $\left.40^{\circ} \mathrm{C}\right)$. Contudo, conforme apontado por Sinha \& Pandey (2011), o aumento da temperatura de conversão da glicose altera a constante de equilíbrio da reação levando ao aumento da concentração de $\mathrm{H}_{2}$ na fase líquida. Portanto, o aumento da temperatura pode melhorar a produção de $\mathrm{H}_{2}$ se o sistema permitir a transferência do $\mathrm{H}_{2}$ adicional para biogás.

Kongjan, Min, \& Angelidaki (2009) afirmam que a utilização da temperatura termofílica extrema $\left(70^{\circ} \mathrm{C}\right)$ para a fermentação de hemicelulose hidrolisada por cultura mista favoreceu a produção de hidrogênio via rota do acetato. Para esses 
autores, o resultado se deve às melhores condições termodinâmicas e maior tolerância dos microrganismos termofílicos à alta pressão parcial de hidrogênio.

Testando diferentes temperaturas de operação $\left(20,37\right.$ e $\left.55^{\circ} \mathrm{C}\right)$ em reatores de mistura contínuos, Karlsson, Vallin, \& Ejlertsson (2008) obtiveram melhor rendimento a $55^{\circ} \mathrm{C}$, porém, a maior velocidade de produção ocorreu a $37^{\circ} \mathrm{C}$.

Além disso, trabalhando à temperatura de $55^{\circ} \mathrm{C}$, Luo, Karakashev, Xie, Zhou, \& Angelidaki (2011) verificaram a inibição da homoacetogênese em ensaios em batelada utilizando substrato sintético à base de glicose. A homoacetogênese é uma rota de consumo de $\mathrm{H}_{2}$ e produção de ácido acético (Equação 12) utilizada por microrganismos hidrogenotróficos facultativos, que podem crescer heterotroficamente, utilizando substratos orgânicos como açúcares, álcoois e alguns ácidos orgânicos, ou autotroficamente a base de $\mathrm{H}_{2}, \mathrm{CO}_{2}$ ou $\mathrm{CO}$ (Saady, 2013). Porém, ainda há muitas incertezas sobre os fatores que levam à mudança de rota metabólica dos microrganismos homoacetogênicos e que determinam sua dominância dentro do consórcio microbiano. Diminuição da relação substrato/ microrganismo, aumento da pressão parcial de $\mathrm{H}_{2}$ e deficiências nutricionais são algumas das hipóteses (Saady, 2013). Assim, o menor requerimento de substrato para o crescimento de microrganismos termofílicos em relação aos mesofílicos e as diferenças entre as espécies adaptadas a cada faixa de temperatura, podem minimizar a ocorrência de homoacetogênese, permitindo produção contínua e mais estável do gás hidrogênio.

$$
2 \mathrm{CO}_{2}+4 \mathrm{H}_{2} \rightarrow \mathrm{CH}_{3} \mathrm{COOH}+2 \mathrm{H}_{2} \mathrm{O} \text { Equação } 12
$$

\subsection{Influência da configuração do reator e tempo de detenção hidráulica (TDH) na produção de $\mathrm{H}_{2}$}

A configuração do reator exerce grande influência nos processos biológicos que ocorrem em seu interior, uma vez que determina a hidrodinâmica do sistema e, assim, os processos de transferência de massa e a forma de crescimento da biomassa (suspensa, em grânulos ou aderida) no sistema. 
A maioria dos estudos voltados para a produção de $\mathrm{H}_{2}$ vem sendo realizada em reatores de mistura (em inglês continuous stirred tank reactor - CSTR), por permitir melhor contanto entre biomassa e substrato e diminuir a resistência à transferência de massa no reator, permitindo a transferência do $\mathrm{H}_{2}$ do meio líquido para gasoso. No entanto, nos reatores CSTR a biomassa fica suspensa no meio líquido e o tempo de retenção celular (TRC) é igual ao tempo de detenção hidráulica (TDH), limitando a concentração de biomassa no sistema (Wang \& Wan, 2009). Contudo, de acordo com Hawkes, Hussy, Kyazze, Dinsdale, \& Hawkes (2007), microrganismos consumidores de $\mathrm{H}_{2}$ podem ser inibidos ao se aplicar baixos tempos de detenção hidráulica (TDH) aos reatores. Dessa forma, reatores com biomassa imobilizada são uma alternativa, sejam eles com biomassa granular ou aderida ao meio suporte, pois são capazes de operar com baixos TDH, mas mantendo o TRC alto, o que permite a manutenção de biomassa acidogênica especializada.

Babu, Mohan, \& Sarma (2009) encontraram resultados superiores de produção de $\mathrm{H}_{2}$ em reatores com biofilme, se comparados com reatores de crescimento disperso. Show et al. (2010), estudando reatores com células imobilizadas e suspensas, obtiveram melhores resultados para a produção de $\mathrm{H}_{2}$ utilizando processo com lodo granular. Entre os reatores com biomassa imobilizada mais comuns estão os reatores de leito empacotado e o UASB.

Os reatores de leito empacotado (também chamados leito fixo), com partículas biocatalíticas imobilizadas, têm sido largamente usados pela indústria. Por exemplo, enzimas imobilizadas são utilizadas para a isomerização da glicose nesse tipo de reator, os quais também são utilizados para a hidrólise seletiva da penicilina (Bailey \& Ollis, 1986).

Uma forma primitiva de reator de leito fixo foi descrita por Young \& McCarty (1969) para a produção de metano por substrato sintético à base de carboidratos e proteínas, utilizando rochas como suporte de biomassa. Esses reatores, denominados originalmente de filtros anaeróbios, são geralmente tratados com o modelo de escoamento pistonado e, nas configurações mais comuns para o tratamento de efluentes, partículas suporte inertes são adicionadas ao reator e a biomassa adere por meio da formação de biofilmes. O material, o formato e tamanho das partículas interferem na área superficial disponível para a aderência microbiana 
Produção de hidrogênio em reatores anaeróbios termofílicos

e no escoamento do fluido entre as partículas, podendo levar à formação de caminhos preferenciais e pequenas zonas de recirculação interna.

Reatores UASB são amplamente conhecidos por permitirem a auto imobilização dos microrganismos através formação de lodo granular, resultando em um sistema robusto de tratamento para efluentes com alta carga orgânica, que permite operações com baixo TDH e alto TRC. Sistemas de tratamento utilizando reatores UASB em duas fases, ou seja, acoplando um reator para acidogênese e um segundo para metanogênese, têm sido utilizados para garantir a manutenção das condições ambientais específicas para cada comunidade microbiana (Fox \& Pohland, 1994).

No entanto, o enfoque na produção de metano deixou uma lacuna no conhecimento sobre o desempenho de reatores de leito empacotado e UASB na produção de $\mathrm{H}_{2}$ e os efeitos das condições operacionais em sua eficiência, principalmente quando se trata de operação sob condição termofílica.

Para adquirir esse conhecimento, alguns estudos utilizando reatores UASB para a produção de $\mathrm{H}_{2}$ foram desenvolvidos nos últimos anos, contudo ainda são poucos e apresentam divergências para consolidar os resultados. Gavala, Skiadas, \& Ahring (2006), operando reator UASB a $35^{\circ} \mathrm{C}$, não encontraram diferença significativa no rendimento de $\mathrm{H}_{2}\left(\mathrm{YH}_{2}\right)\left(0.7 \mathrm{molH}_{2}\right.$-mol-sac $\left.{ }^{-1}\right)$ quando submeteram o reator a TDH de 12 a 2 h, utilizando glicose como substrato. Yu \& Mu (2006), operando UASB alimentado com substrato à base de sacarose, observaram aumento no $\mathrm{YH}_{2}$ ao aumentar o TDH de $3 \mathrm{~h}$ para $14 \mathrm{~h}$, atingindo a valor máximo de

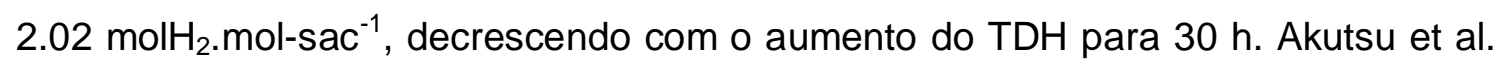
(2009), notaram efeito negativo na produção de $\mathrm{H}_{2}$ ao impor decréscimo gradual do TDH de $48 \mathrm{~h}$ para $3 \mathrm{~h}$ ao reator UASB alimentado com amido e operando a $55^{\circ} \mathrm{C}$,

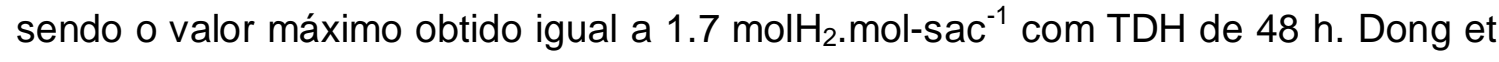
al. (2011), alimentando reator UASB termofílico $\left(55^{\circ} \mathrm{C}\right)$ com substrato à base de sacarose, variaram o TDH entre 50 e $12 \mathrm{~h}$ e obtiveram apenas uma pequena flutuação nos valores de $\mathrm{YH}_{2}\left(2.42\right.$ a $3.06 \mathrm{molH}_{2}$. mol-suc $\left.{ }^{-1}\right)$. Jung, Kim, Lee, \& Shin (2012) variando o TDH do reator UASB entre $12 \mathrm{~h} \mathrm{e} 2 \mathrm{~h}$, para a produção de $\mathrm{H}_{2}$ a partir de efluente de fábrica de café a $55^{\circ} \mathrm{C}$, encontraram $\mathrm{YH}_{2}$ máximo de (4.96 molH $_{2}$. ol-suc $^{-1}$ ) com TDH de 6 h. 
Em relação aos reatores de leito empacotado, embora estudos em temperatura mesofílica tenham apresentado a viabilidade do uso desta configuração (Chang, Lee, \& Lin, 2002), tem sido observada a queda na produção de $\mathrm{H}_{2}$ após períodos que variam de 15 a 23 dias de operação (Fernandes et al., 2013; Lima, Moreira, \& Zaiat, 2013; Penteado, Lazaro, Sakamoto, \& Zaiat, 2013; Lima \& Zaiat, 2012). A possível causa apontada seria a presença de microrganismos consumidores de $\mathrm{H}_{2}$ e/ou mudança de rota metabólica da própria comunidade produtora de $\mathrm{H}_{2}$ devido à diminuição do substrato disponível (relação substrato/microrganismos).

Kongjan \& Angelidaki (2010), realizaram estudo comparativo entre as configurações UASB e filtro anaeróbio com suporte plástico, operados à $70^{\circ} \mathrm{C}$, para produção de hidrogênio a partir de hemicelulose hidrolisada. Utilizando TDH de $24 \mathrm{~h}$ e 12 h, e COV de 3,9 e 7,8 g-açúcar. $h^{-1} \cdot L^{-1}$, a operação com TDH de 24 h e 3,9 gaçúcar. $\mathrm{h}^{-1} \cdot \mathrm{L}^{-1}$ foi a mais adequada e o reator UASB apresentou os melhores resultados de produção de $\mathrm{H}_{2}\left(821,4 \pm 24,1 \mathrm{~mL}-\mathrm{H}_{2} \cdot \mathrm{d}^{-1} \cdot \mathrm{L}^{-1}\right.$ e 212,0 $\pm 24,1 \mathrm{~mL}-\mathrm{H}_{2} \cdot \mathrm{g}-$ açúcar $^{-1}$ ). Porém, poucos estudos foram realizados comparando reatores UASB e de leito empacotado e, uma vez que o substrato, a temperatura de operação, pH inicial afetam a produção de $\mathrm{H}_{2}$, mais estudos devem ser realizados visando a comparação entre as configurações, sob as mesmas condições operacionais, para apontar a mais adequada.

\subsection{Efeito das condições nutricionais para a produção de $\mathbf{H}_{2}$}

Compreender as necessidades de macro e micronutrientes das bactérias produtoras de hidrogênio, relacionadas algumas vezes com as atividades enzimáticas, também tem sido o foco de muitos estudos, como abordado a seguir. No entanto, os resultados divergem bastante e os testes são desenvolvidos, em sua maioria, em batelada e condições mesofílicas.

Lee, Miyahara, \& Noike (2001) realizaram testes em batelada com temperatura mesofílica $\left(37^{\circ} \mathrm{C}\right)$, para verificar o efeito do ferro nas atividades das bactérias produtoras de $\mathrm{H}_{2}$. Os pesquisadores variaram a concentração de $\mathrm{Fe}_{2}{ }^{+}$de 0 a $1762,4 \mathrm{mg} \cdot \mathrm{L}^{-1}$, e encontraram o melhor rendimento com 352,8 $\mathrm{mg} \mathrm{Fe}_{2}{ }^{+} \cdot \mathrm{L}^{-1}$, porém a máxima produção de hidrogênio ocorreu quando utilizado 1762,4 mg Fe ${ }_{2}{ }^{+} \cdot \mathrm{L}^{-1}$. 
Produção de hidrogênio em reatores anaeróbios termofílicos

Em teste em batelada, utilizando glicose a $35^{\circ} \mathrm{C}$, Wang \& Wan, (2008a) variaram a concentração de $\mathrm{Fe}_{2}{ }^{+}$no meio entre 0 e $15000 \mathrm{mg} \cdot \mathrm{L}^{-1}$. Nas concentrações de 300 e $350 \mathrm{mgFe}{ }^{+} \cdot L^{-1}$, a presença de $\mathrm{Fe}_{2}{ }^{+}$foi capaz de aumentar a produção de $\mathrm{H}_{2}$ em 55,7\% e seu rendimento em 58,3\% (2,22 $\mathrm{molH}_{2}$. mol- glic $\left.^{-1}\right)$, respectivamente. No entanto, concentrações maiores causaram o declínio na produção de hidrogênio. Segundo esses autores, isso pode ser explicado pelo ferro ser fundamental para a produção do carregador de elétrons ferrodoxina nas hidrogenases, assim, em faixa de concentração apropriada, o $\mathrm{Fe}_{2}{ }^{+}$pode aumentar a atividade das hidrogenases.

Para encontrar a composição de nutrientes mais adequada para a produção de hidrogênio, Lin \& Lay (2005) realizaram testes em batelada a $35^{\circ} \mathrm{C}$. Esses autores observaram que os nutrientes que mais afetam a biomassa nessas condições são o magnésio, sódio, zinco e ferro. Assim, os mesmos aplicaram o método Taguchi aos dados e encontraram a composição otimizada para os nutrientes principais (em mg. ${ }^{-1}: 120 \mathrm{MgCl}_{2} \cdot 6 \mathrm{H}_{2} \mathrm{O}, 1000 \mathrm{NaCl}, 0.5 \mathrm{ZnCl}_{2}$ e 3 $\mathrm{FeSO}_{4} .7 \mathrm{H}_{2} \mathrm{O}$ ), a qual aumentou o rendimento, a velocidade de produção e a porcentagem de hidrogênio no biogás em $30 \%, 66 \%$ e $66 \%$, respectivamente.

Xiaolong, Minghua, Hanqing, Qinqin, \& Lecheng (2006) realizaram testes em batelada, na temperatura mesofílica $\left(37^{\circ} \mathrm{C}\right)$, com lodo de reator UASB tratando efluentes ácidos. Variando a concentração de íons de sódio entre 0 e $16 \mathrm{~g} \cdot \mathrm{L}^{-1}$, os autores observaram as melhores velocidades de degradação de sacarose e produção de hidrogênio na faixa de 1 a $2 \mathrm{~g} \mathrm{Na}^{+2} \cdot \mathrm{L}^{-1}$. Os autores afirmam, ainda, que em menores concentrações, a quantidade de íons de sódio disponível no meio pode não ser suficiente para o crescimento das bactérias produtoras de hidrogênio, e em excesso, porém, a atividade enzimática desses microrganismos é afetada.

Wang \& Wan (2008) verificaram que à temperatura de $35^{\circ} \mathrm{C}, \mathrm{Ni}_{2}{ }^{+}$na concentração $0,1 \mathrm{mg} \cdot \mathrm{L}^{-1}$ pode melhorar o rendimento do hidrogênio, alcançando $2,38 \mathrm{~mol} \mathrm{de} \mathrm{H}_{2} / \mathrm{mol}$ de glicose. Entretanto, em concentrações da ordem de 20 a 50 $\mathrm{mgNi}_{2}{ }^{+} \cdot L^{-1}$, o rendimento chega a ser menor que na ausência desse metal.

Othong, Poonsuk, Intrasungkha, Dhamwichukorn, \& Birkeland (2008), verificaram significante relação entre a concentração de ferro e a razão $\mathrm{C} / \mathrm{N}$. Em 
testes em batelada com efluente de fábrica de óleo de palma a $60^{\circ} \mathrm{C}$, esses autores encontraram que as concentrações que permitiam a máxima produção de hidrogênio (6,5 $\mathrm{LH}_{2} / \mathrm{L}$ efluente) com maior eficiência na remoção de DQO (58\%) são: $257 \mathrm{mg}$ $\mathrm{Fe}^{+2} \cdot \mathrm{L}^{-1}$, razão $\mathrm{C} / \mathrm{N}$ de 74 e $\mathrm{C} / \mathrm{P}$ de 559 . Em teste em batelada mesofílica $\left(35^{\circ} \mathrm{C}\right)$, Lin \& Lay (2004) encontraram que a razão $\mathrm{C} / \mathrm{N}$ de 47 era a que permitia 0 melhor rendimento de $\mathrm{H}_{2}\left(4,8 \mathrm{~mol} \mathrm{H}_{2} / \mathrm{mol}\right.$ sacarose $)$.

Em experimentos em batelada a $35^{\circ} \mathrm{C}$, Liu et al. (2011) testaram o uso de lixiviado de uma unidade de compostagem como complementação nutricional para a produção de $\mathrm{H}_{2}$ utilizando glicose e efluente de indústria de sucos. Os autores demonstraram que a produção de $\mathrm{H}_{2}$ pode ser melhorada quando há a cofermentação do efluente com o lixiviado, tornando-se uma alternativa de baixo custo para adequar o efluente tratado às necessidades nutricionais do consórcio microbiano em relação ao nitrogênio e os outros micronutrientes.

Assim, uma abordagem possível para melhorar a produção de hidrogênio e seu rendimento seria a operação de reatores em fluxo contínuo, associando a otimização dos nutrientes que, como mostra a literatura, exercem grande influência sobre a atividade da biomassa. Além disso, a operação à temperatura termofílica $\left(55^{\circ} \mathrm{C}\right)$ pode selecionar populações microbianas que, nessas condições, apresentem a via da produção de acetato como preferencial e superem as limitações termodinâmicas. $O$ tratamento termofílico tem, ainda, a vantagem de reduzir custos de resfriamento de efluentes lançados a altas temperaturas, como o caso da vinhaça (gerada na produção de etanol), efluentes de fábricas de celulose e papel e produtoras de óleo de palma, entre outros. 


\section{Materials e MÉtodos}

\subsection{Etapas experimentais}

A pesquisa foi realizada em duas etapas. A primeira contou com operação de reatores anaeróbio ascendente de manta de lodo (UASB - upflow anaerobic sludge blanket), tubular com leito empacotado (TCS - tubular com suporte) e tubular sem material suporte (TSS - tubular sem suporte), alimentados continuamente sob diferentes tempos de detenção hidráulica (TDH), para avaliar a influência do tipo de reator e TDH na produção de $\mathrm{H}_{2}$. A segunda etapa foi realizada em batelada para verificar a influência de micro e macronutrientes na produção de $\mathrm{H}_{2}$ e encontrar a condição nutricional ótima.

\subsection{Reatores}

Os reatores tubular, com fluxo ascendente (Figura 1), e UASB (upflow anaerobic sludge blanket) (Figura 2) foram projetados em escala de bancada com volumes úteis aproximados de 3,8 L e 3,6 L, respectivamente. 


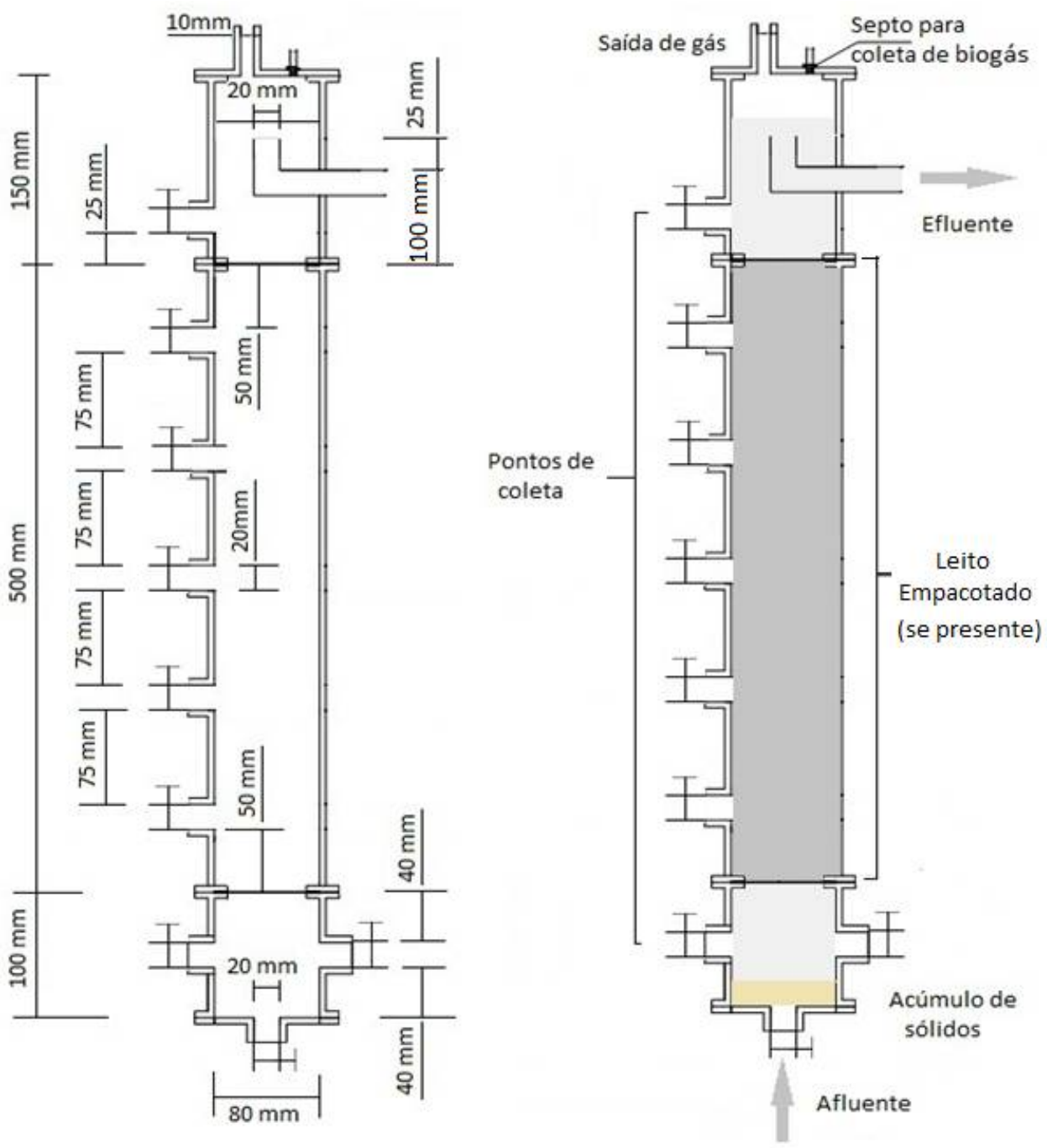

Figura 1 - Dimensões e esquema do reator tubular.

O reator tubular era composto por três compartimentos: 1 - entrada de afluente e acúmulo de sólidos, 2- leito fixo, delimitado por grades de inox com malha de 0,2 $\mathrm{cm}$ que apoiam o material suporte e 3- headspace e saída do efluente. 

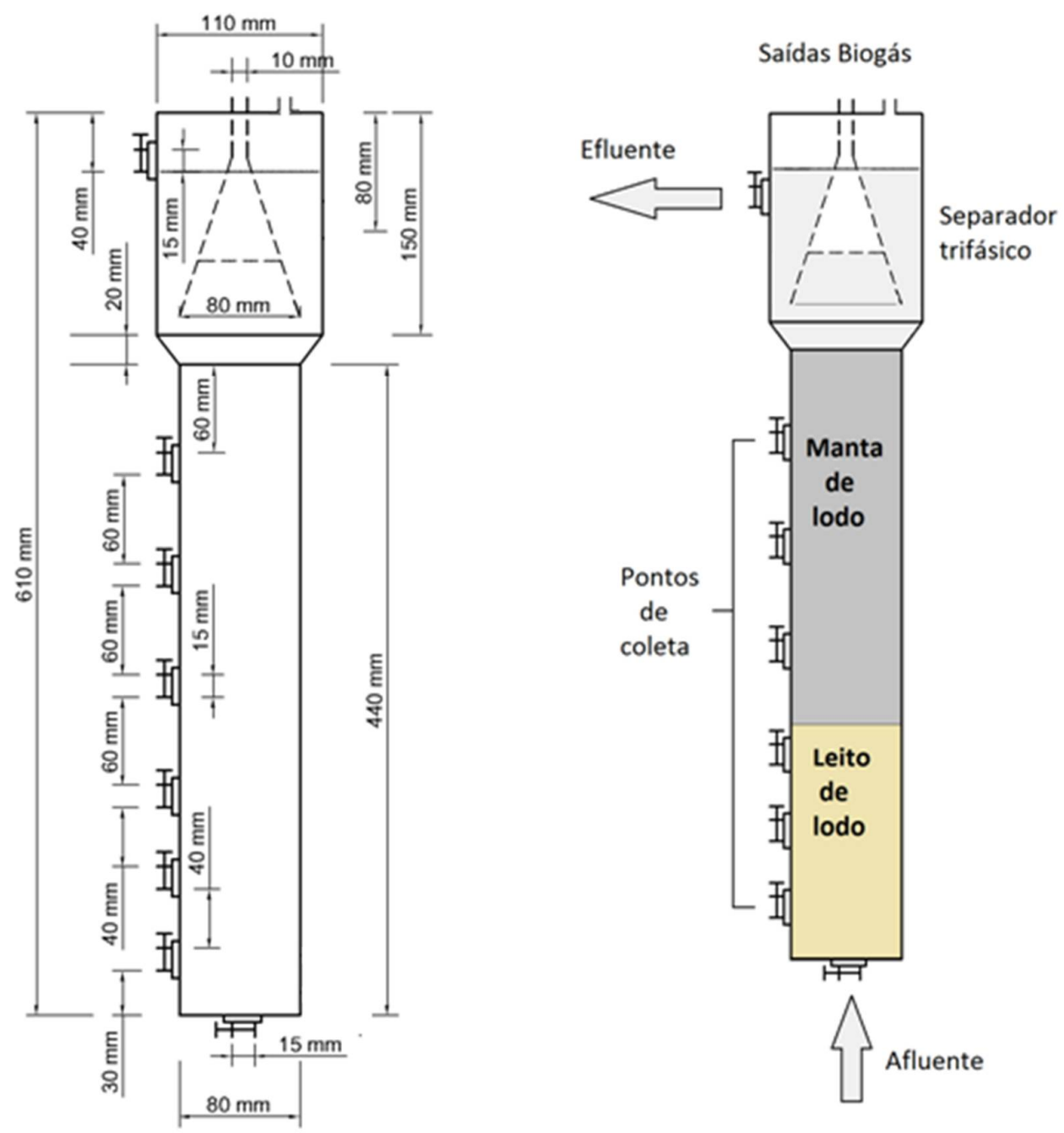

Figura 2 - Dimensões e esquema do reator UASB.

O reator UASB apresentava igualmente três compartimentos, a saber: 1entrada do afluente e leito de lodo, 2- manta de lodo e 3- separador trifásico, em formato de funil invertido, e saída do efluente. Para evitar a perda de biogás, a saída do efluente em ambos os reatores ocorria através de conduto afogado. $O$ reator UASB possuía, ainda, duas saídas de biogás, uma para a coleta na parte interna do separador trifásico e outra na parte externa.

Havia 6 pontos de amostragem ao longo dos reatores, além de suas saídas convencionais. O reator de leito fixo possuía um ponto de amostragem no compartimento de entrada e 5 ao longo do leito, e o reator UASB possuía 3 pontos no leito de lodo e 3 na manta de lodo. 


\subsection{Substrato Sintético}

O substrato utilizado era composto por sacarose $\left(1781,24 \mathrm{mg} \cdot \mathrm{L}^{-1}\right)$, ureia $\left(11,51 \mathrm{mg} \cdot \mathrm{L}^{-1}\right)$, bicarbonato $\left(500 \mathrm{mg} \cdot \mathrm{L}^{-1}\right)$ e solução padrão de nutrientes $\left(0,25 \mathrm{~mL} \cdot \mathrm{L}^{-1}\right)$. A solução padrão de nutrientes conforme (Del Nery, 1987) e continha (g.L ${ }^{-1}$ ): $\mathrm{NiSO}_{4} \times 6 \mathrm{H}_{2} \mathrm{O}, 2,00 ; \mathrm{FeSO}_{4} \times 7 \mathrm{H}_{2} \mathrm{O}, 10,00 ; \mathrm{FeCl}_{3} \times 6 \mathrm{H}_{2} \mathrm{O}, 1,00 ; \mathrm{CoC1}_{2} \times 2 \mathrm{H}_{2} \mathrm{O}, 0,16$; $\mathrm{CaC1}_{2} \times 2 \mathrm{H}_{2} \mathrm{O}, 8,24 ; \mathrm{KH}_{2} \mathrm{PO}_{4}, 21,44 ; \mathrm{K}_{2} \mathrm{HPO}_{4}, 5,20 ; \mathrm{Na}_{2} \mathrm{HPO}_{4} .2 \mathrm{H}_{2} \mathrm{O}, 11,04 ; \mathrm{SeO}_{2}$,

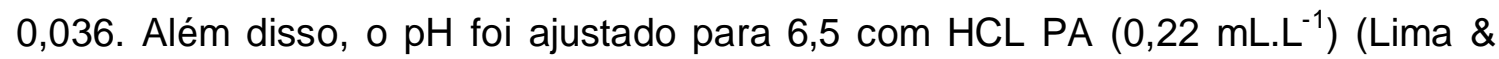
Zaiat, 2012).

\subsection{Material suporte}

O material suporte utilizado no reator tubular com leito empacotado eram aparas de polietileno de baixa densidade, cedidas pela empresa Interplás, sediada em São Carlos. As aparas foram retiradas durante a limpeza das máquinas que fazem a extrusão do plástico obtido da reciclagem e produzem os fios de polietileno que, posteriormente, são cortados para servirem de matéria-prima na produção de sacos plásticos.

\subsubsection{Granulometria do material suporte}

Após a obtenção do material, o mesmo foi cortado e sua granulometria é apresentada na Figura 3. 


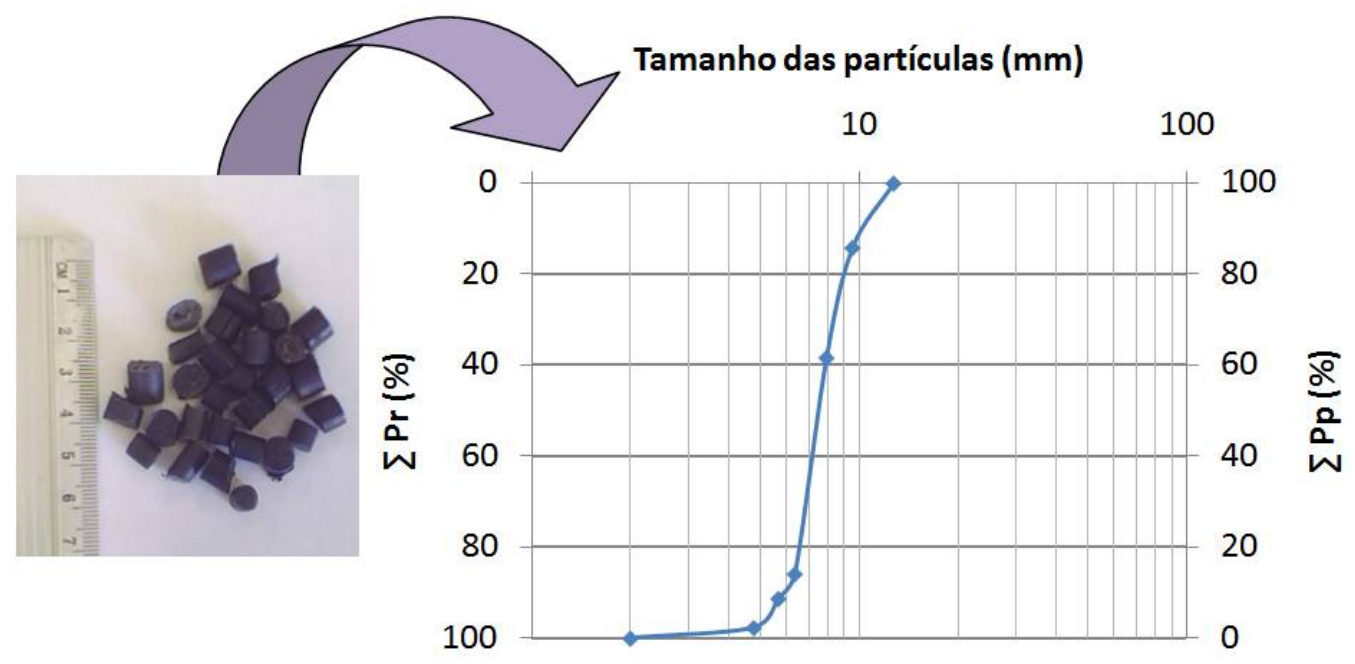

Figura 3 - Material suporte cortado e gráfico de sua granulometria.

O ensaio granulométrico foi realizado no Departamento de Geotecnia da EESC - USP. Após seco em estufa de $100^{\circ} \mathrm{C}$, o material foi homogeneizado e quarteado manualmente para redução da amostra. Para o peneiramento, realizado através de processo mecânico por 15 minutos, foi utilizado $1 / 8$ do material de preenchimento do leito do reator. Assim, conforme os resultados do ensaio, $72 \%$ do material componente do leito apresenta dimensão inferior a $9,52 \mathrm{~mm}$ e superior a $6,35 \mathrm{~mm}$.

\subsection{2. Índice de vazios}

Para a determinação do índice de vazios do leito fixo do reator tubular foi utilizada a Equação 13. Assim, a fim de encontrar o volume do leito vazio $\left(\mathrm{V}_{\mathrm{VV}}\right)$, o volume útil total do reator sem o material suporte foi medido e foram descontados os volumes dos compartimentos $\left(V_{c}\right)$ de entrada e saída, dados pela Equação 14, na qual $h_{c}$ é a altura de cada compartimento e $D$, o diâmetro do reator.

$$
\begin{gathered}
i v_{L}(\%)=\frac{V_{l p}}{V_{l v}} \times 100 \text { Equação } 13 \\
V_{C}=\pi \times \frac{D^{2}}{4} \times h_{c} \text { Equação } 14
\end{gathered}
$$


Após a disposição do material suporte no interior do reator, o volume útil total do reator foi novamente medido e, descontados os volumes dos compartimentos de entrada e saída, obteve-se o volume do leito preenchido $\left(\mathrm{V}_{\mathrm{lp}}\right)$. Os valores encontrados para os volumes do leito fixo vazio e preenchido foram 2,58 $\mathrm{L}$ e 1,03 $\mathrm{L}$, respectivamente, e 40\% para o índice de vazios do leito.

\subsection{Inoculação dos reatores}

O método de auto inoculação foi aplicado ao reator tubular, o qual consiste em recircular por 5 dias meio sintético, previamente fermentado em recipiente aberto por 3 dias (Leite, Fernandes, Pozzi, Barboza, \& Zaiat, 2008). O reator UASB, por sua vez, teve um terço de seu volume preenchido com lodo proveniente de reator UASB metanogênico termofílico, que trata a vinhaça da usina de açúcar e álcool São Martinho (Pradópolis, SP). O inóculo passou por pré-tratamento térmico a $100^{\circ} \mathrm{C}$ por 15 minutos (Hawkes, 2002) antes de ser colocado no reator. Em seguida, aplicou-se a recirculação por 5 dias de meio fermentado. Dessa maneira, pretendeu-se adaptar o lodo do reator UASB e estimular o crescimento de bactérias acidogênicas no interior dos reatores, as quais estão naturalmente presentes no ar.

\subsection{Protocolo experimental da etapa 1 - Operação de reatores contínuos}

Nessa fase, os reatores TCS, TSS e UASB foram operados variando o tempo de detenção hidráulica (TDH) e, consequentemente, a carga orgânica volumétrica (COV) aplicada, conforme a Tabela 1. 
Tabela 1 - Condições de operação dos reatores na fase 1.

\begin{tabular}{|c|c|c|c|c|c|}
\hline Sigla & Reator & TDH (h) & $\begin{array}{c}\text { COV } \\
\left(g D Q O . L^{-1} \cdot d^{-1}\right)\end{array}$ & $\begin{array}{c}V_{\text {asc }}{ }^{(a)} \\
\left(\mathrm{cm}^{-1} \mathrm{~h}^{-1}\right)\end{array}$ & $\begin{array}{c}\text { Duração } \\
\text { (dias) }\end{array}$ \\
\hline $\mathrm{USU}^{(\mathrm{b})}$ & & 12 & 4 & 4,8 & 57 \\
\hline U12 & & 12 & 4 & 4,8 & 154 \\
\hline U6 & UASB & 6 & 8 & 9,5 & 71 \\
\hline U2 & & 2 & 24 & 28,5 & 84 \\
\hline TCS2 & TCC & 2 & 24 & 20,7 & 139 \\
\hline TCS0,5 & $1 \mathrm{CS}$ & 0,5 & 96 & 82,8 & 64 \\
\hline TSS2 & & 2 & 24 & 37,6 & 96 \\
\hline TSSO,5 & TSS & 0,5 & 96 & 150,4 & 94 \\
\hline
\end{tabular}

(a) Velocidade ascensional do líquido.

(b) USU se refere a partida do reator UASB, definida pela presença de $\mathrm{CH}_{4}$ no biogás e até que os valores de perda de biomassa, pH e conversão de sacarose se tornassem estáveis.

Os reatores tubular e UASB foram operados em fluxo contínuo e mantidos em câmara com temperatura controlada a $55^{\circ} \mathrm{C}$ (Figura 4). A alimentação utilizada foi substrato sintético com solução de nutrientes padrão (apresentada em 4.3).

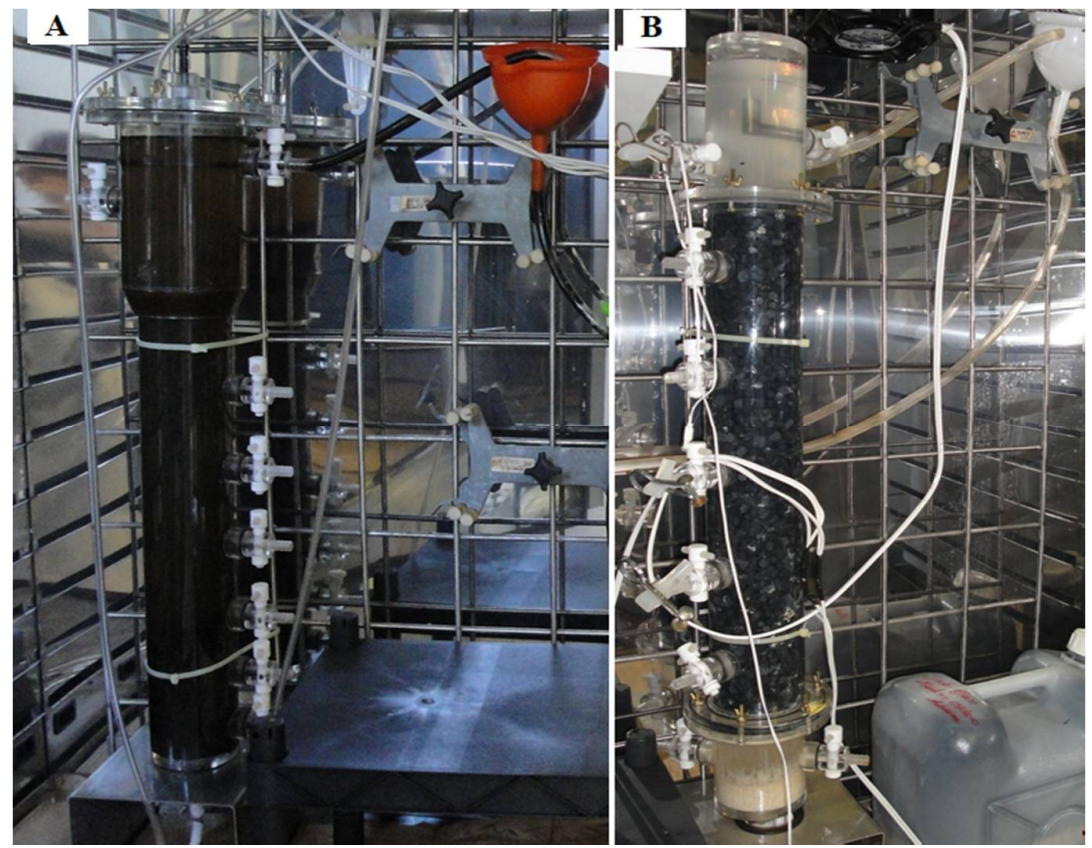

Figura 4 - Reatores operando em fluxo contínuo. A - UASB; B - leito fixo.

O monitoramento dos reatores ocorreu através das seguintes variáveis: composição e vazão do biogás; pH, DQO, sacarose, ácidos orgânicos voláteis e álcoois presentes no efluente dos reatores; além da perda de biomassa. Ao final, testes estatísticos foram aplicados aos resultados para avaliar o rendimento, a eficiência na produção de hidrogênio e composição de subprodutos gerados na 
Produção de hidrogênio em reatores anaeróbios termofílicos

condição padrão, bem como para indicar o reator e a condição mais eficiente para a produção de $\mathrm{H}_{2}$.

\subsection{Ensaios hidrodinâmicos}

O método utilizado nos ensaios hidrodinâmicos foi o de estímulo-reposta com injeção degrau (Fogler, 1999; Levenspiel, 1999), com introdução de $\mathrm{NaCl}$ (10 g.L L $^{-1}$ ) na corrente de alimentação, que nesse período era composta apenas por água de torneira. No caso do reator UASB, os ensaios para os três TDH avaliados (12, 6 e 2 horas) foram realizados após a inoculação do reator e antes da partida do reator com efluente sintético. Assim, procurou-se considerar o a influência do lodo, dotado de grânulos e materiais inertes, no escoamento do reator, evitando, contudo, que a exposição ao ambiente salino alterasse a atividade ou composição do consórcio microbiano durante as operações. Já no reator tubular, como foi adotado o procedimento de auto inoculação no início de cada operação, não havia biomassa aderida nessa etapa e os ensaios foram realizados antes das operações. Foram realizados novos ensaios ao final das etapas de operação para verificar as mudanças no escoamento decorrentes do crescimento e/ou perda de biomassa.

Para a aquisição dos dados da variação da concentração salina nos reatores, utilizou-se uma sonda de condutividade conectada à calculadora TI 89 Titanium da Texas Instruments, que por sua vez estava acoplada à interface de aquisição de dados CBL 2, da Texas Instruments. Foram coletados 600 dados durante período igual a três vezes os TDH teóricos aplicados aos reatores, representados pela razão entre o volume do reator e a vazão aplicada.

Os dados de concentração do traçador ( $\mathrm{NaCl}$ ), na injeção degrau, forneceram curvas-resposta sempre crescentes até que se atingiu a concentração de traçador aplicada. Para que fosse possível obter os parâmetros desejados, a curva de concentração do traçador em função do tempo precisou ser trabalhada. Inicialmente a curva-resposta foi normalizada, gerando a curva $F$, cujos valores foram calculados através da Equação 15 (Levenspiel, 1999). 


$$
F_{i}=\frac{C_{i}}{C_{\text {máx }}} \text { Equação } 15
$$

$\mathrm{Na}$ Equação $15, \mathrm{C}_{\mathrm{i}}$ é o valor da concentração de $\mathrm{NaCl}$ no instante i e $\mathrm{C}_{\text {máx }}$ é o valor máximo da concentração de $\mathrm{NaCl}$ detectado.

Em seguida, a curva $F$ foi ajustada para a equação sigmoide de Boltzmann, no programa Origin 8.0. Com os valores ajustados, a curva $F$ foi transformada em uma curva de distribuição de tempo de residência (DTR), a curva E, composta pelos valores das derivadas dos pontos de $\mathrm{F}$ em função do tempo (Equação 16)(Levenspiel, 1999). Assim, com os valores da curva $E$ foi possível determinar os valores de TDH médio $\left(\overline{\theta_{h}}\right)$ (Equação 17), a variância $\left(\sigma^{2}\right)$ (Equação 18) e a variância adimensional $\left(\sigma \theta^{2}\right)$ (Equação 19) (Levenspiel, 1999).

$$
\begin{gathered}
\mathrm{E}=\frac{d F}{d t} \text { Equação } 16 \\
\overline{\theta_{\mathrm{h}}}=\frac{\int_{0}^{\infty} \mathrm{tE} d t}{\int_{0}^{\infty} \mathrm{Edt}} \text { Equação } 17 \\
\sigma^{2}=\frac{\int_{0}^{\infty}\left(\mathrm{t}-\theta_{\mathrm{h}}\right)^{2} \mathrm{Edt}}{\int_{0}^{\infty} \mathrm{Edt}} \text { Equação } 18 \\
\sigma_{\theta}^{2}=\frac{\sigma^{2}}{\theta_{\mathrm{h}}^{2}} \text { Equação } 19
\end{gathered}
$$

Levenspiel (1999) apresenta o modelo de tanques em série e o modelo de dispersão longitudinal para representar o escoamento em reatores não ideais. Para esse autor, quanto maior número de reatores em tanques-em-série ( $\mathrm{N}$ - Equação 20) mais próximo o reator está do fluxo pistonado ideal. Valores de $\mathrm{N}$ a partir de 30 já permitem a modelagem do reator como pistonado. Comparando com modelo de dispersão, o coeficiente de dispersão longitudinal (D/uL - Equação 21) com tendência a zero indica que a dispersão pode ser negligenciada, assim, o modelo pistonada é adequado e valores de D/uL tendendo ao infinito, tornam o modelo de mistura completa mais apropriado para representar o padrão de fluxo (Levenspiel, 1999).

$$
\mathrm{N}=\frac{1}{\sigma_{\theta}^{2}} \text { Equação } 20
$$




$$
\frac{\mathrm{D}}{\mathrm{uL}}=\frac{\sigma_{\theta}^{2}}{2} \text { Equação } 21
$$

Para se encontrar a porcentagem de recuperação do traçador foi realizada a integração da área do gráfico da concentração em função do tempo, e a multiplicação do valor encontrado pela vazão aplicada ao reator. Neste trabalho, todos os cálculos de derivadas e integrais foram realizados no programa Origin 8.0.

\subsection{Métodos Analíticos}

Para a determinação de sólidos voláteis totais (SVT) na biomassa, concentração de sólidos em suspensão voláteis (SSV) e de demanda química de oxigênio (DQO), foram utilizadas as metodologias preconizadas em American Public Health Association (APHA), American Water Works Association (AWWA ), \& Water Environment Federation (2005). A leitura da absorbância das amostras de DQO foi feita no comprimento de onda $620 \mathrm{~nm}$ utilizando espectrofotômetro $\mathrm{HACH}$ modelo 890.

O volume de biogás produzido foi medido com medidor de vazão milliGascounter (Ritter). A análise da composição do biogás gerado por cada reator $\left(\mathrm{H}_{2}, \mathrm{CO}_{2}\right.$ e $\left.\mathrm{CH}_{4}\right)$ foi realizada no cromatógrafo a gás Shimadzu GC 2010 nas seguintes condições:

Coluna capilar: Carboxen 1010, comprimento de $30 \mathrm{~m}$, diâmetro interno de $0,53 \mathrm{~mm}$ e espessura da coluna de $0,30 \mu \mathrm{m}$.

Gás de arraste: Argônio.

Temperatura inicial do injetor: $200^{\circ} \mathrm{C}$.

Temperatura inicial do detector: $230^{\circ} \mathrm{C}$.

Vazão do gás de make up (Ar): $12 \mathrm{~mL} \cdot \mathrm{min}^{-1}$.

Detector: condutividade térmica.

Volume de amostra: $200 \mu \mathrm{L}$. 
A análise de sacarose e metabólitos solúveis foi realizada por Cromatografia Líquida de Alta Eficiência (CLAE) em sistema Shimadzu, composto por: bomba LC10ADvp, válvula solenoide FCV-10ALpv, forno CTO-10Avp, controlador SCL10ADvp, detector UV com arranjo de diodos SPD-M10ADvp, detector de índice refrativo diferencial-RID-10A. As condições cromatográficas foram as seguintes:

Coluna de troca iônica: Aminex HPX-87H, comprimento de $0,3 \mathrm{~m}$, diâmetro interno de 7,8 mm;

Fase móvel: $\mathrm{H}_{2} \mathrm{SO}_{4}$;

Fluxo: $0,5 \mathrm{~mL} \cdot \mathrm{min}^{-1}$;

Detector de UV: Arranjo de diodos 205 nm;

Detector de índice refrativo diferencial: fotodiodo de 4-partições.

Volume de amostra: $100 \mu \mathrm{m}$

Temperatura de trabalho do forno: $43^{\circ} \mathrm{C}$

Temperatura máxima de trabalho: $70^{\circ} \mathrm{C}$.

\subsection{Cálculos das variáveis de produção de $\mathrm{H}_{2}$}

Os cálculos das variáveis de produção de $\mathrm{H}_{2}$ foram realizados a partir das equações seguintes, utilizando o programa Excel 2010, sendo os valores de volume apresentados nas condições padrão de temperatura e pressão (CPTP).

Vazão molar de sacarose convertida $\left(v_{S}\right)$ :

$$
v_{S}\left[m m o l \cdot h^{-1}\right]=\frac{Q \cdot\left(C_{S o}-C_{S f}\right)}{M M_{S}} \text { Equação } 22
$$

$\mathrm{Na}$ qual, $C_{S o}$ é a concentração de sacarose no meio afluente, $C_{S f}$ a concentração de sacarose no efluente e $M M_{S}$ é a massa molar da sacarose.

Vazão de biogás $\left(Q_{g}\right)$ : 


$$
Q_{g}\left[m L \cdot h^{-1}\right]=\frac{V_{m} \cdot F_{m}}{t} \text { Equação } 23
$$

$\mathrm{Na}$ qual, $\mathrm{V}_{\mathrm{m}}$ é o volume de gás marcado pelo medidor, o $\mathrm{F}_{\mathrm{m}}$ é o fator de calibração do medidor obtido por calibração com bolhômetro padrão e t é o tempo da medida.

Distribuição em porcentagem de hidrogênio $\left(\%_{\mathrm{H}_{2}}\right)$, dióxido de carbono $\left(\%_{\mathrm{CO}_{2}}\right)$ e metano $\left(\%_{\mathrm{CH}_{4}}\right)$ no biogás:

$$
\begin{gathered}
\%_{\mathrm{H}_{2}}=\frac{n_{\mathrm{H}_{2}}}{n} \quad \text { Equação } 24 \\
\%_{\mathrm{CO}_{2}}=\frac{n_{\mathrm{CO}_{2}}}{n} \quad \text { Equação } 25 \\
\%_{\mathrm{CH}_{4}}=\frac{n_{\mathrm{CH}_{4}}}{n} \quad \text { Equação } 26
\end{gathered}
$$

Nas quais, $\mathrm{n}_{\mathrm{H}_{2}}, \mathrm{n}_{\mathrm{CO}_{2}}$ e $\mathrm{n}_{\mathrm{CH}_{4}}$ correspondem à quantidade de cada um dos gases conteúdos no biogás: hidrogênio, dióxido de carbono e metano, respectivamente. Esse conteúdo foi medido por cromatografia e calculado pelas curvas de calibração do cromatógrafo. O valor de n corresponde ao número de mols totais no volume $v_{i}$ de amostra de gás injetado, calculado a partir dos dados cromatográficos.

Vazão molar de hidrogênio $(V M H)$ :

$$
V M H\left[\mathrm{mmol} \cdot h^{-1}\right]=Q_{g} \cdot \frac{n_{H_{2}}}{V_{i}} \text { Equação } 27
$$

Rendimento de hidrogênio $\left(Y_{\mathrm{H}_{2}}\right)$ :

$$
Y_{H_{2}}\left[m o l H_{2} \cdot m o l-s a c^{-1}\right]=\frac{V M H}{v_{S}} \text { Equação } 28
$$

Produção volumétrica de hidrogênio $(P V H)$ :

$$
P V H\left[m L_{H_{2}} \cdot h^{-1} \cdot L^{-1}\right]=\frac{Q_{g} \cdot \%_{H_{2}}}{V} \text { Equação } 29
$$




\subsection{Análises microbiológicas}

As análises microbiológicas da biomassa desenvolvida em cada operação e do lodo utilizado para a inoculação do reator UASB foram realizadas para verificar as mudanças na comunidade microbiana devido às condições operacionais. As amostras foram coletadas nos seguintes dias operacionais do reator UASB: 110 (U12A), 211 (U12B), 282 (U6) e 366 (U2). Em todas as coletas, a amostragem foi composta, contendo parcelas dos três pontos de coleta ao longo do leito de lodo. Para o reator tubular sem material suporte, a amostra de cada operação (TSS2 para TDH de $2 \mathrm{~h}$, e TSS0,5 para TDH de 0,5 h) foi composta das parcelas coletas ao longo de todo o reator, no último dia de operação. No caso do reator tubular com leito empacotado, as amostras, também retidas no último dia de operação, foram compostas, mas separadas entre os pontos ao longo do leito empacotado (TCS2LE, para TDH de $2 \mathrm{~h}$, e TCS0,5LE, para TDH de $0,5 \mathrm{~h}$ ) e os pontos do compartimento de acúmulo (TCS2CA, para TDH de 2 h, e TCS0,5CA, para TDH de 0,5 h).

O DNA foi extraído das amostras de acordo com o protocolo modificado de Griffiths et al (Griffiths, Whiteley, O'Donnell, \& Bailey, 2000), através de agitação com pérolas de vidro, clorofórmio, fenol e solução tampão. A purificação dos fragmentos de DNA foi realizada com GFX 96 Purification Kit (GE Healthcare Life Sciences). Em seguida, a amplificação dos frangmentos 16S rRNA para o domínio bactéria (968fGC - 1392R) foi obtida através de reação em cadeia de polimerase (PCR) (Nübel et al., 1996). Eletroforese em gel de gradiente desnaturante (DGGE) foi realizada utilizando concentração de gradientes de $45 \%$ e $65 \%, 75 \mathrm{~V}$ à $60^{\circ} \mathrm{C}$ por $16 \mathrm{~h}$ (Muyzer, de Waal, \& Uitterlinden, 1993). O gel de DGGE foi deixado em solução de brometo de etídio por 20 min e em seguida colocado no equipamento Eagle Eye TM III (Stratagene), sob luz UV de 254nm e conectado ao programa Eagle Slight para a visualização das bandas. $O$ agrupamento das bandas foi realizado no programa Bionumerics 2.5 utilizando índice de Jaccard. 


\subsection{Métodos Estatísticos}

Todos os testes estatísticos foram realizados utilizando o programa Statistica 10. Realizaram-se os testes de Shapiro-Wilk, Lilliefors e Kolmogorov-Sminorv com $p$ valor igual a 0,05 , para testar a normalidade das distribuições dos dados obtidos para: $\mathrm{PVH}, \mathrm{VMH}, \mathrm{pH}$, porcentagem de $\mathrm{H}_{2}$ no biogás, porcentagem de conversão de sacarose, rendimento de $\mathrm{H}_{2}$ e SSV. Sendo consideradas normais quando havia concordância entre os três testes. Como para todas as variáveis havia uma ou mais distribuições que não poderiam ser consideradas normais, ou o tamanho de um dos conjuntos amostrais era pequeno (inferior a 15), utilizou-se o teste não paramétrico para comparação de dois grupos amostrais independentes Wald-Wolfowitz. O teste é equivalentes ao teste $\mathrm{t}$ de Student $\mathrm{e}$ utilizado quando as distribuições dos conjuntos de dados não se ajusta à normal. O teste Wald-Wolfowitz avalia se as distribuições de dados são diferentes na média e também considera a forma das distribuições, assegurando que as amostras populacionais são mutualmente independentes.

\subsection{Protocolo experimental da etapa 2 - Verificação da condição nutricional ótima}

Foram realizados ensaios em batelada utilizando frascos Duran de $500 \mathrm{~mL}$, considerando volume útil de $250 \mathrm{~mL}$, e mantidos em câmara sem agitação à $55^{\circ} \mathrm{C}$. Os frascos foram inoculados com lodo produzido ao longo das quatro operações do reator tubular (com e sem material suporte e submetido a TDH de $2 \mathrm{~h}$ e $0,5 \mathrm{~h}$ ), o qual, após o término da última operação, fora homogeneizado e armazenado a $4^{\circ} \mathrm{C}$. A concentração de sólidos suspensos voláteis (SSV) nos frascos reacionais foi de $0,11 \pm 0,01 \mathrm{gSSV} \cdot \mathrm{L}^{-1}$, a mesma encontrada no reator na condição TCS2.

O substrato sintético admitido como base, para ser testado posteriormente como controle, foi aquele utilizado nas operações contínuas, alterando a concentração de sacarose para $0,5 \mathrm{~g} \cdot \mathrm{L}^{-1}$ e assim, proporcionalmente, os demais componentes. Nos planejamentos experimentais foi alterada a composição de nutrientes, porém as concentrações de sacarose, bicarbonato e cálcio adotadas 
como base, permaneceram as mesmas, assim como as relações nitrogênio/fósforo e potássio/sódio.

$\mathrm{O}$ pH foi do meio foi ajustado para 7,0 e, após selados, os frascos passaram por purga com $\mathrm{N}_{2}$ para garantir o ambiente anaeróbio e, em seguida, foi retirada a amostra gasosa inicial. Ao final da fase lag, determinada em ensaio prévio, a produção molar de $\mathrm{H}_{2}$ foi acompanhada através de amostras gasosas retiradas a cada 3 horas durante a fase exponencial, sendo esse intervalo aumentado de forma gradual até a estabilização. Ao final do experimento, foram realizadas análises para determinar a degradação da sacarose e a concentração de SSV.

\subsubsection{Planejamento fatorial do experimento em batelada}

O delineamento dos experimentos em batelada e a análise dos dados foram realizadas no programa Statistica 11 , sendo que os seguintes planejamentos foram adotados: Plackett-Bruman, para identificar os nutrientes com influência significativa nas respostas consideradas; método da diagonal de maior inclinação (Steepest Ascent), visando, a partir das curvas de concentrações de nutrientes versus resposta, fornecidas pelo planejamento anterior, variar as concentrações em direção à região ótima; Composto Central, com o objetivo de encontrar os valores de concentração que otimizam as respostas consideradas, dentro da região de máximos identificada no planejamento precedente.

A princípio, as respostas consideradas foram a velocidade molar de produção de $\mathrm{H}_{2}(\mathrm{VMPH})$ e o rendimento de $\mathrm{H}_{2}\left(\mathrm{YH}_{2}\right)$, por serem importantes em considerações a respeito da viabilidade econômica e eficiência do processo, respectivamente. Essas variáveis foram obtidas a partir dos parâmetros de ajuste da curva de produção de hidrogênio ao longo do experimento ao modelo de Gompertz modificado (Zwietering, Jongenburger, Rombouts, \& van't Riet, 1990), utilizando o algoritmo de Levenberg-Marquardt aplicado ao método de mínimos quadrados.

O planejamento Plackett-Burman foi projetado de forma randômica, para ensaios em duplicata com 7 fatores, 2 níveis (inferior e superior) e ponto central, resultando em 18 ensaios (frascos). As concentrações de nutrientes adotadas no planejamento são apresentadas na Tabela 2. 
Tabela 2 - Concentrações e nutrientes testados no planejamento Plackett-Burman.

\begin{tabular}{|c|c|c|c|c|}
\hline \multirow[b]{2}{*}{ Nutrientes } & \multirow[b]{2}{*}{ Fatores } & \multicolumn{3}{|c|}{ Valores testados para cada fator $\left(\mathrm{mg} \cdot \mathrm{L}^{-1}\right)$} \\
\hline & & $\begin{array}{c}\text { Nível inferior } \\
(-1)\end{array}$ & $\begin{array}{l}\text { Ponto central } \\
\text { (0) }\end{array}$ & $\begin{array}{c}\text { Nível superior } \\
(+1)\end{array}$ \\
\hline \multicolumn{5}{|l|}{$\mathrm{CH}_{4} \mathrm{~N}_{2} \mathrm{O}$} \\
\hline $\mathrm{KH}_{2} \mathrm{PO}_{4}$ & \multirow{3}{*}{$C: N: P$} & \multirow{3}{*}{$60: 3: 1$} & \multirow{3}{*}{$330: 3: 1$} & \multirow{3}{*}{$600: 3: 1$} \\
\hline $\mathrm{K}_{2} \mathrm{HPO}_{4}$ & & & & \\
\hline $\mathrm{Na}_{2} \mathrm{HPO}_{4}$ & & & & \\
\hline $\mathrm{CoCl}_{2} \cdot 6 \mathrm{H}_{2} \mathrm{O}$ & $\mathrm{Co}^{+2}$ & 0,005 & 0,0275 & 0,05 \\
\hline $\mathrm{FeSO}_{4} .7 \mathrm{H}_{2} \mathrm{O}$ & $\mathrm{Fe}^{2+}$ & 1,00 & 5,50 & 10,00 \\
\hline $\mathrm{MgCl}_{2} .6 \mathrm{H}_{2} \mathrm{O}$ & $\mathrm{Mg}^{2+}$ & 1,00 & 5,50 & 10,00 \\
\hline $\mathrm{NiSO}_{4} .6 \mathrm{H}_{2} \mathrm{O}$ & $\mathrm{Ni}^{2+}$ & 0,010 & 0,055 & 0,100 \\
\hline $\mathrm{SeO}_{2}$ & $\mathrm{Se}^{2+}$ & 0,005 & 0,0275 & 0,05 \\
\hline $\mathrm{ZnCl}_{2}$ & $\mathrm{Zn}^{2+}$ & 0,010 & 0,055 & 0,100 \\
\hline
\end{tabular}

A partir das respostas dos ensaios anteriores foram definidos os fatores com influência significativa (ANOVA com nível de significância de 5\%) e ajustadas curvas lineares dos valores dos fatores significativos em função das respostas consideradas. Os coeficientes das curvas ajustadas foram utilizados para determinar os incrementos $(\Delta)$ nos valores dos fatores significativos. Os valores de $\Delta$ partem do mesmo ponto central do planejamento anterior e implicam em acréscimo no valor do fator se seu coeficiente na curva é positivo e decréscimo se for negativo. Para o fator com maior valor de coeficiente, em módulo, o valor de $\Delta$ corresponde ao mesmo incremento adotado no planejamento anterior. Para os demais, o $\Delta$ é dado pela relação entre seu coeficiente e o maior coeficiente na curva. Assim, no método diagonal de maior inclinação, foram testados $4 \Delta$ para os fatores $\mathrm{C}: \mathrm{N}: \mathrm{P}, \mathrm{Fe}^{+2}$ e Ni${ }^{+2}$, utilizando triplicata e os valores de concentração da Tabela 3.

Tabela 3 - Concentrações utilizadas no planejamento pelo método da diagonal de maior inclinação.

\begin{tabular}{cccc}
\hline Ensaios & \multicolumn{3}{c}{ Valores testados para cada fator $\mathbf{( \mathbf { m g } \cdot \mathbf { L } ^ { - 1 } )} \mathbf{\mathbf { N i } ^ { + 2 }}$} \\
\hline Central & $330: 3: \mathbf{P}$ & 5,5 & 0,055 \\
Central $+1 \Delta$ & $100: 3: 1$ & 10,0 & 0,078 \\
Central $+2 \Delta$ & $50: 3: 1$ & 14,5 & 0,101 \\
Central $+3 \Delta$ & $25: 3: 1$ & 19,0 & 0,124 \\
Central $+4 \Delta$ & $10: 3: 1$ & 23,5 & 0,147 \\
\hline
\end{tabular}


Uma vez verificado que a VPHe o $\mathrm{YH}_{2}$ apresentavam picos dentro das faixas de valores testadas, seguiu-se para o experimento utilizando Composto Central. O planejamento foi elaborado de forma randômica para ensaio em duplicata, com 3 fatores, valor de rotatividade de 1,6818 e cujos pontos centrais foram as concentrações com as quais foram observados os picos de $\mathrm{VPH}$ e $\mathrm{YH}_{2}$ (Tabela 4).

Tabela 4 - Valores para a região ótima testados no planejamento Composto Central.

\begin{tabular}{cccccc}
\hline \multirow{2}{*}{ Fatores } & $\mathbf{5}$ Valores testados para cada fator $\mathbf{( m g} \cdot \mathbf{L}^{-1}$ ) & \\
& $\mathbf{- 1 , 6 8 1 8}$ & $\mathbf{- 1}$ & $\mathbf{0}$ & $\mathbf{1}$ & $\mathbf{1 , 6 8 1 8}$ \\
\hline $\mathrm{C}: \mathrm{N}: \mathrm{P}$ & $5: 3: 1$ & $13: 3: 1$ & $25: 3: 1$ & $37: 3: 1$ & $45: 3: 1$ \\
$\mathrm{Fe}^{+2}$ & 0,50 & 2,53 & 5,50 & 8,47 & 10,50 \\
$\mathrm{Ni}^{+2}$ & 0,005 & 0,025 & 0,055 & 0,085 & 0,105 \\
\hline
\end{tabular}

Como os experimentos utilizando o Composto Central produziram resultados inesperados, possivelmente por serem valores muito baixos e interferirem no crescimento da biomassa, variável não avaliada nos ensaios anteriores, novo experimento utilizando o Composto Central foi realizado apenas para a otimização da variável $\mathrm{YH}_{2}$ a partir de $\mathrm{Ni}^{+2}$ e $\mathrm{Fe}^{+2}$ (Tabela 5). Como o experimento foi divido em duas etapas, devido à limitação no número máximo de leituras possível no intervalo do período exponencial, o novo experimento foi planejado em blocos, tornando possível a avaliação da diferença causada por fatores externos. Ao se realizar a blocagem do planejamento, os coeficientes de rotatividade e ortogonalidade se igualam e apresentam valor de $\sqrt{ } 2$.

Tabela 5 - Valores para a região ótima testados no segundo experimento planejamento Composto Central.

\begin{tabular}{cccccc}
\hline Fatores & \multicolumn{5}{c}{ Valores testados para cada fator $\left(\mathbf{m g} \cdot \mathbf{L}^{-\mathbf{1}}\right)$} \\
& $-\sqrt{\mathbf{2}}$ & $\mathbf{- 1}$ & $\mathbf{0}$ & $\mathbf{1}$ & $\sqrt{\mathbf{2}}$ \\
\hline $\mathrm{Fe}^{+2}$ & 1,257 & 2,5 & 5,5 & 8,5 & 9,743 \\
$\mathrm{Ni}^{+2}$ & 0,012 & 0,025 & 0,055 & 0,085 & 0,097 \\
\hline
\end{tabular}




\section{Resultados e Discussão}

\subsection{Etapa 1 - Operação de reatores}

\subsubsection{Ensaios hidrodinâmicos}

A partir dos resultados dos ensaios hidrodinâmicos, as curvas $E$ foram plotadas em função do tempo de ensaio e são apresentadas na Figura 5, onde os valores de ambas as variáveis foram divididas pelo TDH médio $\left(\overline{\theta_{h}}\right)$, para que seja possível a comparação entre diferentes $\mathrm{TDH}$, sendo possível visualizar a influência do TDH no tipo de escoamento do escoamento nos reatores em estudo, bem como anomalias e alterações devido à agregação de biomassa.
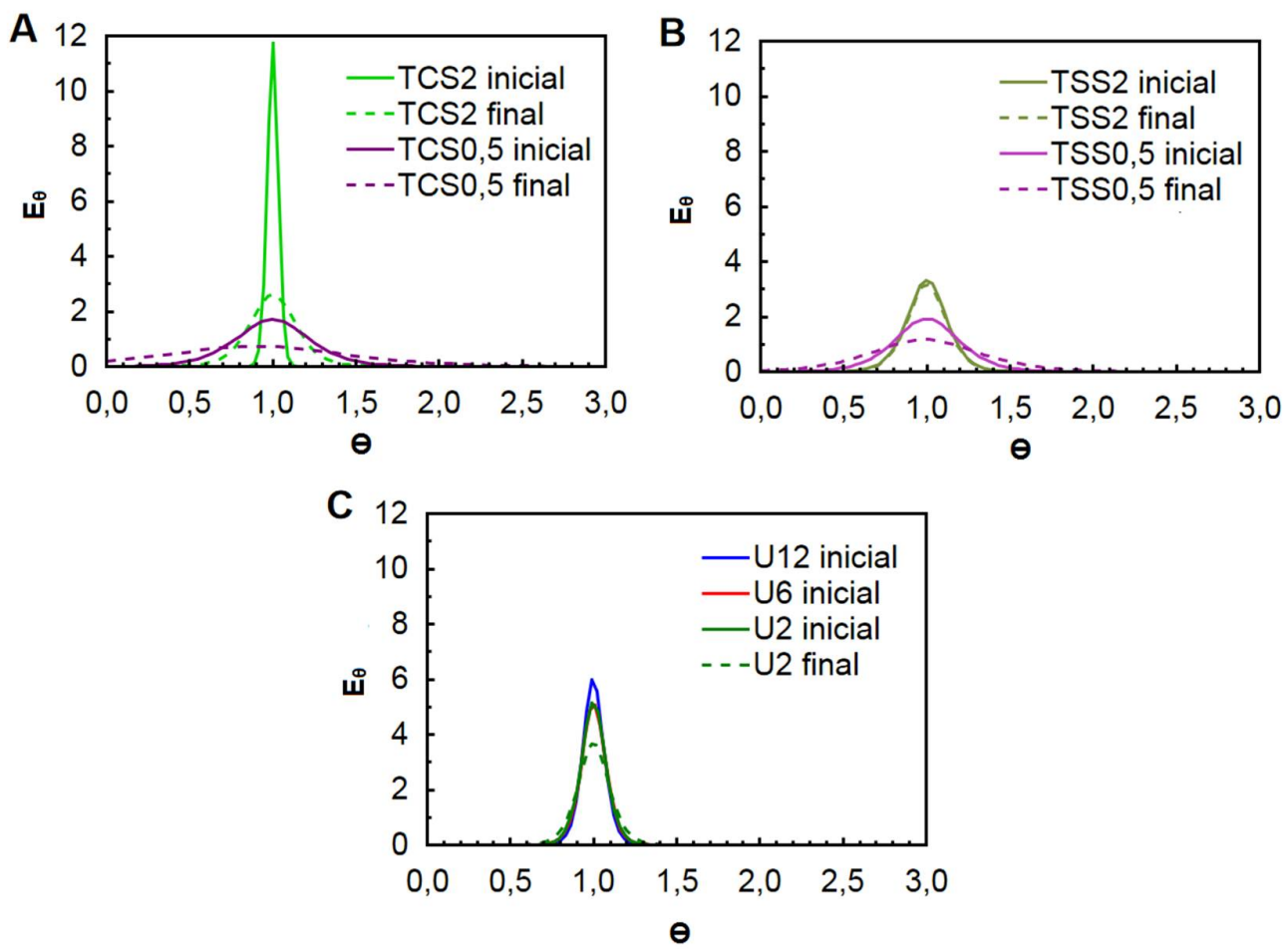

Figura 5 - Curvas $\mathrm{E}_{\theta}$ função de $\theta$ obtidas para cada operação. 
Nas análises iniciais dos reatores tubulares, $\mathrm{O}$ TDH de $2 \mathrm{~h}$ propiciou $\mathrm{o}$ estabelecimento de escoamento pistonado tanto na presença quanto na ausência de material suporte, como é demonstrado na Tabela 6 através do número de tanquesem-série (N), uma vez que segundo Levenspiel (1999), valores de $\mathrm{N}$ a partir de 30 já permitem a modelagem do reator como pistonado e dispersões inferires a 0,01 são consideradas de pequena intensidade.

Tabela 6 - Dados experimentais dos ensaios hidrodinâmicos.

\begin{tabular}{|c|c|c|c|c|c|c|c|c|}
\hline \multirow{2}{*}{ Reator } & \multirow{2}{*}{$\begin{array}{c}\mathrm{TDH}^{(\mathrm{a})} \\
\text { (h) }\end{array}$} & \multirow[t]{2}{*}{$\mathrm{Etapa}^{(\mathrm{b})}$} & \multirow{2}{*}{$\begin{array}{l}\overline{\theta_{\mathrm{h}}}(\mathrm{c}) \\
(\mathrm{h})\end{array}$} & \multirow[t]{2}{*}{$\mathbf{N}^{(\mathrm{d})}$} & \multirow[t]{2}{*}{ D/uL ${ }^{(e)}$} & \multirow{2}{*}{$\begin{array}{c}\text { Recuperação } \\
\text { do traçador }{ }^{(f)} \\
(\%)\end{array}$} & \multicolumn{2}{|c|}{$\begin{array}{l}\text { R modelo de } \\
\text { dispersão }\end{array}$} \\
\hline & & & & & & & Baixa & Alta \\
\hline \multirow{4}{*}{ UASB } & 12 & \multirow{3}{*}{ Inicial } & 11,4 & 199 & 0,0025 & 67 & 1,00 & 1,00 \\
\hline & 6 & & 5,9 & 144 & 0,0035 & 66 & 1,00 & 1,00 \\
\hline & 2 & & 1,8 & 142 & 0,0035 & 69 & 0,99 & 1,00 \\
\hline & 2 & Final & 2,6 & 82 & 0,0061 & 55 & 1,00 & 0,99 \\
\hline \multirow{4}{*}{$\operatorname{TCS}^{(\mathrm{h})}$} & 2 & \multirow{2}{*}{ Inicial } & 2,1 & 839 & 0,0012 & 65 & 1,00 & 0,98 \\
\hline & 0,5 & & 0,5 & 15 & 0,0340 & 68 & 0,99 & 0,99 \\
\hline & 2 & \multirow{2}{*}{ Final } & 1,9 & 38 & 0,0262 & 69 & 0,99 & 1,00 \\
\hline & 0,5 & & 0,3 & 3 & 0,1785 & 81 & 0,99 & 0,95 \\
\hline \multirow{4}{*}{ TSS $^{(i)}$} & 2 & \multirow{2}{*}{ Inicial } & 1,7 & 53 & 0,0094 & 68 & 1,00 & 1,00 \\
\hline & 0,5 & & 0,5 & 19 & 0,0271 & 62 & 0,99 & 0,99 \\
\hline & 2 & & 1,8 & 54 & 0,0093 & 70 & 1,00 & 1,00 \\
\hline & 0,5 & In & 0,5 & 7 & 0,0738 & 63 & 1,00 & 0,98 \\
\hline
\end{tabular}

(a) TDH teórico aplicado aos reatores;

(b) Os testes foram realizados antes do reator entrar em operação (etapa inicial) e no último dia de operação (etapa final).

(c) TDH médio;

(d) Número de reatores em série;

(e) Coeficiente de dispersão longitudinal;

(f) Porcentagem da massa de traçador injetada que foi recuperada;

(g) Correlação entre as curvas DTR experimentais e as curvas de modelos teóricos para alta e baixa dispersão.

(h) Reator tubular de leito empacotado;

(i) Reator tubular sem material suporte.

Apesar de o leito empacotado ter proporcionado uma diminuição de quase 8 vezes no valor da dispersão quando aplicado TDH de $2 \mathrm{~h}$, o material suporte mostrou pouca interferência quando o TDH aplicado foi de $0,5 \mathrm{~h}$, e o escoamento apresentou tendência à mistura completa, provavelmente devido aos valores de $v_{\text {asc }}$ iguais a 82,8 e $150,4 \mathrm{~cm} \cdot \mathrm{h}^{-1}$, para TCS0,5 e TSS0,5, respectivamente. A partir os ensaios no final das operações, é possível observar que o crescimento de biomassa no TCS, para ambos os TDH, e no TSS0,5 proporcionou aumento na dispersão 
longitudinal, enquanto que a agregação de biomassa nas paredes e no fundo do TSS com TDH de 2 h não afetou a dispersão. Portanto, mesmo com aumento de quase 5 vezes na velocidade ascensional, a biomassa pode aderir ao reator TSS0,5 e a elevada carga orgânica causou o crescimento de biomassa em maior proporção em relação a TSS2, levando a alteração no escoamento no interior do reator.

No reator UASB houve aumento na dispersão no final da operação, com diferença significativa ao nível de 0,05 na curva DTR comparada às curvas iniciais. Ainda assim, o modelo de escoamento pistonado é adequado para representar o reator UASB em todas as condições. Esse resultado difere de outros estudos (López \& Borzacconi, 2010; T. Ren, Mu, Ni, \& Yu, 2009) e do conceito usual de que reatores UASB estão mais próximos do fluxo de mistura completa (Sinha \& Pandey, 2011), adotado quando ensaios hidrodinâmicos não são realizados. Essa divergência pode ser resultado da presença de biomassa durante a realização dos ensaios.

A recuperação média do traçador nos ensaios realizados foi de $67 \pm 6 \%$. Os ensaios no final das operações do UASB2 e TCS0,5 resultaram em recuperações de traçador com maior diferença em relação à media, $18 \%$ inferior e $21 \%$ superior, respectivamente. Os valores obtidos para o tempo médio de residência $\left(\overline{\theta_{\mathrm{h}}}\right)$ para UASB2 e TCS0,5 também foram os únicos a apresentarem discrepância em relação ao valor esperado, respectivamente, $30 \%$ superior e $40 \%$ inferior.

A recuperação do traçador é um parâmetro que indica a porcentagem da massa de traçador injetada que deixou o reator, e pode ser utilizado para indicar erros no ensaio. Problemas com o traçador (como reatividade, absorção, dispersão e difusão no biofilme) aumentam seu o tempo de residência no sistema, diminuem sua recuperação ao final do ensaio e podem ser detectados comparando as curvas E (ou DTR) experimentais às curvas teóricas dos modelos de baixa e alta dispersão, conforme utilizado por Nardi, Zaiat, \& Foresti (1999) para avaliação da eficiência de traçadores. Os coeficientes de correlação encontrados apresentam valores próximos a 1, demonstrando que, apesar da baixa recuperação, o traçador se mostrou satisfatório. Assim, pode-se considerar que as curvas E são adequadas para representar os fenômenos ocorridos nos reatores. 
Assim, conforme Levenspiel (1999), o adiantamento no $\overline{\theta_{\mathrm{h}}}$ do TCS0,5 se deve pela formação de zonas mortas, possivelmente criadas pela agregação de biomassa nos interstícios do material suporte em proporção bastante superior a TCS2, no qual não foi verificado o mesmo fenômeno.

Para o caso do pico tardio do U2 no final da operação, entre as possíveis causas apontadas por Levenspiel (1999) são: erro na medição da vazão, problemas de adsorção do traçador ou descumprimento da condição de sistema fechado. Assim, como o traçador se mostrou adequado e a condição de sistema fechado não ter sido alterada, a causa mais provável seria erro na medição de vazão. Tal erro pode ser resultado de mudanças na biomassa da condição inicial (Figura 6A) para a encontrada no final da operação (Figura 6B). Conforme a Figura 6B, a maior produção de exopolímeros pela biomassa quando exposta à diminuição do TDH pode ter causado aumento na densidade do leito de lodo, o que pode ser confirmado pelo aumento da perda de carga no reator, com necessidade de ajuste da velocidade da bomba durante a operação para a manutenção da vazão volumétrica desejada.
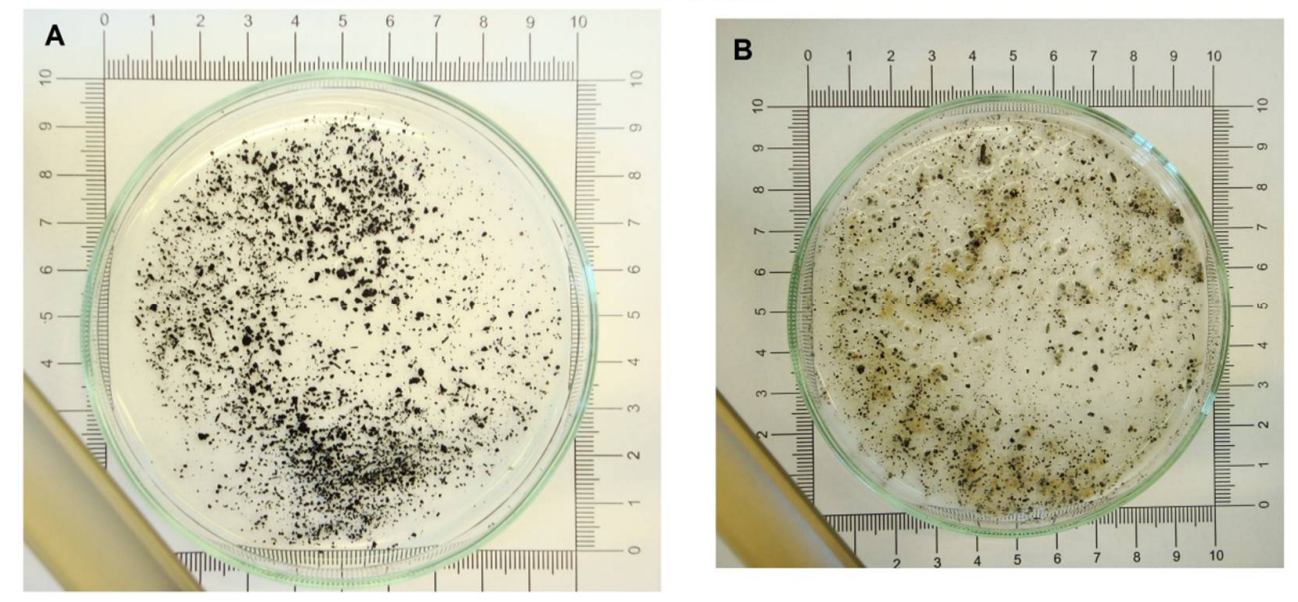

Figura 6 - Grânulos utilizados para a inoculação do reator (A) e grânulos ao final da operação (B).

\subsubsection{Influência do TDH na operação do reator UASB}

Após o ensaio hidrodinâmico e o período de recirculação, iniciou-se a operação do reator UASB em fluxo contínuo. Apesar do tratamento térmico da 
biomassa, foi verificada a presença de $\mathrm{CH}_{4}$ no biogás com valor máximo de $50,1 \%$ no dia 14 (Figura 7A), diminuindo gradualmente até chegar a zero no dia 56. Até o dia 47, a concentração de SSV foi de 2 a 3 vezes superior a média do período operacional restante com TDH de $12 \mathrm{~h}$ (Figura 7B). A $\mathrm{v}_{\text {asc }}$ aplicada ao reator e, consequentemente, a força de cisalhamento provavelmente desagregaram a parte da biomassa, levando ao fenômeno de lavagem (wash out) dos grânulos por superar sua velocidade de sedimentação (Mahmoud, Zeeman, Gijzen, \& Lettinga, 2003). O estabelecimento de ambiente acidificante é confirmado pelo decréscimo no $\mathrm{pH}$ (Figura 7B).
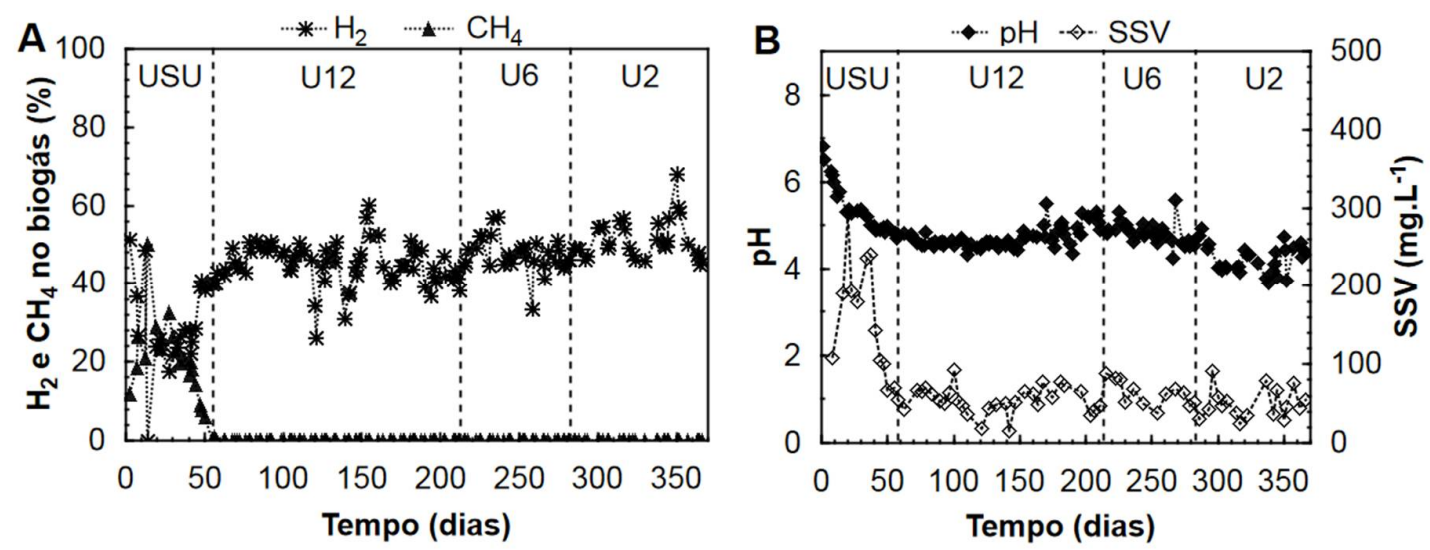

Figura 7 - Porcentagem de $\mathrm{H}_{2}$ e $\mathrm{CH}_{4}$ no biogás $(A)$, pH e e a concentração de sólidos suspensos voláteis (SSV) no efluente (B) durante as operações em reator UASB: USU, partida do reator; U12, UASB com TDH de 12h; U6, UASB com TDH de 2.

Após 10 dias de operação contínua de reator de mistura, Luo, Xie, Zou, Wang, \& Zhou (2010) não observaram diferenças na produção de $\mathrm{H}_{2}$ termofílica a partir de vinhaça de mandioca por lodos que passaram por diferentes prétratamentos e por inóculo não tratado. Em estudo desenvolvido por Penteado et al. (Penteado et al., 2013), testando diferentes inóculos em reator de leito empacotado e usando substrato a base de sacarose, o tratamento térmico não melhorou a produção de $\mathrm{H}_{2}$ e nem inibiu a metanogênese em todos os inóculos testados. A partir do observado no presente estudo e na literatura, ainda que o tratamento térmico aumente a proporção de bactérias formadoras de esporos e conduza o esporo de Clostridium à germinação (Hawkes et al., 2007), condições termofílicas e outras características operacionais do sistema (baixo $\mathrm{pH}$ e TDH e alta $\mathrm{v}_{\text {asc}}$ ) parecem 
Produção de hidrogênio em reatores anaeróbios termofílicos

ser as maiores responsáveis pelo estabelecimento da comunidade microbiana desejada.

O sistema suportou aumento na COV de 4 para $24 \mathrm{~g}$ DQO. $\mathrm{L}^{-1} \cdot \mathrm{d}^{-1}$ com efeitos positivos sobre a produção de $\mathrm{H}_{2}$ pois, apesar da queda no $\mathrm{pH}$, a porcentagem de $\mathrm{H}_{2}$ e a eficiência do sistema em converter sacarose foram estatisticamente superiores em U2 com valores médios iguais a $51,5 \pm 5,1$ e 79,3 $\pm 18,7 \%$, respectivamente (Tabela 7). Em consequência disso, apesar das variações nos valores médios de $\mathrm{YH}_{2}$ não terem sido estatisticamente significativas, foi verificado aumento significativo em VMH e PVH, seguindo uma relação de ordem -1,4 com o TDH.

Tabela 7 - Valores médios obtidos para as variáveis de produção de $\mathrm{H}_{2}$ ao longo da operação do reator UASB.

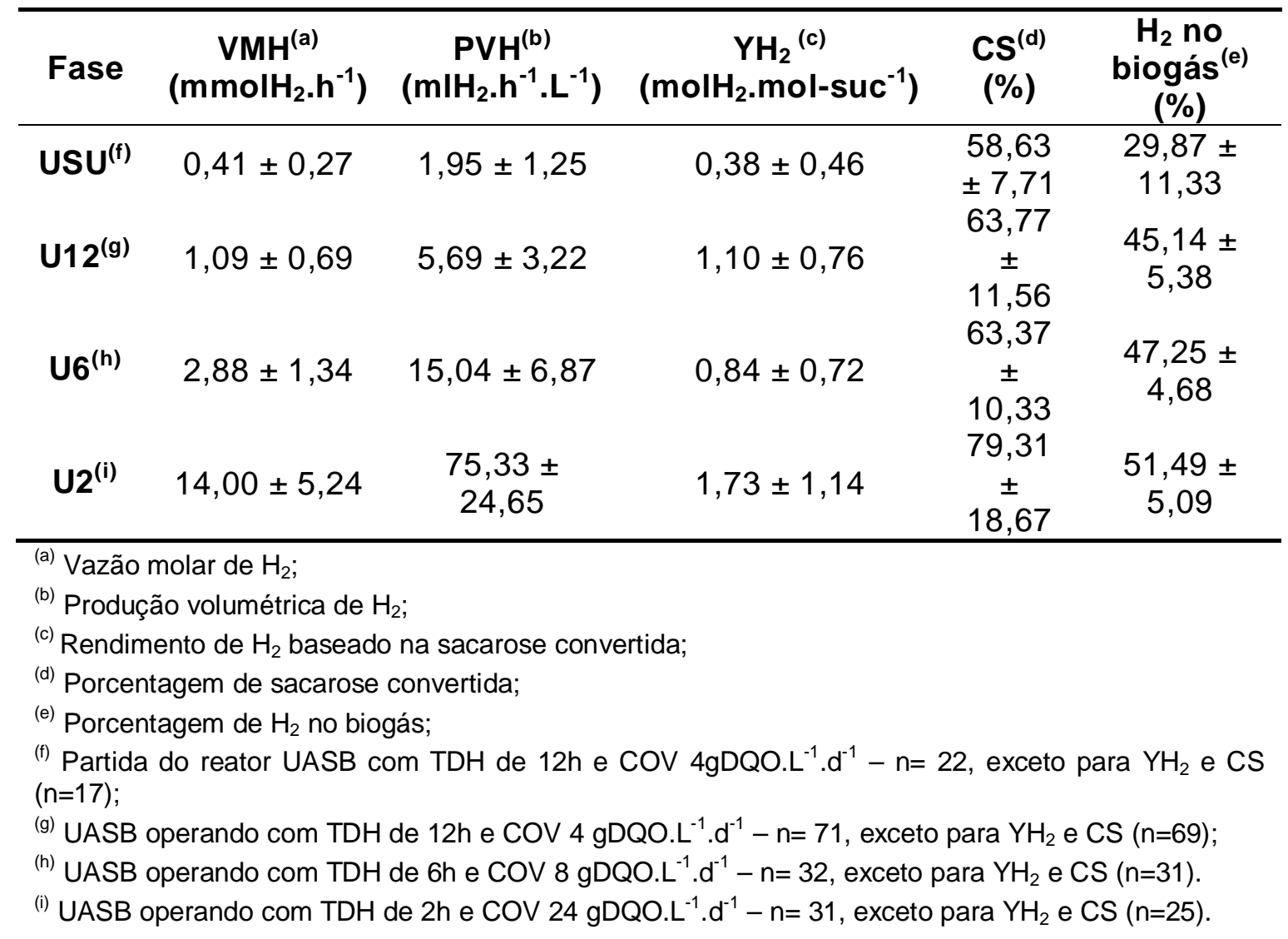

Reatores com fluxo pistonado possuem a vantagem de separação longitudinal dos metabólitos intermediários. Essa característica os torna mais resistentes a choques de carga orgânica e a inibição por produtos da fermentação. Contudo, a 
falta de mistura pode resultar em maior resistência à transferência de massa. Zhang et al. (Zhang, Zhang, Chen, \& Zeng, 2012a) demonstraram supersaturação em reator de mistura operando a $55^{\circ} \mathrm{C}$ e alimentado com solução a base de glicose. Os valores de $\mathrm{H}_{2}$ encontrados na fase líquida foram entre 1,7 e 3 vezes maiores que os valores teóricos. Aumentando a COV e diminuindo a mistura no reator, os autores observaram que a supersaturação de $\mathrm{H}_{2}$ aumentou e a conversão de sacarose caiu, sendo maior a influência da mistura do que da COV.

Portanto, o aumento na $v_{\text {asc }}$ aplicada ao reator de 4,8 para $9,5 \mathrm{~cm} \cdot \mathrm{h}^{-1} \mathrm{e}$, posteriormente, para $28.5 \mathrm{~cm} \cdot \mathrm{h}^{-1}$, possivelmente facilitou a transferência de massa líquido-gás, aumentando assim a porcentagem de $\mathrm{H}_{2}$ no biogás e a CS em U2 com significância estatística. Lima \& Zaiat (Lima \& Zaiat, 2012) aplicaram diferentes graus de mistura em reator de leito fixo, o que modifica a $v_{\text {asc }}$ do reator, e conseguiram otimizar a produção de $\mathrm{H}_{2}$ através desse valor. Lee et al. 2006 (K. Lee, Lo, Lin, \& Chang, 2006) avaliaram a influência do TDH e razão L/D, consequentemente $v_{\text {asc }}$, na produção de $\mathrm{H}_{2}$ usando reator CIGSB (carrier-induced granular sludge bed) e os resultados obtidos mostraram que decréscimo no TDH e aumento na $v_{\text {asc }}$ melhoram a produção de $\mathrm{H}_{2}$ até um ponto ótimo.

Apesar do reator UASB ter sido capaz de produzir $\mathrm{H}_{2}$ em todas as condições aplicadas, a eficiência do processo apresentou flutuações (Figura 8). Após período de adaptação, o aumento da COV resultava no melhora de $\mathrm{PVM}, \mathrm{VMH}$ e $\mathrm{YH}_{2}$ até um ponto de máximo, decrescendo em seguida no final de U12 e U6. Uma hipótese é de que a queda na relação substrato/microrganismos (COV específica) após em certo tempo operacional, conduza a rotas metabólicas menos eficientes. Ademais, a COV específica também varia ao longo do reator UASB devido ao seu escoamento pistonado. 

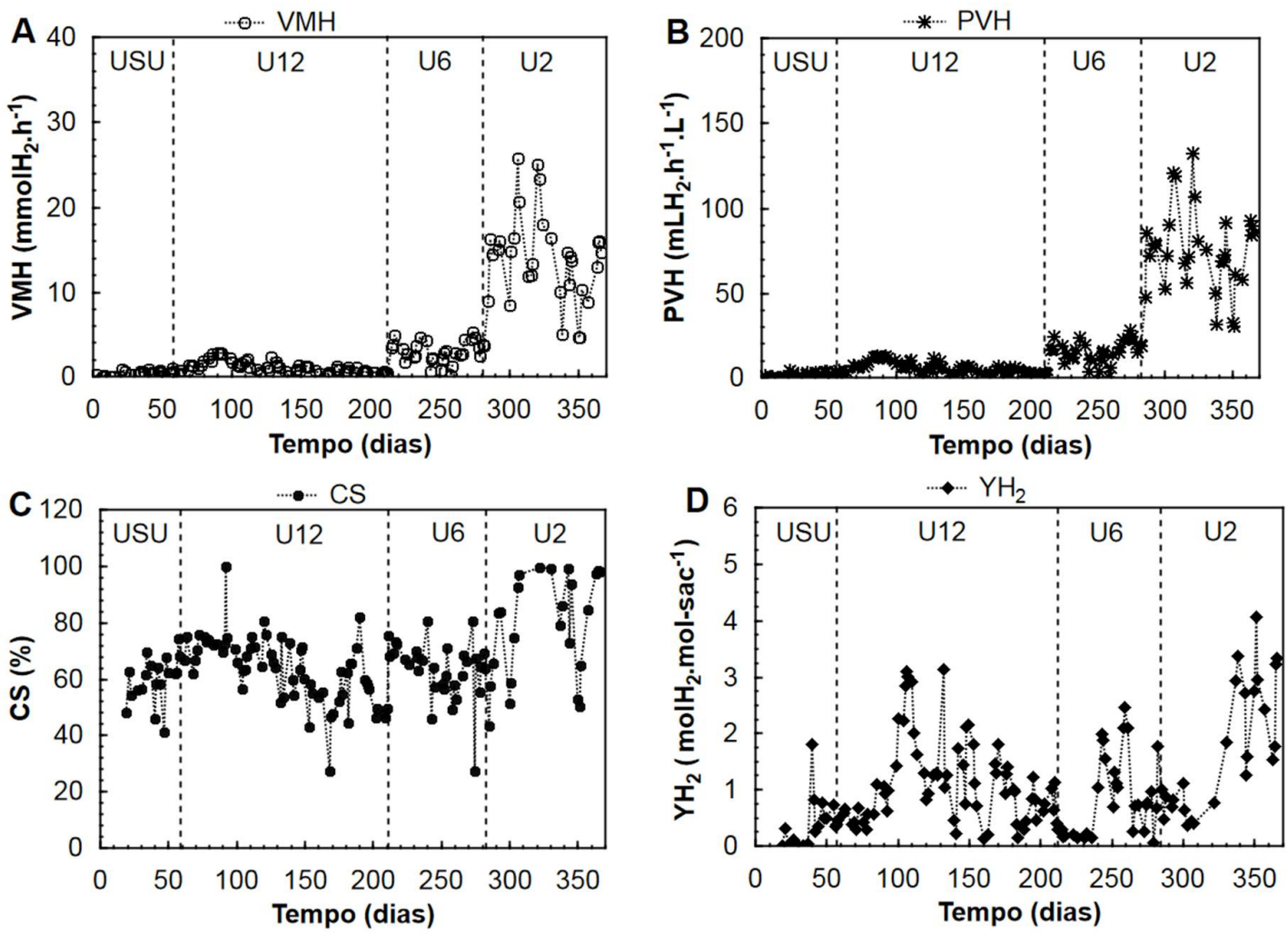

Figura 8 - Visão geral do desempenho do reator UASB na produção de $\mathrm{H}_{2}$ em todas as etapas: USU, partida do reator; U12, UASB com TDH de 12h; U6, UASB com TDH de 2.. VMH: vazão molar de $\mathrm{H}_{2} ; \mathrm{PVH}$ : produção volumétrica de $\mathrm{H}_{2}$; $\mathrm{CS}$ : conversão de sacarose; $\mathrm{YH}_{2}$ : rendimento de $\mathrm{H}_{2}$.

Na Figura 9 é apresentada a dinâmica de PMS ao longo da operação. A produção de $\mathrm{H}_{2}$ depende dos produtos finais formados e os microrganismos podem mudar sua rota metabólica preferencial dependendo das condições $(\mathrm{pH}, \mathrm{COV}$ específica, potencial redox, pressão parcial de $\mathrm{H}_{2}$, etc.). Durante a partida do reator, a acidogênese foi a principal rota metabólica, com ácido acético, butírico e propiônico $82 \%$ dos ácidos graxos voláteis (AGV). A partir de U12 o padrão metabólico passou a ser a solventogênese. 

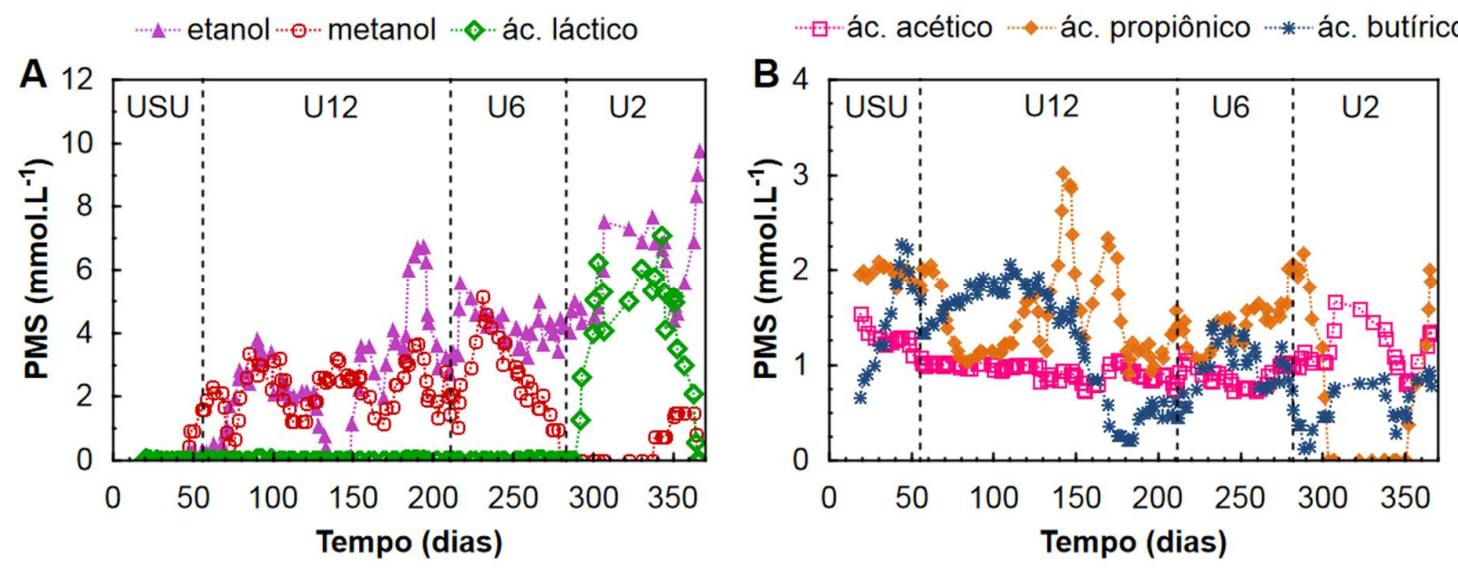

Figura 9 - Concentração dos produtos metabólicos solúveis (PMS) produzidos através da acidogênese e solventogênese em reator UASB: USU, partida do reator; U12, UASB com TDH de 12h; U6, UASB com TDH de 2.

Os maiores valores de $\mathrm{YH}_{2}$ (em torno de $3 \mathrm{molH}_{2} \cdot \mathrm{mol}_{-\mathrm{sac}^{-1}}$ ) durante U12 ocorreram concomitantemente a concentrações de etanol e metanol representando $50 \%$ dos metabólitos e ácido butírico em torno de 18\%, mas concentrações de ácido propiônico abaixo de 1,2 mmol.L ${ }^{-1}(10 \%)$. A partir de U6, é possível notar variações nas concentrações de ácido propiônico e metanol, com a concentração de ácido lático se tornando significante em U2.

Os maiores valores de $\mathrm{YH}_{2}$ ocorreram a partir do dia 330, com flutuações em

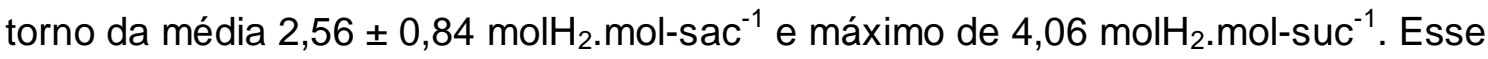
período pode ser considerado estacionário instável, conforme de Bailey \& Ollis (1986), sendo observadas concentrações de etanol de 6,76 \pm 1,66 mmol.L ${ }^{-1}$ e a maior concentração ácido lático $\left(3,60 \pm 2,32 \mathrm{mmol}^{-1} \mathrm{~L}^{-1}\right)$, mas baixas concentrações de ácido propiônico e metanol. Dong et al. (2011) encontraram valor similar de $\mathrm{YH}_{2}(\mathrm{ao}$ redor de 2,8 $\mathrm{molH}_{2} \cdot \mathrm{mol}_{-\mathrm{sac}^{-1}}$ ) em experimento com reator UASB alimentado com substrato sintético a base de sacarose. O reator foi inoculado com lodo granular metanogênico mesofílico e operado à $55^{\circ} \mathrm{C}$ e TDH de $12 \mathrm{~h}\left(\mathrm{COV}\right.$ de $\left.20 \mathrm{gCOD} \cdot \mathrm{L}^{-1} \cdot \mathrm{d}^{-1}\right)$. O ácido butírico foi o principal PMS, e o ácido propiônico apresentou baixa porcentagem.

Zhao et al. (2008) operaram reator UASB a $30^{\circ} \mathrm{C}$, variando o $\mathrm{TDH}$ de 3 à $30 \mathrm{~h}$. O reator foi inoculado com lodo de planta de tratamento de efluente de produção de citrato. Como no presente estudo, esses autores também não encontraram efeito 
significativo do TDH em $\mathrm{YH}_{2}$. Com COV de $21.2 \mathrm{gCOD} \cdot \mathrm{h}^{-1} \cdot \mathrm{L}^{-1}$,os autores obtiveram $\mathrm{YH}_{2}$ de 1,62 $\mathrm{molH}_{2} \cdot \mathrm{mol}_{-\mathrm{sac}^{-1}}$, próximo ao valor médio de toda a fase U2. O ácido butírico foi o PMS mais significante, seguido de etanol. Sob condições mesofílicas $\left(38^{\circ} \mathrm{C}\right)$, $\mathrm{Yu}$ and $\mathrm{Mu}$ (Yu \& Mu, 2006) operaram um reator UASB por 3 anos usando efluente a base de sacarose. $O$ inóculo foi proveniente e UASB tratando efluente de fábrica de citrato e o valor máximo de $\mathrm{YH}_{2}$ foi 2,88 $\mathrm{molH}_{2} \cdot \mathrm{mol}_{-} \mathrm{sac}^{-1}$ obtido ao submeter o reator à COV de $7,11 \mathrm{gCOD} \cdot \mathrm{h}^{-1} \cdot \mathrm{L}^{-1}$ (TDH de $18 \mathrm{~h}$ ).

Como o reator UASB com TDH $2 \mathrm{~h}$ apresentou aumento na concentração de ácido lático e, conforme Kongjan \& Angelidaki (2010), é um sinal de sobrecarga no sistema, o reator UASB não foi operado com TDH de $0,5 \mathrm{~h}$ como as outras configurações.

5.1.3. Influência do TDH na operação do reator tubular com leito empacotado

O processo de auto inoculação foi eficiente para formação de biomassa no reator tubular com leito empacotado em temperatura termofílica independentemente do TDH. Mesmo com a prévia fermentação do substrato sintético em condição mesofílica (temperatura ambiente), a conversão de sacarose já na primeira amostragem, dia 13 para TCS2 e dia 2 para TCS0,5, apresentou valores superiores a 50\% (Figura $10 \mathrm{~A}$ e B), pois o período de recirculação permitiu a seleção de bactérias aptas a se desenvolver na faixa termofílica e demais condições ambientais de cada operação. 

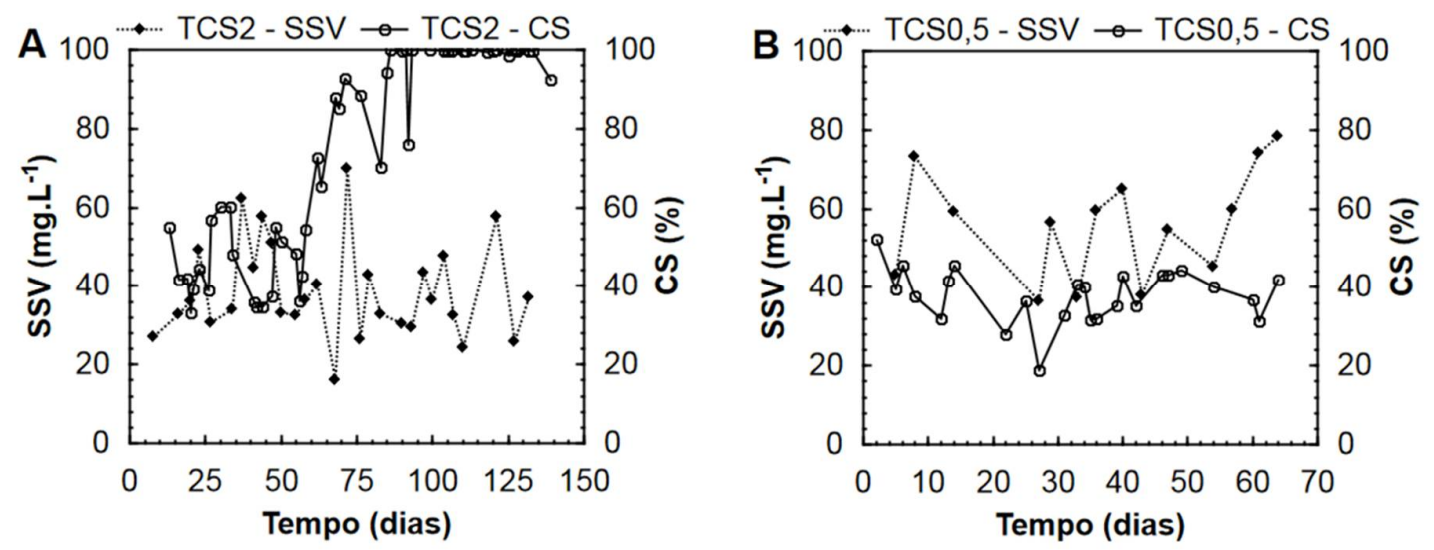

Figura 10 - Conversão de sacarose (CS) e a concentração de sólidos suspensos voláteis (SSV) no efluente no reator tubular com leito empacotado e operado com TDH de $2 \mathrm{~h}(\mathrm{~A})$ e $0,5 \mathrm{~h}(\mathrm{~B})$.

$\mathrm{O} \mathrm{TDH}$, contudo, se mostrou um fator determinante no desempenho do reator ao longo do tempo, conforme Figura 10. Após oscilações na conversão de sacarose no TCS2, a partir do dia 56 o valor de CS aumentou gradativamente até atingir $99,8 \%$ no dia 86 , permanecendo estável, exceto por um declínio para $76,1 \%$ no dia 96. Já o TCS0,5 apresenta pequenas oscilações na CS até o dia 31, com valor mínimo de 18,8\% no dia 27, estabilizando-se em 40,4 \pm 7,6\%. Portanto, a biomassa que se desenvolveu no reator não foi capaz de se adequar a carga orgânica aplicada no TCS0,5 e levou à criação de zonas mortas, indicando que o crescimento e adesão da biomassa que poderia consumir a sacarose remanescente acarretou na diminuição do volume útil do reator e, portanto, do TDH real. Além disso, o escoamento com padrão de mistura completa estabelecido no TCS0,5 exige velocidades de reação mais altas para atingir a mesma eficiência de conversão que um reator em escoamento pistão. A perda de biomassa também foi afetada pelo TDH; apesar de variar em ambas as operações o TCS2 apresentou média 31\% inferior ao TCSO,5.

A influência do TDH no reator tubular em relação à produção de hidrogênio é apresentada na Figura 11. 

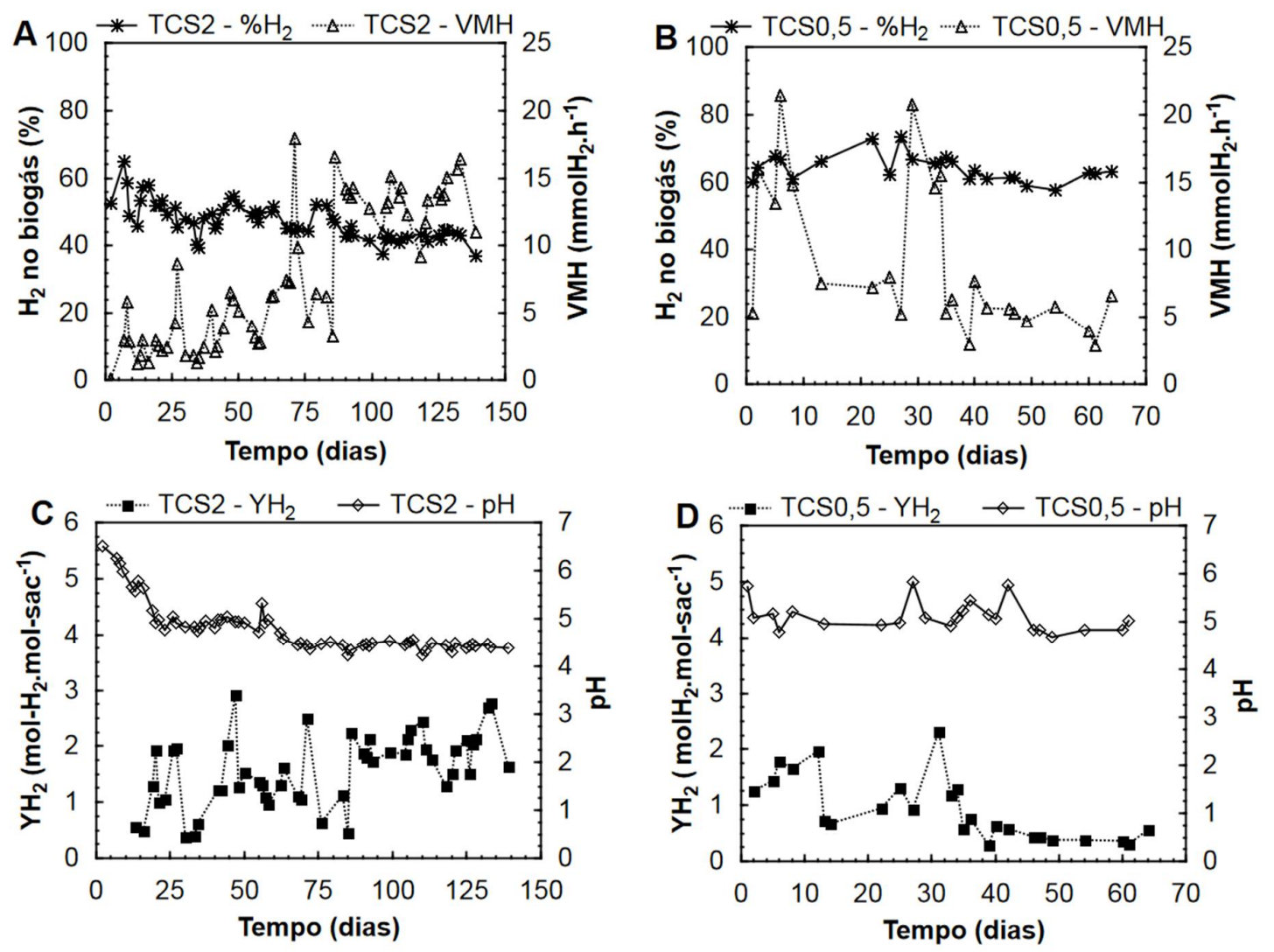

Figura 11 - Visão geral do desempenho do reator TCS na produção de $\mathrm{H}_{2}$. Porcentagem de $\mathrm{H}_{2}$ no biogás e VMH - vazão molar de $\mathrm{H}_{2}(\mathrm{~A}-\mathrm{TDH}$ de $2 \mathrm{~h}$ e $\mathrm{B}-\mathrm{TDH}$ de 0,5h); $\mathrm{YH}_{2}$ - rendimento de $\mathrm{H}_{2}$ e pH (C - TDH de $2 \mathrm{~h}$ e D - TDH de 0,5h)

A produção de $\mathrm{H}_{2}$ no TCS2 acompanhou o comportamento da conversão de sacarose, com oscilações em VMH e $\mathrm{YH}_{2}$ até apresentar valores estáveis após 85 dias, respectivamente, 13,53 \pm 1,75 $\mathrm{mmolH}_{2} \cdot \mathrm{L}^{-1}$ e.1,99 \pm 0,36 $\mathrm{molH}_{2} \cdot \mathrm{mol}_{-\mathrm{sac}^{-1}}$, em condição de $\mathrm{pH} 4,43 \pm 0,08$. A maior $\mathrm{v}_{\text {asc }}$ desenvolvida na condição TSC0,5 permitiu aumento de $46 \%$ no $\mathrm{H}_{2}$ presente no biogás. Porém, com exceção do período inicial e entre os dias 27 e 35, VMH e $\mathrm{YH}_{2}$ obtidas com TSS0,5 foram inferiores à TCS2, conforme apresentado na Tabela 8. O baixo valor de VMH em TCS0,5 poderia ter sido resultado da baixa CS, porém o valor de $\mathrm{YH}_{2}$, obtido pela relação entre $\mathrm{VMH}$ e a velocidade de conversão de sacarose, demonstra que o metabolismo das bactérias nas condições ambientais estabelecidas no reator com TDH de 0,5 foi direcionado para rotas menos eficientes de produção de $\mathrm{H}_{2}$. 
Tabela 8 - Valores médios obtidos para as variáveis da produção de $\mathrm{H}_{2}$ durante o período de estabilidade das operações TCS2 e TCS0,5.

\begin{tabular}{|c|c|c|c|c|c|}
\hline Fase & $\begin{array}{c}\mathrm{VMH}^{(\mathrm{a})} \\
\left(\mathrm{mmolH}_{2} \cdot \mathrm{h}^{-1}\right)\end{array}$ & $\begin{array}{c}\mathrm{PVH}^{(\mathrm{b})} \\
\left(\mathrm{mIH}_{2} \cdot \mathrm{h}^{-1} \cdot \mathrm{L}^{-1}\right)\end{array}$ & $\begin{array}{c}\mathrm{YH}_{2}{ }^{(\mathrm{c})} \\
\left(\mathrm{molH}_{2} \cdot \mathrm{mol}^{-\mathrm{suc}^{-1}}\right)\end{array}$ & $\begin{array}{l}\text { CS }^{(d)} \\
(\%)\end{array}$ & $\begin{array}{c}\mathrm{H}_{2} \text { no } \\
\text { biogás } \\
(\%)\end{array}$ \\
\hline $\operatorname{TCS}^{(f)}$ & $13,53 \pm 1.74$ & $\begin{array}{l}106,77 \pm \\
12,75.87\end{array}$ & $1,99 \pm 0,36$ & $\begin{array}{r}98,33 \\
\pm 5,22\end{array}$ & $\begin{array}{c}42,69 \pm \\
2,21\end{array}$ \\
\hline $\operatorname{TCS} 0,5^{(g)}$ & $5,25 \pm 1,43$ & $\begin{array}{c}63,70 \pm \\
16,25\end{array}$ & $0,48 \pm 0,14$ & $\begin{array}{r}38,13 \\
\pm 5,02\end{array}$ & $\begin{array}{c}62,28 \pm \\
22,72\end{array}$ \\
\hline
\end{tabular}

\footnotetext{
(a) Vazão molar de $\mathrm{H}_{2}$;

(b) Produção volumétrica de $\mathrm{H}_{2}$;

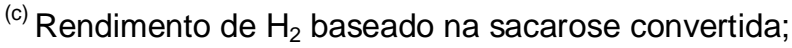

(d) Porcentagem de sacarose convertida;

(e) Porcentagem de $\mathrm{H}_{2}$ no biogás;

(f) Reator tubular com leito empacotado operando com TDH de $2 \mathrm{~h}$ e COV $24 \mathrm{~g} D Q O \cdot \mathrm{L}^{-1} \cdot \mathrm{d}^{-1}-\mathrm{n}=23$, exceto para $\mathrm{YH}_{2}$ e CS $(\mathrm{n}=22)$;

(g) Reator tubular com leito empacotado operando com TDH de 0,5h e COV 96g DQO. $L^{-1} \cdot d^{-1}-n=12$.
}

O rendimento global de biomassa produzida por TCS0,5 atingiu o valor de 0,071 gSSV.g-sac ${ }^{-1}$, enquanto que na operação de TCS2 o rendimento global foi 0,027 gSSV.g-sac ${ }^{-1}$, e a biomassa encontrada no reator ao final da operação foi $31 \%$ menor, mesmo operando por 139 dias, enquanto que o TCS0,5 operou 64 dias. Todavia, a estimativa de produção e perda de biomassa foi realizada por meio dos sólidos suspensos voláteis, não sendo possível diferenciar biomassa de exopolímeros, que poderiam ter sido produzidos em quantidade superior pelas bactérias em TSS0,5 para se manterem no reator.

Ao analisar os PMS produzidos no reator tubular com leito empacotado (Figura 12), pode-se notar que o TDH de $0,5 \mathrm{~h}$ inibiu a solventogênese, rota principal na operação do TCS2 durante a estabilidade. O TCS2 a partir do dia 20 já presentava $\mathrm{pH}$ inferior a 5,0, e no dia 68 atingiu 4,5, quando a concentração de etanol se encontrava em torno de $5 \mathrm{mmol} . \mathrm{L}^{-1}$, com aumento contínuo, chegando a $9,18 \mathrm{mmol} \mathrm{L}^{-1}$ e representando $59,36 \pm 4,05 \%$ dos PMS. Conforme literatura (Barton, 2005), o decréscimo do pH causado pela produção de ácidos como acético e butírico, por exemplo, induz o metabolismo de bactérias do consórcio microbiano à produção de solventes, de forma a impedir a acidificação maior do sistema. 

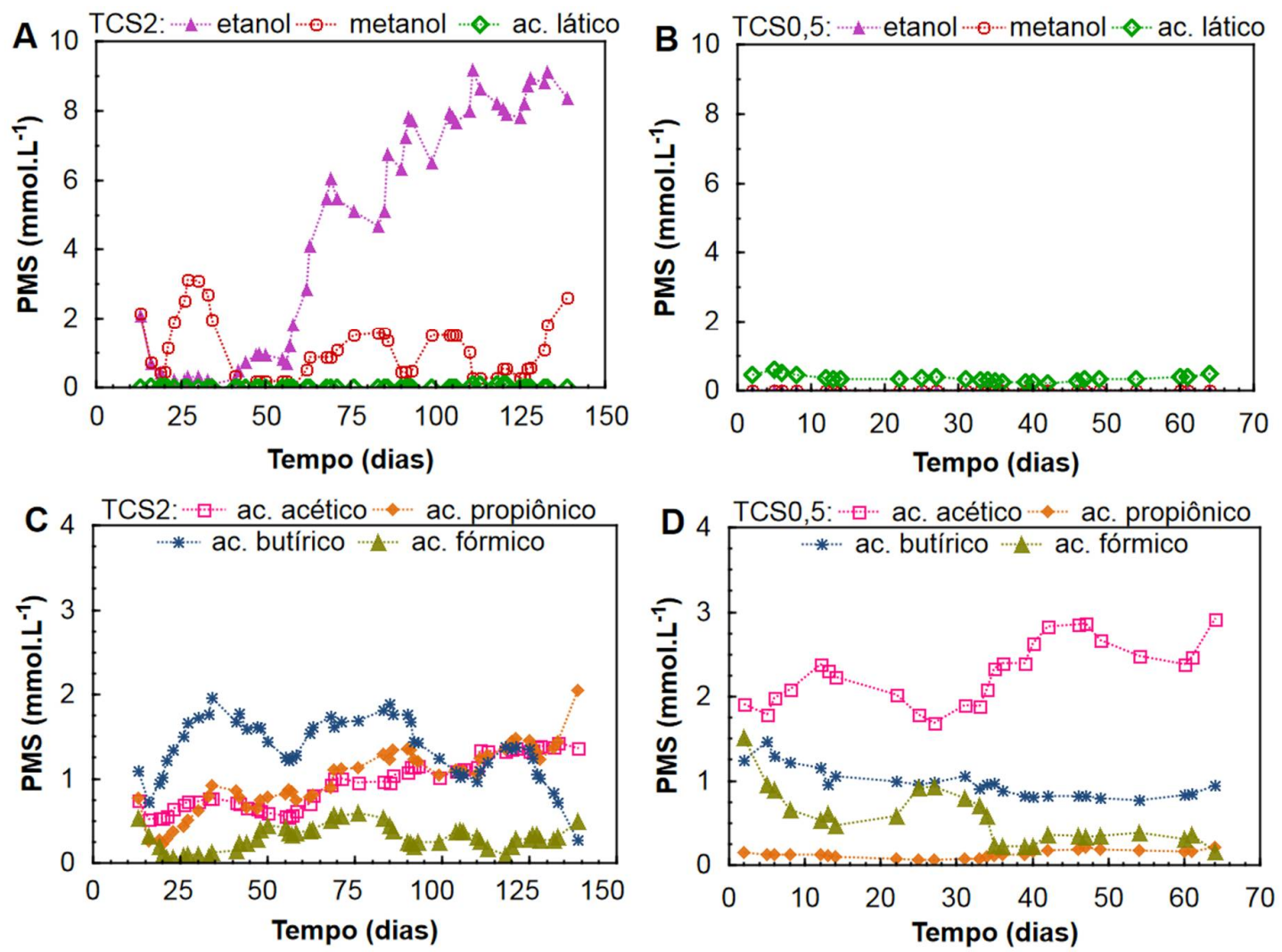

Figura 12 - Concentração dos produtos metabólicos solúveis (PMS) produzidos no reator tubular com leito empacotado e TDH de $2 \mathrm{~h}$ (TCS2) e 0,5h (TCS).

Assim como verificado no reator UASB, o aumento da $\mathrm{V}_{\text {asc }}$ em TSS0,5 promoveu o aumento da transferência do $\mathrm{H}_{2}$ para a fase gasosa. No entanto, ao contrário de U2, as variáveis relacionadas à produtividade diminuíram. Apesar do ácido acético ser a rota mais eficiente para a produção de $\mathrm{H}_{2}$ e ter representado 47,2 $\pm 8,0 \%$ dos PMS em TCS0,5, o baixo rendimento indica que a rota provável para a produção desse ácido foi a homoacetogênese. Uma das hipóteses para a ocorrência da homoacetogênese é a alta COV, que permitiu a maior produção de microrganismos, ter resultado na diminuição da relação substrato/microrganismos, levando as bactérias à alterar seu metabolismo para o crescimento autotrófico.

A homoacetogênese foi identificada em diversos estudos sobre a produção de $\mathrm{H}_{2}$, mas a formas de inibi-la ainda não estão definidas (Saady, 2013). Embora tenha sido verificada em TCS0,5, a operação em temperatura termofílica parece ter sido suficiente para inibir o consumo de $\mathrm{H}_{2}$ para a produção do ácido acético em TCS2, 
visto que Fontes Lima, Moreira, \& Zaiat, (2013) e Penteado, Lazaro, Sakamoto, \& Zaiat (2013) verificaram a queda de $\mathrm{H}_{2}$ devido à homoacetogênese em reatores mesofílicos com leito empacotado, TDH de $2 \mathrm{~h}$ e COV de $24 \mathrm{~g} \cdot \mathrm{L}^{-1} \cdot \mathrm{d}^{-1}$, utilizando substrato sintético a base de sacarose (Lima et al., 2013; Penteado et al., 2013). Os valores máximos encontrados por Fontes Lima, Moreira, \& Zaiat, (2013) e Penteado,

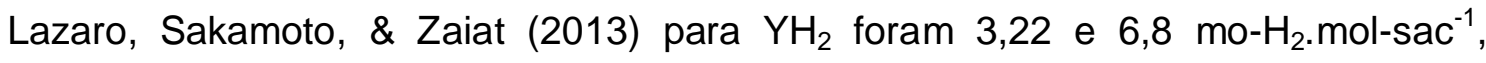
respectivamente, contudo os processos não foram estáveis e $\mathrm{YH}_{2}$ decresceram até valores próximos a zero.

5.1.4. Influência do TDH na operação do reator tubular sem leito empacotado

Ao operar o reator tubular na ausência de material suporte com os mesmos TDH aplicados no TCS, testou-se a hipótese de o próprio fluxo pistonado estabelecido no reator ser capaz de manter biomassa suficiente para converter a sacarose, porém sem o acúmulo excessivo de microrganismos, como observado em TCS0,5, visto que a diminuição da relação substrato/microrganismos tem sido apontada como possível causa da mudança do metabolismo de bactérias produtoras de $\mathrm{H}_{2}$ para a rota homoacetogênica. Além disso, buscou-se a redução da limitação à transferência do $\mathrm{H}_{2}$ produzido para o biogás, como verificado em TCS2.

Conforme é possível visualizar na Figura 13, a CS em TSS apresentou oscilações tanto com TDH de $2 \mathrm{~h}$ quanto de $0,5 \mathrm{~h}$, apresentando estabilidade a partir dos dias 68 e 66 dias, respectivamente. Não houve diferença estatística entre as eficiências de CS, com valores médios de 34,58 \pm 4,87 e 37,00 $\pm 2,42 \%$ para TSS2 e TSS0,5, respectivamente, com perda de biomassa quase duas vezes maior em TSS0,5. 

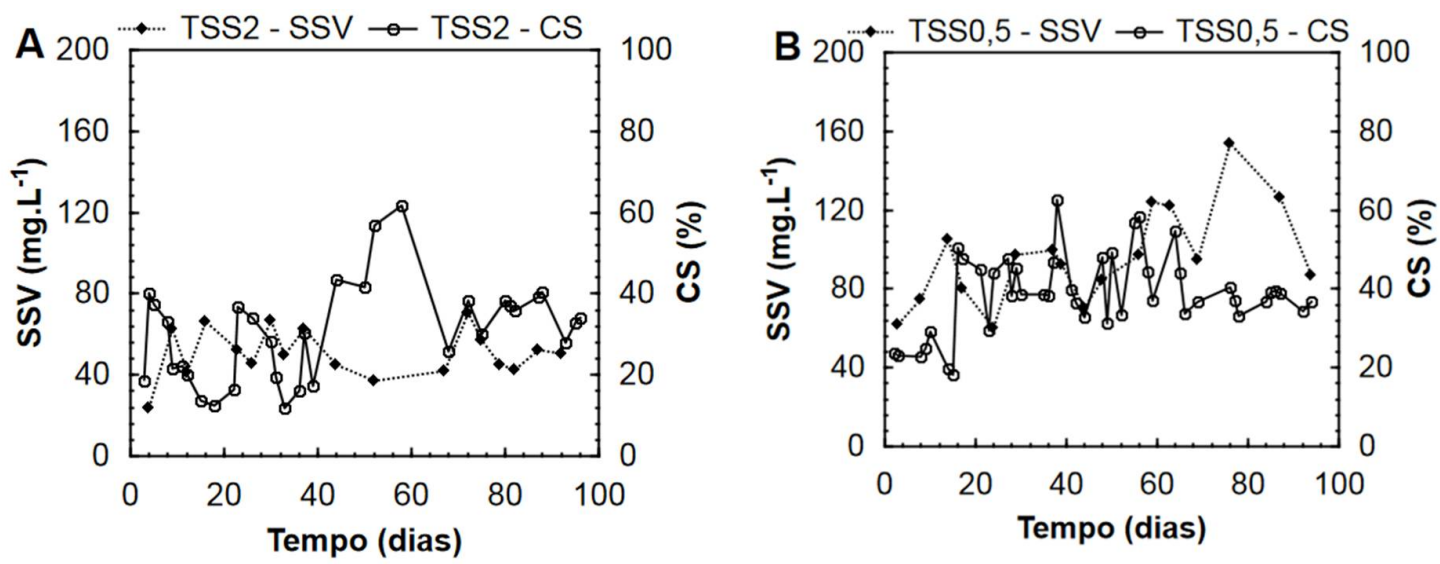

Figura 13 - Conversão de sacarose (CS) e concentração de sólidos suspensos voláteis (SSV) no efluente do reator tubular sem suporte e operado com TDH de $2 \mathrm{~h}$ (A) e $0,5 \mathrm{~h}(\mathrm{~B})$.

A perda de biomassa, no entanto, apresentou estabilidade apenas em TSS2, sendo $92 \%$ inferior a média obtida para TSS0,5. Ao final do experimento, o rendimento global de biomassa produzida em TSS0,5 (0,122 gSSV.g-sac $\left.{ }^{-1}\right)$, foi apenas 33\% superior a TSS2, 0,092 gSSV.g-sac ${ }^{-1}$ e a quantidade de biomassa remanescente ao final das operações foi $66 \%$ superior em TSS2, mesmo com apenas 2 dias a mais de operação.

Ao se observar a Figura 14, pode-se concluir que a estabilidade obtida por TSS0,5 na CS não é refletida na produção de $\mathrm{H}_{2}$. Após significativa queda na VMH para $1,01 \mathrm{mmolH}_{2} \cdot \mathrm{L}^{-1}$ no dia 14 , no qual houve aumento da perda de biomassa, 0 reator aumentou a produção de $\mathrm{H}_{2}$ a partir do dia 21, porém apresentou apenas uma fase estacionária com instabilidade. Uma vez que o modelo de escoamento de TSS0,5 se aproximou de reator de mistura completa (ao final do experimento seu $\mathrm{N}$ foi igual a 7), a possível causa da instabilidade foi a perda de sólidos. 

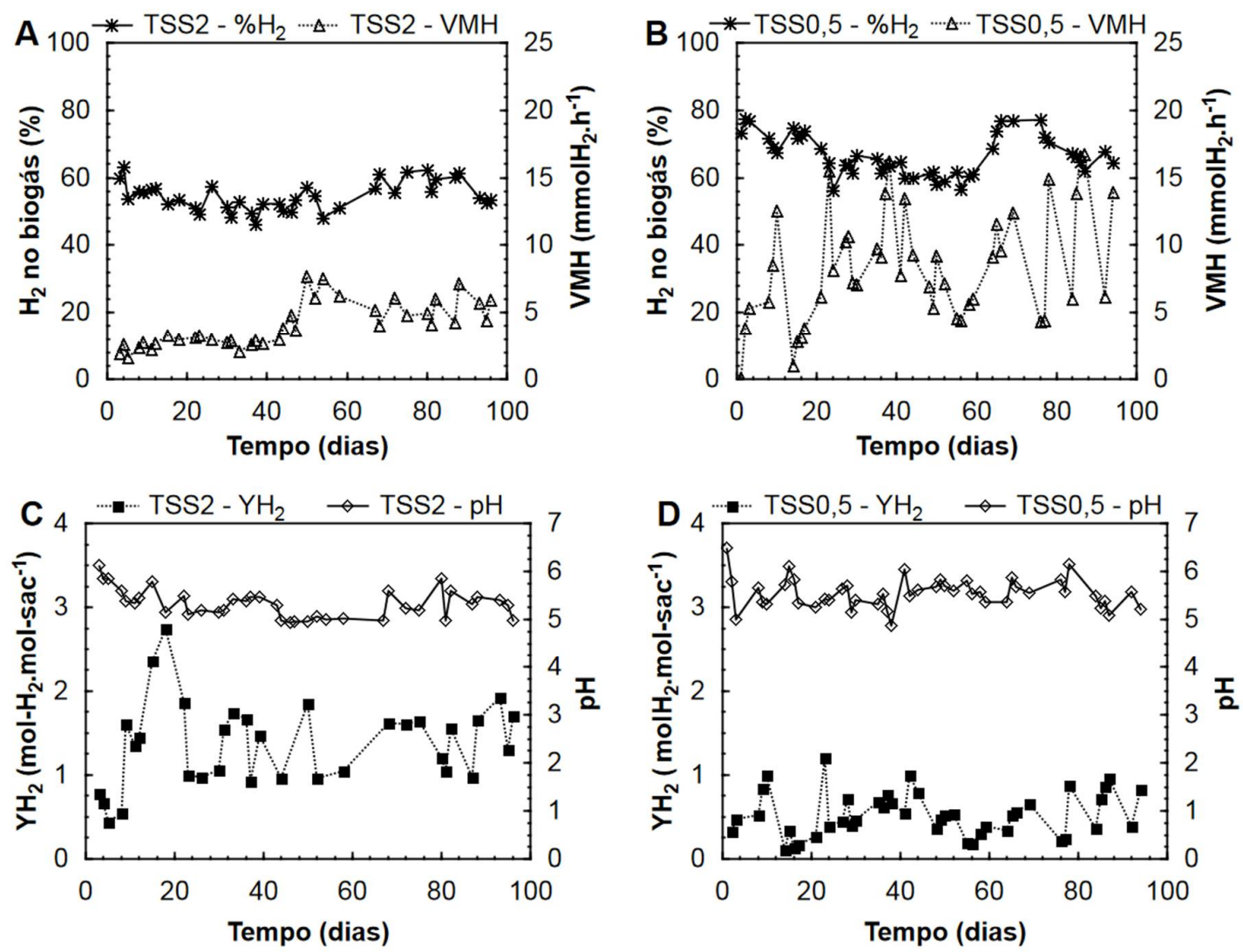

Figura 14 - Visão geral do desempenho do reator TSS na produção de $\mathrm{H}_{2}$. Porcentagem de $\mathrm{H}_{2}$ no biogás e VMH - vazão molar de $\mathrm{H}_{2}(\mathrm{~A}-\mathrm{TDH}$ de $2 \mathrm{~h}$ e $\mathrm{B}-\mathrm{TDH}$ de $0,5 \mathrm{~h}) ; \mathrm{YH}_{2}$ - rendimento de $\mathrm{H}_{2}$ e pH (C - TDH de $2 \mathrm{~h}$ e D - TDH de 0,5h)

No caso do TSS2, a estabilidade também é observada na $\mathrm{VMH}$, demonstrando que a velocidade de crescimento de biomassa e sua adesão no fundo e paredes do reator entrou em equilíbrio com a perda de biomassa. Os valores médios para as variáveis de produção de $\mathrm{H}_{2}$ para TSS2 e TSS0,5, na fase estacionária, são apresentados na Tabela 9. 
Tabela 9 - Valores médios obtidos para as variáveis da produção de $\mathrm{H}_{2}$ durante o período de estabilidade para TSS2 e durante toda a operação de TSS0,5.

\begin{tabular}{|c|c|c|c|c|c|}
\hline Fase & $\begin{array}{c}\mathrm{VMH}^{(\mathrm{a})} \\
\left(\mathrm{mmolH}_{2} \cdot \mathrm{h}^{-1}\right)\end{array}$ & $\begin{array}{c}\mathrm{PVH}^{(\mathrm{b})} \\
\left(\mathrm{mLH}_{2} \cdot \mathrm{h}^{-1} \cdot \mathrm{L}^{-1}\right)\end{array}$ & $\begin{array}{c}\mathrm{YH}_{2}{ }^{(\mathrm{c})} \\
\left(\mathrm{molH}_{2} \cdot \mathrm{mol}^{\left.-\mathrm{suc}^{-1}\right)}\right.\end{array}$ & $\begin{array}{l}\operatorname{CS}^{(d)} \\
(\%)\end{array}$ & $\begin{array}{c}\mathrm{H}_{2} \text { no } \\
\text { biogás } \\
(\%) \\
(\%)\end{array}$ \\
\hline TSS2 $^{(f)}$ & $5,22 \pm 1,01$ & $32,51 \pm 6,86$ & $1,36 \pm 0,43$ & $\begin{array}{c}34,58 \pm \\
4,87\end{array}$ & $\begin{array}{c}58,04 \pm \\
3,71\end{array}$ \\
\hline TSSO, $5^{(\mathrm{g})}$ & $10,81 \pm 4,84$ & $58,56 \pm 20,59$ & $0,61 \pm 0,27$ & $\begin{array}{c}37,00 \pm \\
2,42 \\
\end{array}$ & $\begin{array}{c}69,65 \pm \\
5,39 \\
\end{array}$ \\
\hline $\begin{array}{l}\text { (a) Vazão m } \\
\text { (b) Produçã } \\
\text { (c) Rendime } \\
\text { (d) Porcenta } \\
\text { (e) Porcenta } \\
\text { (f) Reator tu } \\
\text { (g) Reator tl }\end{array}$ & $\begin{array}{l}\text { lar de } \mathrm{H}_{2} ; \\
\text { volumétrica de } \mathrm{H}_{2} \text {; } \\
\text { to de } \mathrm{H}_{2} \text { baseado } \mathrm{n} \\
\text { gem de sacarose cc } \\
\text { gem de } \mathrm{H}_{2} \text { no biogá } \\
\text { oular sem material s } \\
\text { bular sem material }\end{array}$ & $\begin{array}{l}\text { la sacarose convertic } \\
\text { nvertida; } \\
\text { s; } \\
\text { uporte operando cor } \\
\text { suporte operando co }\end{array}$ & $\begin{array}{l}\text { da; } \\
\text { m TDH de } 2 \mathrm{~h} \text { e COV } 24 \mathrm{~g} \\
\mathrm{~m} \text { TDH de } 0,5 \mathrm{~h} \text { e COV } 9\end{array}$ & DQO.L. $L^{-1}$. & $\begin{array}{l}=11 \\
-n=11\end{array}$ \\
\hline
\end{tabular}

Da mesma forma que quando o leito empacotado foi utilizado, o aumento da mistura causado pela diminuição do TDH para $0,5 \mathrm{~h}$ permitiu a produção de biogás com teor de $\mathrm{H}_{2}$ estatisticamente superior. No entanto, a rota utilizada pelo consórcio microbiano em TSS2 para a fermentação da sacarose foi mais eficiente em relação a produção de $\mathrm{H}_{2}$. Não houve diferença estatisticamente significante entre os valores de $\mathrm{VMH}$ de TSS2 e TSS0,5, resultando em $\mathrm{YH}_{2}$ significativamente superior em TSS2.

A produção de PMS por TSS é apresentada na Figura 15 e demonstra que a menor eficiência de TSS0,5 se deve a produção de PMS com alto consumo de $\mathrm{H}_{2}$. Apesar de inibir a produção de ácido propiônico, o metanol foi produzido em maior concentração em TSS0,5 quando comparado com TSS2: 4,62 \pm 0,65 e 1,67 \pm 0,16 mmol. $\mathrm{L}^{-1}$, respectivamente. Além disso a produção de ácido acético foi $43 \%$ superior em TSS2. 

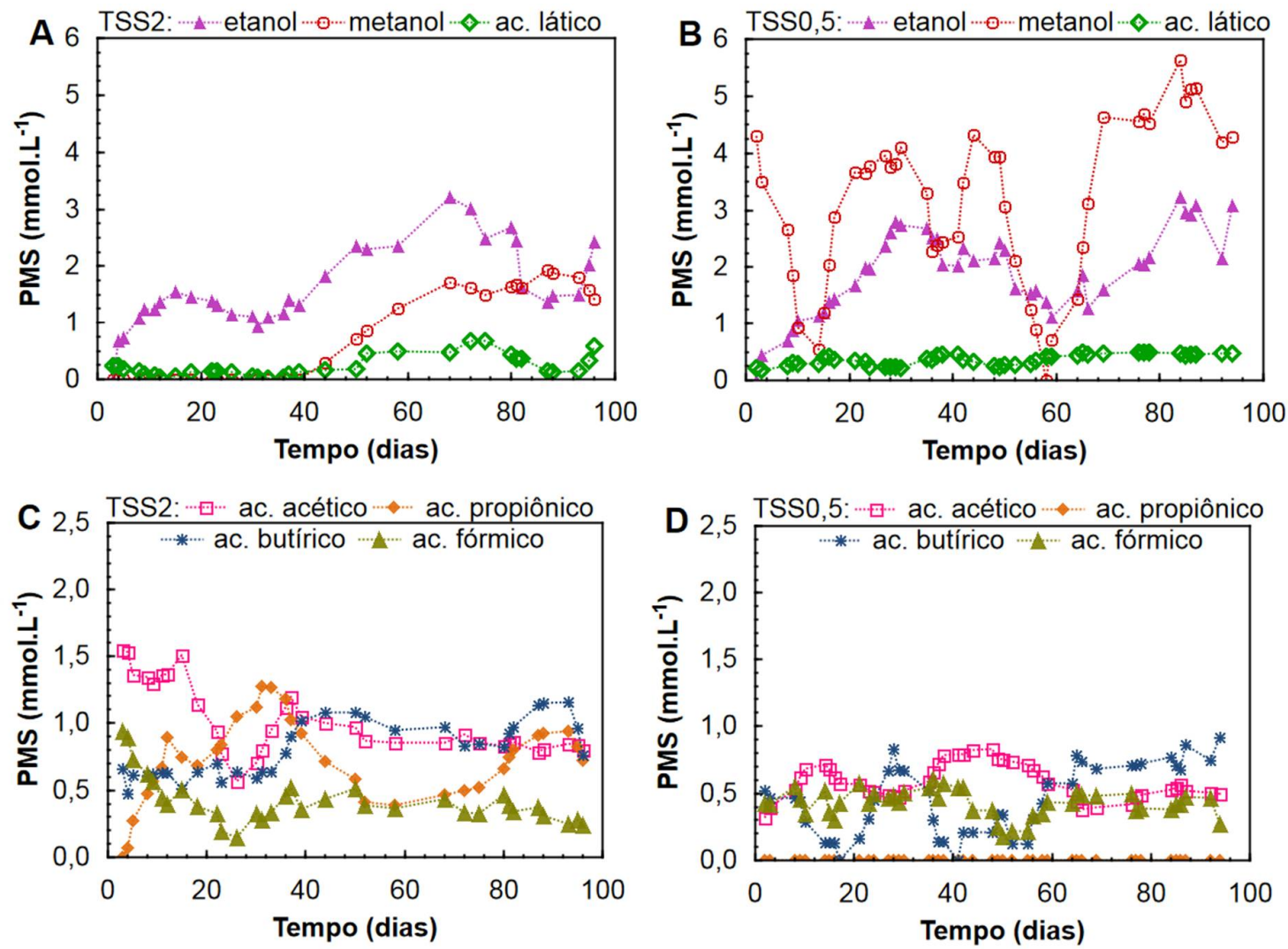

Figura 15 - Concentração dos produtos metabólicos solúveis (PMS) produzidos no reator tubular sem material suporte e TDH de $2 \mathrm{~h}$ (TSS2) e 0,5h (TSS).

Ambas as condições apresentaram produção de ácido lático, característica de estresse causado à comunidade microbiana. Além disso, a presença de ácido fórmico, intermediário gerado durante a quebra do piruvato e que pode ser consumido para a produção de $\mathrm{H}_{2}$, pode indicar contato insuficiente entre as bactérias e o substrato, durante a realização desta etapa, sendo assim, uma característica do tipo de reator independente do TDH aplicado.

\subsubsection{Influência do tipo de reator na produção de hidrogênio}

Os três tipos de reatores utilizados no presente trabalho (UASB, TCS e TSS) foram operados com TDH de $2 \mathrm{~h}$. Apesar da origem do inóculo do reator UASB ter sido diferente, lodo de UASB metanogênico termofílico de planta de tratamento de vinhaça, enquanto os reatores TCS e TSS foram inoculados através do processo de autoinoculação, a condição U2 foi iniciada após 285 dias de operação do reator 
UASB, conferindo assim características acidogênicas à biomassa. Para comparar a influência do tipo de reator, foram construídos gráficos o tipo box-plot (

Figura 16A, B e C) utilizando dados de porcentagem de $\mathrm{H}_{2}, \mathrm{PVH}$ e $\mathrm{YH}_{2} \mathrm{e}$ gráfico de colunas com as médias de PMS obtidos durante os períodos de estabilidade nos reatores TCS e TSS, e referente a operação do reator UASB a partir do dia 330, período considerado estacionário para $\mathrm{YH}_{2}$.
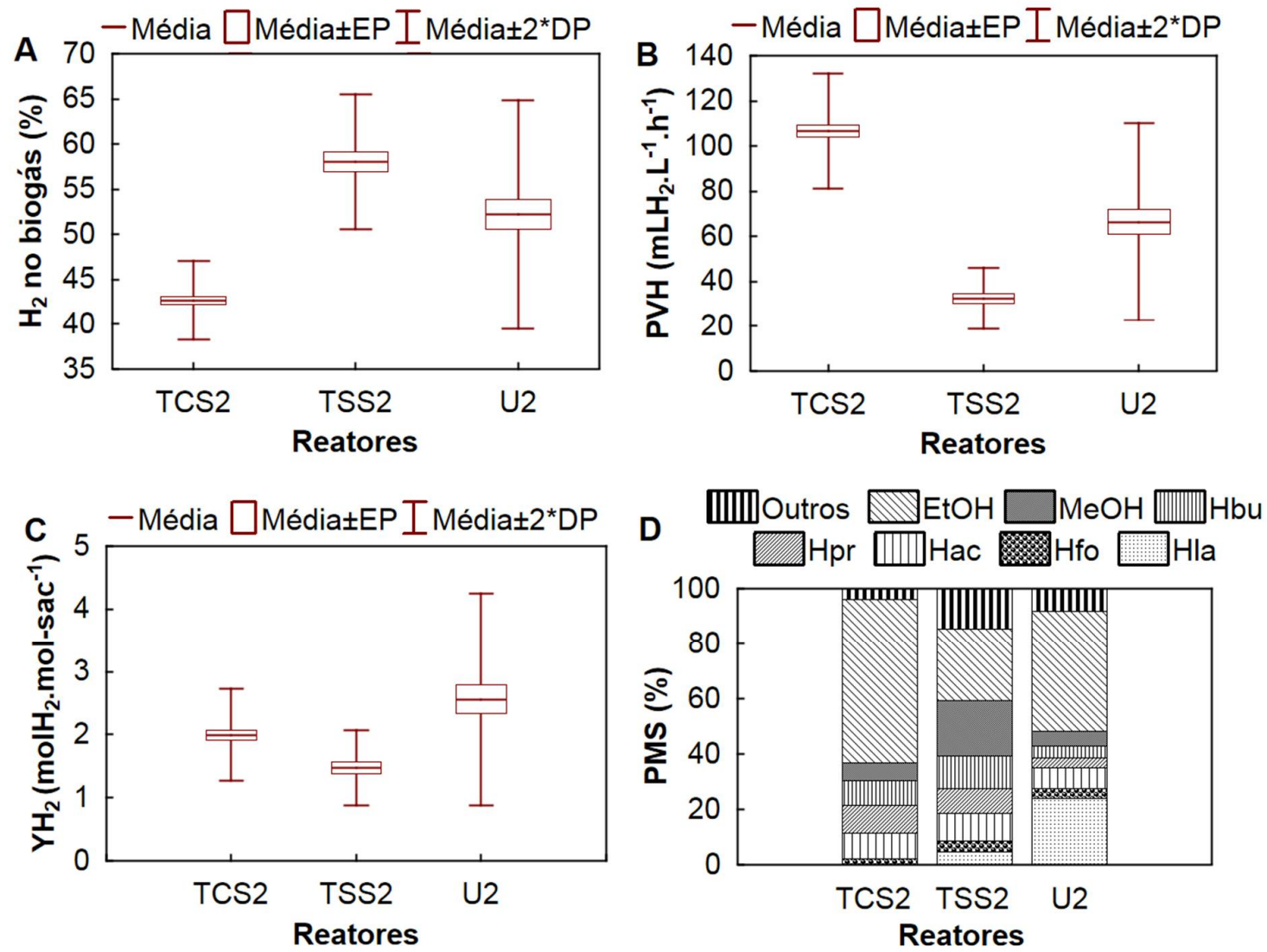

Figura 16 - Principais variáveis obtidas com os reatores operados com TDH de $2 \mathrm{~h}$ : $\mathrm{A}$ - porcentagem de $\mathrm{H}_{2}$ no biogás; $\mathrm{B}-\mathrm{PVH}$, produção volumétrica de $\mathrm{H}_{2} ; \mathrm{C}-\mathrm{YH}_{2}$, rendimento de $\mathrm{H}_{2}$; D - PMS, produto metabólico solúvel: $\mathrm{EtOH}$ (entanol), $\mathrm{MeOH}$ (metanol), Hbu (ácido butírico), Hpr (ácido propiônico), Hac (ácido acético), Hfo (ácido fórmico), Hla (ácido lático).

Conclui-se a partir da Figura 16 que a presença de material suporte dificultou a transferência do $\mathrm{H}_{2}$ para o biogás, conferindo ao TCS a menor porcentagem de $\mathrm{H}_{2}$ no biogás. Entre as configurações com lodo autoimobilizado, não houve diferença estatística em relação à composição do biogás. No entanto, a PVH do TCS2 foi estatisticamente superior às obtidas com as outras configurações, sendo $228 \%$ 
superior à TSS2 e $61 \%$ superior à U2, a qual foi $104 \%$ superior à TSS2. Em relação ao rendimento de produção de $\mathrm{H}_{2}$, representado pela variável $\mathrm{YH}_{2}$, o TCS2 também se mostrou superior à TSS2, porém estatisticamente igual a U2, o qual não pode ser considerado estatisticamente diferente de TSS2. O etanol foi o principal PMS em todas as configurações, porém em menor porcentagem em U2 e TSS2, nos quais as rotas de produção de ácido lático e metanol, respectivamente, foram significativas resultando em valores inferiores de $\mathrm{YH}_{2}$.

Um dos fatores que pode ter contribuído para a instabilidade no U2, verificado na Figura 16 pela ampla faixa interquartil, foi o fato do biogás não ser liberado de forma constante e sim formar bolhas que se acumulavam no interior do leito de lodo até expandirem ao tamanho mínimo para sua liberação, além da dificuldade de manter a vazão constante, devido ao aumento gradativo da perda de carga pelo aumento na concentração do lodo.

Os gráficos box-plot e de colunas (Figura 17) também foram construídos para as configurações operadas com TDH de $0,5 \mathrm{~h}$, com dados da fase estacionária de TCS0,5 e TSS0,5. Foi possível observar que apesar de a solventogênse ter sido a rota principal em TSS0,5, com alta produção de metanol (44,6 $\pm 2,48 \%$ dos PMS produzidos), enquanto que em TCS0,5 foi verificada a produção majoritária de ácidos, com ácido acético representando $57,1 \%$ dos ácidos, a presença de material suporte não teve efeito sobre a produção de $\mathrm{H}_{2}$, visto que não houve diferença

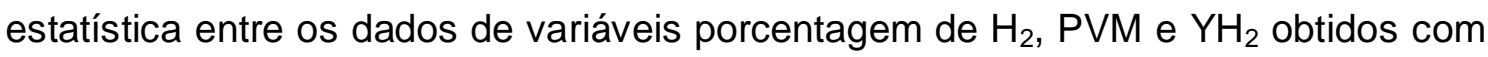
as configurações analisadas. 

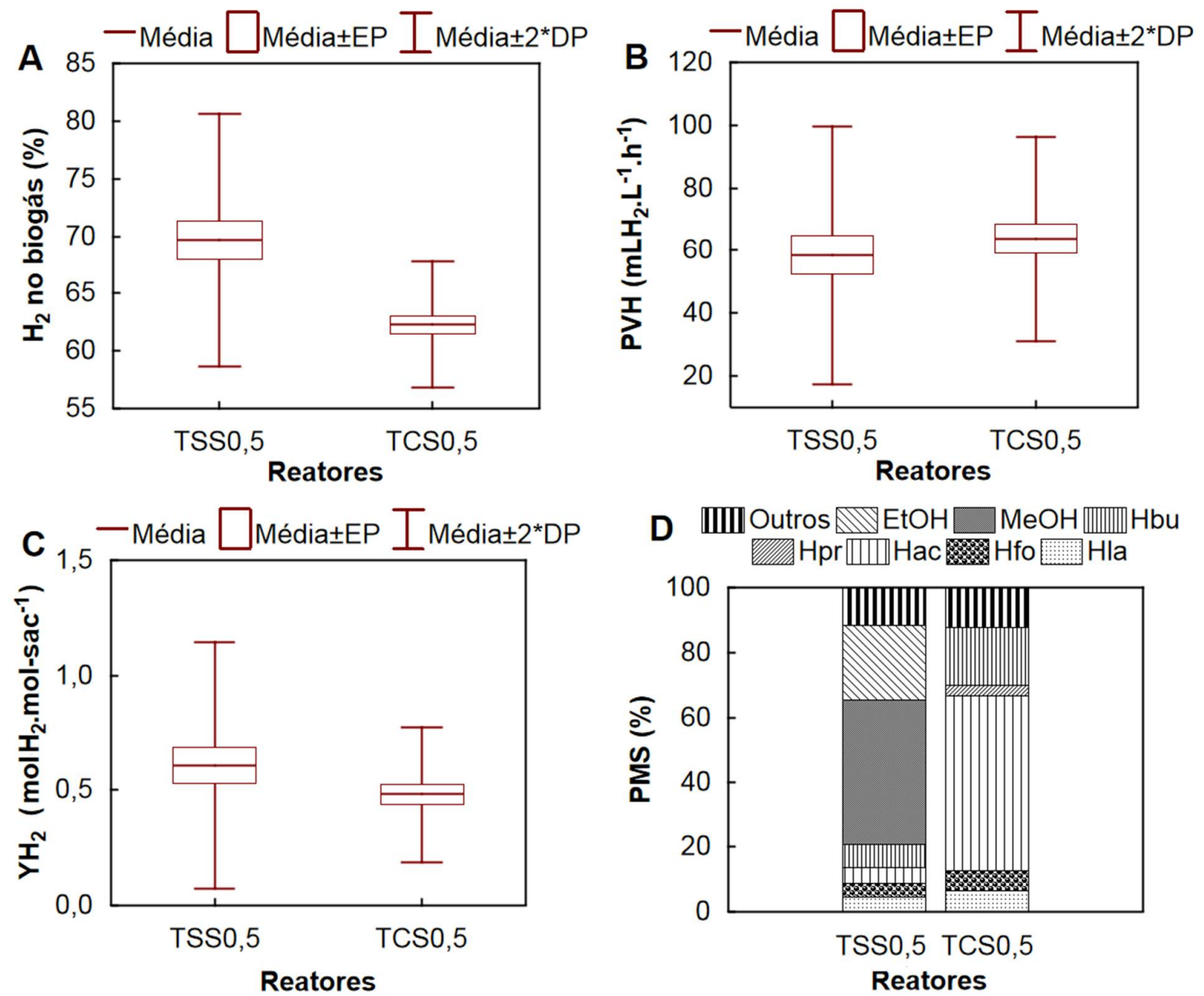

Figura 17 - Principais variáveis obtidas com os reatores operados com TDH de 0,5h: A - porcentagem de $\mathrm{H}_{2}$ no biogás; $\mathrm{B}-\mathrm{PVH}$, produção volumétrica de $\mathrm{H}_{2} ; \mathrm{C}-\mathrm{YH}_{2}$, rendimento de $\mathrm{H}_{2}$; D - PMS, produto metabólico solúvel: EtOH (entanol), $\mathrm{MeOH}$ (metanol), Hbu (ácido butírico), Hpr (ácido propiônico), Hac (ácido acético), Hfo (ácido fórmico), Hla (ácido lático).

\subsubsection{Considerações sobre rotas metabólicas}

A partir dos dados produção de PMS, foram realizados os cálculos de coeficiente de rendimento de PMS (YPMS), apresentados na Tabela 10. 
Tabela 10 - Valores médios dos coeficientes de rendimento dos PMS (YPMS).

\begin{tabular}{|c|c|c|c|c|c|c|c|}
\hline \multirow{2}{*}{ Fase } & \multicolumn{7}{|c|}{ YPMS (mol.mol-suc ${ }^{-1}$ ) } \\
\hline & $\mathrm{Hla}^{(\mathrm{a})}$ & $\mathrm{Hfo}^{(\mathrm{c})}$ & $\mathrm{Hac}^{(\mathrm{c})}$ & $\mathrm{Hpr}^{(\mathrm{d})}$ & $\mathrm{Hbu}^{(\mathrm{e})}$ & $\mathrm{MeOH}^{(\mathrm{f})}$ & $\mathrm{EtOH}^{(\mathrm{g})}$ \\
\hline $\mathbf{U S U}^{(\mathrm{h})}$ & $\begin{array}{c}0,00 \pm \\
0,01\end{array}$ & $\mathrm{~N} / \mathrm{D}$ & $\begin{array}{c}0,40 \pm \\
0,16\end{array}$ & $\begin{array}{c}0,60 \pm \\
0,21\end{array}$ & $\begin{array}{c}0,47 \pm \\
0,28\end{array}$ & $\begin{array}{c}0,08 \pm \\
0,14\end{array}$ & $\begin{array}{c}0,03 \pm \\
0,04\end{array}$ \\
\hline U12 $2^{(i)}$ & $\begin{array}{c}0,00 \pm \\
0,00\end{array}$ & $\begin{array}{c}0,01 \pm \\
0,01\end{array}$ & $\begin{array}{c}0,24 \pm \\
0,06\end{array}$ & $\begin{array}{c}0,40 \pm \\
0,20\end{array}$ & $\begin{array}{c}0,31 \pm \\
0,15\end{array}$ & $\begin{array}{c}0,58 \pm \\
0,23\end{array}$ & $\begin{array}{c}0,64 \pm \\
0,46\end{array}$ \\
\hline $\mathrm{U} 6^{(\mathrm{j})}$ & $\begin{array}{c}0,00 \pm \\
0,00\end{array}$ & $\begin{array}{c}0,03 \pm \\
0,01\end{array}$ & $\begin{array}{c}0,20 \pm \\
0,05\end{array}$ & $\begin{array}{c}0,34 \pm \\
0,13\end{array}$ & $\begin{array}{c}0,22 \pm \\
0,07\end{array}$ & $\begin{array}{c}0,52 \pm \\
0,30\end{array}$ & $\begin{array}{c}0,95 \pm \\
0,22\end{array}$ \\
\hline$U 2^{(k)}$ & $\begin{array}{c}0,84 \pm \\
0,62\end{array}$ & $\begin{array}{c}0,08 \pm \\
0,05\end{array}$ & $\begin{array}{c}0,28 \pm \\
0,07\end{array}$ & $\begin{array}{c}0,21 \pm \\
0,27\end{array}$ & $\begin{array}{c}0,13 \pm \\
0,04\end{array}$ & $\begin{array}{c}0,11 \pm \\
0,16\end{array}$ & $\begin{array}{c}1,44 \pm \\
0,28\end{array}$ \\
\hline $\operatorname{TCS2}^{(\mathrm{I})}$ & $\begin{array}{c}0,00 \pm \\
0,01\end{array}$ & $\begin{array}{c}0,05 \pm \\
0,02\end{array}$ & $\begin{array}{c}0,20 \pm \\
0,03\end{array}$ & $\begin{array}{c}0,21 \pm \\
0,04\end{array}$ & $\begin{array}{c}0,19 \pm \\
0,05\end{array}$ & $\begin{array}{c}0,14 \pm \\
0,12\end{array}$ & $\begin{array}{c}1,28 \pm \\
0,20\end{array}$ \\
\hline TCS0, $5^{(\mathrm{m})}$ & $\begin{array}{c}0,12 \pm \\
0,03\end{array}$ & $\begin{array}{c}0,11 \pm \\
0,03\end{array}$ & $\begin{array}{c}1,02 \pm \\
0,11\end{array}$ & $\begin{array}{c}0,06 \pm \\
0,01\end{array}$ & $\begin{array}{c}0,33 \pm \\
0,06\end{array}$ & $N / D$ & $\mathrm{~N} / \mathrm{D}$ \\
\hline $\operatorname{TSS2}^{(n)}$ & $\begin{array}{c}0,22 \pm \\
0,12\end{array}$ & $\begin{array}{c}0,18 \pm \\
0,05\end{array}$ & $\begin{array}{c}0,46 \pm \\
0,09\end{array}$ & $\begin{array}{c}0,39 \pm \\
0,11\end{array}$ & $\begin{array}{c}0,51 \pm \\
0,13\end{array}$ & $\begin{array}{c}0,90 \pm \\
0,18\end{array}$ & $\begin{array}{c}1,21 \pm \\
0,48\end{array}$ \\
\hline TSSO, $5^{(0)}$ & $0,14 \pm$ & $\begin{array}{c}0,15 \pm \\
0,05\end{array}$ & $\begin{array}{c}0,21 \pm \\
0,06\end{array}$ & $\mathrm{~N} / \mathrm{D}$ & $\begin{array}{c}0,18 \pm \\
0,10\end{array}$ & $\begin{array}{c}1,25 \pm \\
0,58\end{array}$ & $\begin{array}{c}0,79 \pm \\
0,25\end{array}$ \\
\hline
\end{tabular}

\footnotetext{
(a) Ácido lático na fase líquida;
}

(b) Ácido fórmico na fase líquida;

(c) Ácido acético na fase líquida;

(d) Ácido propiônico na fase líquida;

(e) Ácido butírico na fase líquida;

${ }^{(f)}$ Metanol na fase líquida;

(g) Etanol na fase líquida;

(h) Partida UASB durante toda a operação $(n=17)$;

(i) UASB TDH de $12 \mathrm{~h}$ e COV $4 \mathrm{gDQO} \cdot \mathrm{L}^{-1} \cdot \mathrm{d}^{-1}$ durante toda a operação $(\mathrm{n}=69)$;

(i) UASB TDH de 6 h e COV 8 gDQO. $L^{-1} \cdot d^{-1}$ durante toda a operação $(n=31)$;

(k) UASB TDH de 2 h e COV 24 gDQO. $L^{-1} \cdot d^{-1}$ durante toda a operação $(n=25)$.

(l) Tubular com leito empacotado e TDH de $2 \mathrm{~h}$ e COV $24 \mathrm{gDQO} \cdot \mathrm{L}^{-1} \cdot \mathrm{d}^{-1}$, durante a fase estável $(\mathrm{n}=22)$;

(m) Tubular com leito empacotado e TDH de $0,5 \mathrm{~h}$ e COV $96 \mathrm{~g}$ DQO. $\mathrm{L}^{-1} \cdot \mathrm{d}^{-1}$, durante a fase estável $(\mathrm{n}=$ 12);

(n) Tubular sem suporte e TDH de 2 h e COV $24 \mathrm{gDQO} \cdot \mathrm{L}^{-1} \cdot \mathrm{d}^{-1}$, durante a fase estável $(\mathrm{n}=11)$;

(o) Tubular sem suporte e TDH de 0,5 h e COV $96 \mathrm{gDQO} \cdot \mathrm{L}^{-1} \cdot \mathrm{d}^{-1}$, a partir do dia $21(\mathrm{n}=35)$;

A produção de ácido lático está associada a condições de estresse a comunidade microbiana. Por ser um ácido fraco, pode ser produzido como uma resposta do metabolismo de certas bactérias à acidificação do meio (Barton, 2005). Assim, o aumento da COV na condição U2 com queda no $\mathrm{pH}$ estimulou a produção de ácido lático. A produção de ácido lático pode seguir as rotas homofermentativa (Equação 30) ou heterofermentativa (Equação 31), sendo a última em conjunto com a produção de etanol (Madigan, Martinko, Stahl, \& Clark, 2012). 
Ácido lático via piruvato

$\mathrm{CH}_{3} \mathrm{CH}_{2} \mathrm{COOH}+\mathrm{NADH}+\mathrm{H}^{+} \rightarrow \mathrm{CH}_{3} \mathrm{CHOHCOOH}+\mathrm{NAD}$ Equação 30

Ácido lático via heterofermentação

$\mathrm{C}_{12} \mathrm{H}_{22} \mathrm{O}_{11} \rightarrow 2 \mathrm{CH}_{3} \mathrm{CHOHCOOH}+2 \mathrm{CH}_{3} \mathrm{CH}_{2} \mathrm{OH}+2 \mathrm{CO}_{2}$ Equação 31

A solventogênse também pode ser estimulada por queda no $\mathrm{pH}$ e outras condições de estresse microbiano. O metanol foi detectado em células inativas de bactérias metanotróficas que, sob condições de estresse, como limitação de nitrogênio de razão $\mathrm{NADH} / \mathrm{NAD}^{+}$superior a necessária para o crescimento, consomem 1 mol de $\mathrm{CO}_{2}$ e 2 mols de $\mathrm{H}_{2}$ para produzir Poli- $\beta$-Hidroxibutirato (PHB). Em períodos de privação de substrato, o PHB é então clivado em um processo que consome mais $1 \mathrm{~mol}$ de $\mathrm{H}_{2}$ e resulta em metanol como produto final (Xin, Zhang, Zhang, Xia, \& Li, 2007). A equação geral de produção de metanol é apresentada como Equação 32.

Metanol via consumo de $\mathrm{H}_{2}$ e $\mathrm{CO}_{2}$

$\mathrm{CO}_{2}+3 \mathrm{H}_{2} \rightarrow \mathrm{CH}_{3} \mathrm{OH}+\mathrm{H}_{2} \mathrm{O}$ Equação 32

Levando em consideração os valores de rendimento de PMS (YPMS) ao longo de todo o período e usando a estequiometria das Equações 1-6, 8-11 e 30-32, foi realizado o balanço global entre a produção potencial de $\mathrm{H}_{2}$ e $\circ \mathrm{H}_{2}$ utilizado na formação dos metabólitos reduzidos, para testar as possíveis rotas metabólicas estabelecidas nos reatores e conhecer o $\mathrm{YH}_{2}$ teórico.

Para os cálculos, foi considerado $1 \mathrm{~mol}$ de sacarose consumida. Assim, a produção de $\mathrm{H}_{2}$ resultou da reoxidação de 4 mols de $\mathrm{NADH}$ produzidos durante a glicólise e a produção de $\mathrm{H}_{2}$ conjunta com a produção de acetil-CoA, necessária para a formação dos ácidos acético e butírico e etanol. Assumiu-se a rota PFL para produção de acetil-CoA, nos casos em que o ácido fórmico foi detectado no efluente. Também foi realizado o balanço de DQO entre a DQO afluente e a DQO efluente 
correspondente à concentração de $\mathrm{H}_{2}$, PMS, sacarose não convertida $\mathrm{e}$ concentração de $\mathrm{CH}_{4}$, quando presente no biogás.

Através dos cálculos metabólicos, com resultados da Tabela 11, é possível fazer algumas considerações sobre as rotas metabólicas estabelecidas durante a operação do reatores UASB e tubular com e sem leito empacotado. $\mathrm{YH}_{2}$ experimental em USU foi inferior ao teórico, assim, provavelmente arqueas metanogênicas seguiram utilizaram tanta a rota acetoclástica quanto a hidrogenotrófica para a produção de $\mathrm{CH}_{4}$, sendo possível até $46 \%$ de produção a partir de $\mathrm{H}_{2}$. 
Tabela 11 - Balanço estequiométrico de $\mathrm{H}_{2}$, baseado em 1 mol de sacarose convertida.

\begin{tabular}{|c|c|c|c|c|c|}
\hline Fase & $\begin{array}{c}\text { Produção } \\
\text { potencial de } \mathrm{H}_{2}{ }^{(a)} \\
\left(\text { mol.mol-suc }{ }^{-1}\right)\end{array}$ & $\begin{array}{c}\mathrm{H}_{2} \text { para } \\
\text { metabólitos }^{(\mathbf{b})} \\
\left(\text { mol.mol-suc }^{-1}\right)\end{array}$ & $\begin{array}{l}\mathrm{YH}_{2} \text { teórico } \\
(\mathrm{mol}) \\
\left(\mathrm{molmol}^{-1} \mathrm{suc}^{-1}\right)\end{array}$ & $\begin{array}{c}\text { Balanço } \mathrm{YH}_{2 \text { theo }} \mathrm{e} \\
\mathrm{YH}_{2 \text { medido }}{ }^{(\mathrm{d})} \\
\left.\text { (mol.mol-suc }^{-1}\right)\end{array}$ & $\begin{array}{c}\text { Balanço de } \\
\text { DQO }^{(\mathrm{e})} \\
(\%)\end{array}$ \\
\hline $\mathbf{U S U}^{(\mathrm{t})}$ & 6,40 & 2,46 & 3,94 & 3,56 & $106 \pm 8$ \\
\hline $\mathrm{U} 12^{(\mathrm{g})}$ & 5,51 & 4,45 & 0,97 & $-0,13$ & $103 \pm 9$ \\
\hline $\mathrm{U} 6^{(\mathrm{h})}$ & 5,60 & 4,58 & 1,00 & 0,16 & $111 \pm 12$ \\
\hline U2 ${ }^{(i)}$ & 5,15 & 3,05 & 1,12 & $-0,61$ & $95 \pm 10$ \\
\hline TCS2 $^{(\mathrm{j})}$ & 5,60 & 3,47 & 2,18 & 0,60 & $93 \pm 21$ \\
\hline $\operatorname{TCS} 0,5^{(\mathrm{k})}$ & 5,10 & 1,10 & 4,47 & 3,54 & $132 \pm 16$ \\
\hline TSS2 $^{(1)}$ & 6,78 & 5,21 & 1,14 & $-0,23$ & $116 \pm 10$ \\
\hline TSSO, $5^{(\mathrm{m})}$ & 5,60 & 5,52 & $-0,63$ & $-1,16$ & $109 \pm 9$ \\
\hline
\end{tabular}

(a) $\mathrm{H}_{2}$ potencialmente produzido em conjunto com a produção de acetil CoA e reoxidação da NADH produzida durante a glicólise;

(b) $\mathrm{H}_{2}$ utilizado na produção dos ácidos lático, propiônico e butírico, metanol e etanol;

(c) Balanço entre $\mathrm{H}_{2}$ produzido e consumido na produção dos produtos finais reduzidos;

(d) . Balanço entre $\mathrm{YH}_{2}$ teórico e $\mathrm{YH}_{2}$ obtido nos experimentos $\left(\mathrm{YH}_{2 \text { theo }}-\mathrm{YH}_{2 \text { medido }}\right)$;

(e) Balanço entre DQO efluente e DQO efluente de $\mathrm{H}_{2}, \mathrm{CH}_{4}, \mathrm{SMP}$ e sacarose não convertida;

(f) Partida UASB (para balanço de DQO $n=17$ );

(g) UASB TDH de $12 \mathrm{~h}$ e COV $4 \mathrm{gDQO} \cdot \mathrm{L}^{-1} \cdot \mathrm{d}^{-1}$, durante todo o período (para balanço de DQO $\mathrm{n}=69$ )

(h) UASB TDH de $6 \mathrm{~h}$ e COV $8 \mathrm{gDQO} \cdot \mathrm{L}^{-1} \cdot \mathrm{d}^{-1}$, durante todo o período (para balanço de DQO $\mathrm{n}=31$ );

(i) UASB TDH de $2 \mathrm{~h}$ e COV $24 \mathrm{gDQO} \cdot \mathrm{L}^{-1} \cdot \mathrm{d}^{-1}$, durante todo o período (para balanço de DQO $\mathrm{n}=25$ ).

(j) Tubular com leito empacotado e TDH de $2 \mathrm{~h}$ e COV $24 \mathrm{gDQO} \cdot \mathrm{L}^{-1} \cdot \mathrm{d}^{-1}$, durante todo o período (para balanço de DQO todo o período $\mathrm{n}=54$ );

(k) Tubular com leito empacotado e TDH de 0,5 h e COV $96 \mathrm{gDQO} \cdot \mathrm{L}^{-1} \cdot \mathrm{d}^{-1}$, durante todo o período (para balanço de DQO $\mathrm{n}=26$ );

(l) Tubular sem suporte e TDH de $2 \mathrm{~h}$ e COV $24 \mathrm{gDQO} \cdot \mathrm{L}^{-1} \cdot \mathrm{d}^{-1}$, durante todo o período (para balanço de DQO $\mathrm{n}=34$ );

(m) Tubular sem suporte e TDH de $0,5 \mathrm{~h}$ e COV $96 \mathrm{gDQO} \cdot \mathrm{L}^{-1} \cdot \mathrm{d}^{-1}$, durante todo o período (para balanço de DQO $\mathrm{n}=45$ ); 
Em USU, quando o reator UASB ainda apresentava produção de $\mathrm{CH}_{4}, 0$ menor $\mathrm{YH}_{2}$ obtido experimentalmente (937\% inferior ao teórico) foi resultado da metanogênese hidrogenotrófica (Equação 33), que poderia representar até $46 \%$ da produção de metano. Em TCS0,5 foi obtido $\mathrm{YH}_{2} 380 \%$ inferior ao possível teoricamente e, como houve a expressiva produção de ácido acético, cuja rota seria a mais favorável para a produção de $\mathrm{H}_{2}$, presume-se que a produção desse ácido tenha ocorrido através da homoacetogênese (Equação 12). Nessa condição, até $73 \%$ da produção de ácido acético poderia ser proveniente do consumo de $\mathrm{H}_{2}$.

$$
\mathrm{CO}_{2}+4 \mathrm{H}_{2} \rightarrow \mathrm{CH}_{4}+2 \mathrm{H}_{2} \mathrm{O} \text { Equação } 33
$$

Nas condições U6 e TCS2, os valores experimentais de $\mathrm{YH}_{2}$ foram apenas 19 e $38 \%$ inferiores aos valores teóricos. Como parte do $\mathrm{H}_{2}$ permanece dissolvido na fase líquida, mesmo em reatores termofílicos (Zhang, Zhang, Chen, \& Zeng, 2012b), e depende do coeficiente de transferência de massa $\left(K_{L} a\right)$, intrínseco de cada reator, não é possível afirmar sobre a ocorrência de homoacetogênese. Além disso, o ácido acético correspondeu a menos de $10 \%$ dos PMS produzidos nessas condições.

Nas condições U12, U2, TSS2 e TSS0,5 o balanço de $\mathrm{YH}_{2}$ foi negativo em, respectivamente, $12,35,17$ e $218 \%$, considerando que todo $\circ \mathrm{H}_{2}$ seria transferido para o biogás. Como exposto na literatura (Donot, Fontana, Baccou, \& SchorrGalindo, 2012; Freitas, Alves, \& Reis, 2011), uma ampla gama de microrganismos são produtores de polissacarídeos para armazenamento interno de carbono e energia, na forma de PHA, ou para proteção externa através de biofilmes, como exopolissacarídeos (EPS). A produção desse polissacarídeos é estimulada pela alta concentração de substrato, nutrientes e aumento da força de cisalhamento no interior do reator. EPS, assim como PHA, podem ser produzidos através da quebra da sacarose. No caso dos PHB, 2 mols de acetil-CoA são necessários e é provável que o excesso de $\mathrm{H}_{2}$ nos dados experimentais venha da produção de acetil Co-A pela clivagem de piruvato, para a produção de polissacarídeos. Considerando essa hipótese, se 5, 62, 88 e $88 \%$ do piruvato remanescente fossem convertidos em acetil-CoA, em U12, U2, TSS2 e TSS0,5, respectivamente, o déficit de $\mathrm{H}_{2}$ seria suprido. 
A porção de sacarose utilizada para crescimento em sistemas termofílicos é baixa. Nas condições U2 e TCS2 esse valor correspondeu a 5 e $7 \%$, respectivamente, conforme os balanços de DQO. Nas outras fases, a DQO efluente foi superior à afluente, especialmente em TCS0,5, o que pode ser resultado do consumo de $\mathrm{CO}_{2}$ dissolvido para a produção de metanol ou para a homoacetogênese.

\subsubsection{Definição da melhor configuração}

A escolha da melhor configuração passa pela análise de vários critérios. A porcentagem de $\mathrm{H}_{2}$, por exemplo, é um aspecto importante quando o destino do $\mathrm{H}_{2}$ é a geração de eletricidade utilizando células a combustível, pois esse tipo de equipamento exige $\mathrm{H}_{2}$ com pureza acima de $99,99 \%$ de $\mathrm{H}_{2}$, e como as principais técnicas de purificação do gás utilizado envolvem o processo de adsorção, quanto maior a pureza do biogás produzido maior a vida útil do material adsorvente. Em casos cuja finalidade é a geração contínua de eletricidade através de células, as variáveis $\mathrm{PVM}$ e $\mathrm{YH}_{2}$ passam a ter maior peso para estimar a demanda de energia por hora que o sistema poderá suprir. Sendo assim, mesmo que apresentem menor porcentagem de $\mathrm{H}_{2}$ no biogás, configuração com $\mathrm{PVM}$ e $\mathrm{YH}_{2}$ superiores podem se tornar mais adequadas.

Portanto, a escolha da configuração passa a depender da finalidade que será dada ao biogás. A apresentação resumida dos principais resultados para definição da melhor configuração é feita através das Tabela 12 eTabela 13. A Tabela 12 indica se houve estabilização do reator durante a operação e o principal PMS produzido. $\mathrm{Na}$ Tabela 13 foi atribuída a posição em ordem crescente para médias de $\mathrm{PVH}, \mathrm{YH}_{2}$ e porcentagem de $\mathrm{H}_{2}$, encontradas em cada operação e considerando as diferenças estatísticas.

As configurações TCS2 e U2 foram as que apresentaram melhor desempenho, apesar de ambas as configurações terem conduzido à rota metabólica solventogênica, com etanol em maior proporção, e apresentado porcentagens inferiores de $\mathrm{H}_{2}$ no biogás. Contudo TCS2 apresentou os maiores valores médios para $\mathrm{PVH}$ e $\mathrm{YH}$ e produção estável de $\mathrm{H}_{2}$, seguido por U2, a qual não apresentou 
estabilidade. Portanto, entre as configurações testadas, a TCS 2 pode ser avaliada como a mais eficiente para produção de $\mathrm{H}_{2}$.

Tabela 12 - Avaliação da estabilidade e principais PMS produzidos nas configurações de reatores testadas no presente estudo.

\begin{tabular}{|c|c|c|}
\hline Condição & Estabilidade & $\begin{array}{c}\text { Principal PMS } \\
(\%)\end{array}$ \\
\hline $\mathbf{U S U}^{(\mathbf{b})}$ & Ausente & $\begin{array}{c}\text { Ác. acético/ ác. butírico } \\
(24,5 / 27,4)\end{array}$ \\
\hline $\mathrm{U} 12^{\text {(c) }}$ & Ausente & Etanol/ metanol $(25,4 / 24,0)$ \\
\hline $\mathrm{UG}^{(\mathrm{d})}$ & Ausente & Etanol $(39,4)$ \\
\hline $\mathrm{U} 2^{(\mathrm{e})}$ & Ausente & Etanol $(43,5)$ \\
\hline $\operatorname{TCS2}^{(\mathrm{f})}$ & Presente & Etanol $(59,3)$ \\
\hline TCSO, $5^{(\mathrm{g})}$ & Presente & Ác. acético $(54,2)$ \\
\hline TSS2 $^{(\mathrm{h})}$ & Presente & Etanol/ metanol $(25,9 / 20,2)$ \\
\hline TSSO, $5^{(i)}$ & Ausente & Metanol $(44,6)$ \\
\hline
\end{tabular}

(a) Principal Produto metabólico solúvel

(b) Partida UASB durante toda a operação $(n=17)$;

(c) UASB TDH de $12 \mathrm{~h}$ e COV 4gDQO. $\mathrm{L}^{-1} \cdot \mathrm{d}^{-1}$ durante toda a operação $(\mathrm{n}=69)$;

(d) UASB TDH de $6 \mathrm{~h}$ e COV $8 \mathrm{gDQO} \cdot \mathrm{L}^{-1} \cdot \mathrm{d}^{-1}$ durante toda a operação $(\mathrm{n}=31)$;

(e) UASB TDH de 2 h e COV 24gDQO. $\mathrm{L}^{-1} \cdot \mathrm{d}^{-1}$, a partir do dia $330(\mathrm{n}=15)$.

(f) Tubular com leito empacotado e TDH de $2 \mathrm{~h}$ e COV $24 \mathrm{gDQO} \cdot \mathrm{L}^{-1} \cdot \mathrm{d}^{-1}$, durante a fase estável $(\mathrm{n}=22)$;

(g) Tubular com leito empacotado e TDH de 0,5 h e COV 96gDQO. $\mathrm{L}^{-1} \cdot \mathrm{d}^{-1}$, durante a fase estável $(\mathrm{n}=$ 12);

(h) Tubular sem suporte e TDH de 2 h e COV $24 \mathrm{gDQO} \cdot \mathrm{L}^{-1} \cdot \mathrm{d}^{-1}$, durante a fase estável $(\mathrm{n}=11)$;

(i) Tubular sem suporte e TDH de 0,5 h e COV 96gDQO. $\mathrm{L}^{-1} \cdot \mathrm{d}^{-1}$, a partir do dia $21(\mathrm{n}=11)$.

Tabela 13 - Avaliação da estabilidade e principais PMS produzidos nas configurações de reatores testadas no presente estudo

\begin{tabular}{|c|c|c|c|}
\hline \multicolumn{4}{|c|}{ Ordenamento das médias ${ }^{(\mathrm{a})}$} \\
\hline Posição & $\mathbf{P V H}^{(b)}$ & $\mathrm{YH}_{2}{ }^{(\mathrm{c})}$ & $\mathrm{H}_{2}$ no biogás ${ }^{(\mathrm{d})}$ \\
\hline 1 & TCS2 & $\mathrm{TCS}^{1}$ & $\mathrm{TSS}_{0,5^{1}}$ \\
\hline 2 & U2/TCS0,5/TSS0,5 & $\mathrm{U} 2^{2}$ & TCSO, $5^{2}$ \\
\hline 3 & TSS2 & TSS2 $^{3}$ & TSS2 $^{3}$ \\
\hline 4 & U6 & U12/U6 & U2 \\
\hline 5 & U12 & TSS0, $5^{1}$ & $\mathrm{U}^{1}$ \\
\hline 6 & USU & TCSO, $5^{2}$ & U12 2 \\
\hline 7 & & USU $^{3}$ & $\operatorname{TCS}^{3}$ \\
\hline 8 & & & USU \\
\hline
\end{tabular}

(a) Ordenamento crescente das médias, considerando significância estatística de 5\%. O subíndice 2 indica que a média é igual as médias com subíndices 1 e 3 , as quais são diferentes entre si; ${ }^{(b)}$

(b) Produção volumétrica de $\mathrm{H}_{2}$;

(c) Rendimento de $\mathrm{H}_{2}$ baseado na sacarose convertida;

(d) Porcentagem de $\mathrm{H}_{2}$ no biogás. 
5.1.8.

Análise microbiológica nos reatores

Como apresentado na Figura 18, o efeito de lavagem (washout) durante USU e a acidificação do ambiente atuaram selecionando a biomassa, uma vez que o inóculo foi apenas $20 \%$ similar às comunidades estabelecidas no reator durante a operação. Além disso, a comunidade estabelecida durante U12, quando houve predominância da acidogênese, apresentou 38\% de similaridade com a população encontrada no final da operação com TDH de $12 \mathrm{~h}$, quando a solventogênese era a rota dominante. Com a estabilização da perda de biomassa depois da partida do reator, pode-se considerar que as condições ambientais determinadas pelo decréscimo do TDH para $6 \mathrm{~h}$ e, em seguida, para $2 \mathrm{~h}$, e as concentrações de PMS no sistema foram os maiores responsáveis pela mudança no consórcio microbiano. Essa mudança aconteceu na mesma intensidade ao se aplicar a mudança de TDH, uma vez que resultou em similaridade de $48 \%$ entre U2 e o agrupamento de U12B, ao final da operação com $\mathrm{TDH}$ de $12 \mathrm{~h}$, e U6, os quais foram $54 \%$ similares.

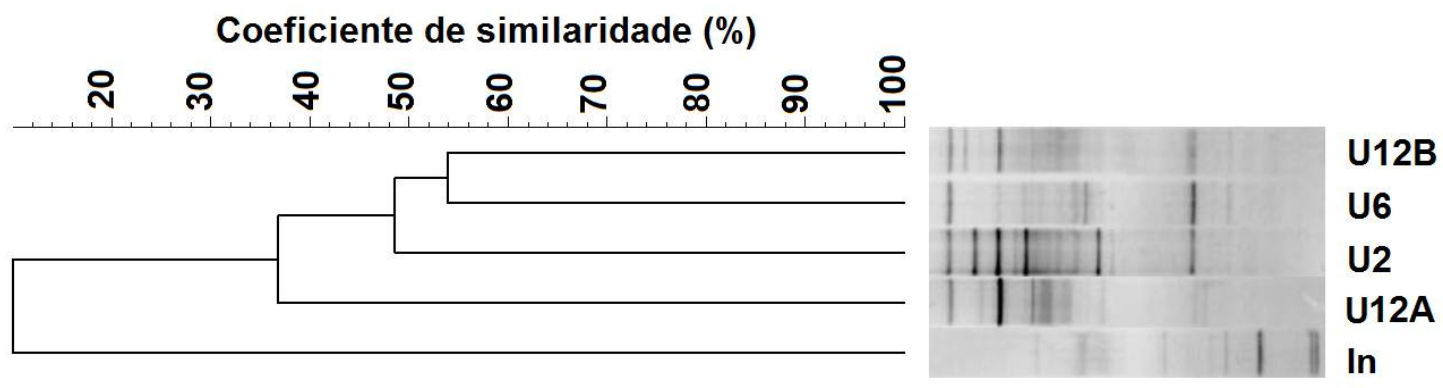

Figura 18 - Agrupamento das comunidades microbianas nas operações do reator UASB: nos dias 110 (U12A), 211 (U12B), 282 (U6) e 366 (U2).

A Figura 19 apresenta o agrupamento entre as comunidades microbianas estabelecidas nas operações do reator tubular com leito empacotado, tanto no leito empacotado (LE: TCS2LE, para TDH de $2 \mathrm{~h}$, e TCS0,5LE para TDH de 0,5 h) quanto no compartimento de acúmulo de biomassa (CA: TCS2CA, para TDH de $2 \mathrm{~h}$, e TCS0,5CA para TDH de 0,5 h), nas operações sem material suporte e ainda a operação do reator UASB com TDH de $2 \mathrm{~h}$. 


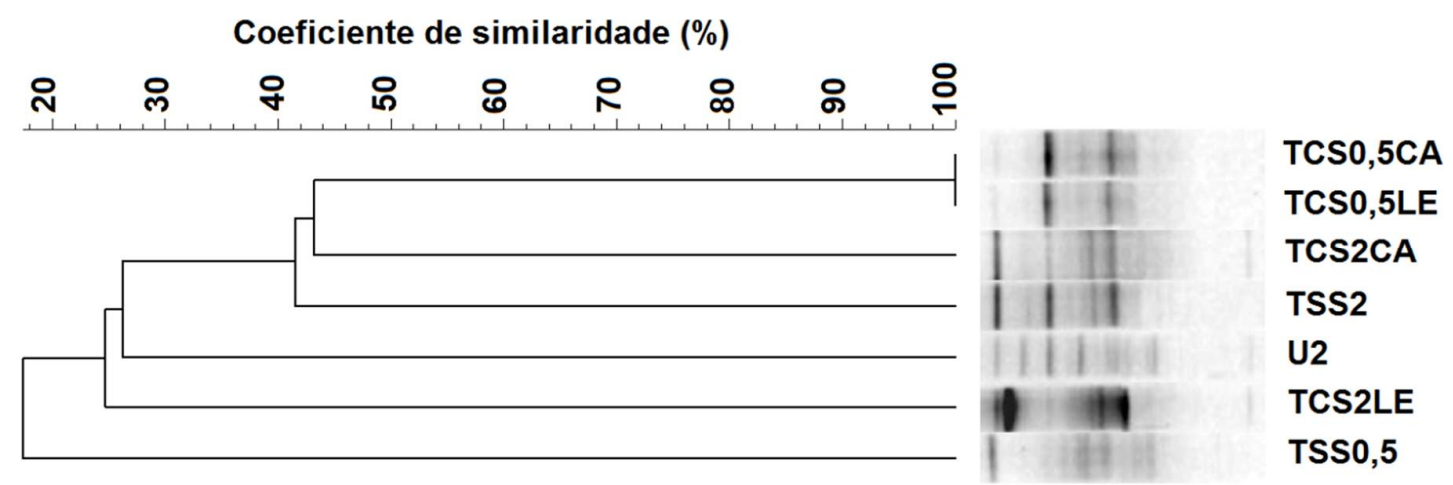

Figura 19 - Agrupamento das comunidades microbianas nas operações dos reatores tubular com leito empacotado (TCS), tanto no leito empacotado (LE: TCS2LE, para TDH de $2 \mathrm{~h}$, e TCS0,5LE para TDH de 0,5 h) quanto no compartimento de acúmulo de biomassa (CA: TCS2CA, para TDH de 2, e TCS0,5CA para TDH de 0,5);tubular sem material suporte (TSS) e UASB com TDH de $2 \mathrm{~h}$ (U2).

A característica de mistura perfeita do reator TCS0,5 é confirmada pela similaridade de $100 \%$ entre o leito do reator e o compartimento de acúmulo. O TDH mais alto, consequente menor $\mathrm{v}_{\text {asc }}$, e diferentes condições ambientais desenvolvidas no reator, teve efeito seletivo sobre a comunidade microbiana no reator, sendo confirmado pela baixa similaridade entre TSS2 e TSS0,5, 18\%, e TCS0,5 e TCS2CA $40 \%$. Quando TCS0,5 foi comparado com o TCS2LE o coeficiente caiu para apenas 24\%. O escoamento no reator pistonado estabelecido em TCS2 acarretou na diferenciação entre leito e compartimento de acúmulo, como é visto pela similaridade de $24 \%$ entre TCS2LE e TCS2AC, $2 \%$ inferior à similaridade do reator UASB, inoculado com lodo de origem metanogênica, em relação ao mesmo TCS2AC.

Assim, as diferentes composições de PMS encontradas nas operações dos reatores foram consequência dos diferentes consórcios microbianos adaptados a cada condição testada.

\subsection{Etapa 2 - Verificação da condição nutricional ótima}

A matriz utilizada no experimento baseado no arranjo Planckett-Burman e os valores de $\mathrm{VMPH}$ e $\mathrm{YH}_{2}$ obtidos nos ensaios são apresentados na Tabela 14. O 
teste ANOVA mostrou, com nível de significância de 5\%, que há três fatores cujos efeitos são significativos: $\mathrm{Fe}^{+2}, \mathrm{Ni}^{+2}$ e $\mathrm{C}: \mathrm{N}: \mathrm{P}$.

Tabela 14 - Matriz Plackett-Burman e os valores de VPH e $\mathrm{YH}_{2}$ para cada ensaio.

\begin{tabular}{|c|c|c|c|c|c|c|c|c|}
\hline \multicolumn{7}{|c|}{ Níveis dos fatores } & \multicolumn{2}{|c|}{ Variáveis } \\
\hline $\begin{array}{l}C: N: \\
P\end{array}$ & $\mathrm{Co}_{2}^{+}$ & $\mathrm{Fe}^{2+}$ & $\underset{+}{\mathrm{Mg}^{2}}$ & $\mathrm{Ni}^{2+}$ & $\mathrm{Se}^{2+}$ & $\begin{array}{c}\mathrm{Zn}^{2} \\
+\end{array}$ & $\begin{array}{c}\text { VMPH } \\
\left.\left(\mathrm{mmol}^{-1}\right)^{-1}\right)\end{array}$ & $\begin{array}{c}\mathrm{YH}_{2} \\
\left(\mathrm{molH}_{2} \cdot \text { molsac }^{-1}\right)\end{array}$ \\
\hline-1 & -1 & -1 & 1 & 1 & 1 & -1 & $\begin{array}{c}0,023 \pm \\
0,004\end{array}$ & $1,12 \pm 0,34$ \\
\hline-1 & -1 & 1 & 1 & -1 & -1 & 1 & $\begin{array}{c}0,033 \pm \\
0,012\end{array}$ & $1,29 \pm 0,02$ \\
\hline-1 & 1 & -1 & -1 & 1 & -1 & 1 & $\begin{array}{c}0,029 \pm \\
0,004\end{array}$ & $0,90 \pm 0,17$ \\
\hline-1 & 1 & 1 & -1 & -1 & 1 & -1 & $\begin{array}{c}0,037 \pm \\
0,004\end{array}$ & $1,39 \pm 0,36$ \\
\hline 0 & 0 & 0 & 0 & 0 & 0 & 0 & $\begin{array}{c}0,018 \pm \\
0,001\end{array}$ & $0,68 \pm 0,06$ \\
\hline 1 & -1 & -1 & -1 & -1 & 1 & 1 & $\begin{array}{c}0,011 \pm \\
0,011\end{array}$ & $0,73 \pm 0,10$ \\
\hline 1 & -1 & 1 & -1 & 1 & -1 & -1 & $\begin{array}{c}0,026 \pm \\
0,012\end{array}$ & $1,83 \pm 0,34$ \\
\hline 1 & 1 & -1 & 1 & -1 & -1 & -1 & $\begin{array}{c}0,007 \pm \\
0,003\end{array}$ & $0,65 \pm 0,02$ \\
\hline 1 & 1 & 1 & 1 & 1 & 1 & 1 & $\begin{array}{c}0,019 \pm \\
0,03\end{array}$ & $1,56 \pm 0,23$ \\
\hline
\end{tabular}

Foi estimado que o aumento da concentração de $\mathrm{Fe}^{+2}$ do nível inferior para o superior eleva em 4 e 6\%, respectivamente, os valores de $\mathrm{VMPH}$ e $\mathrm{YH}_{2}$, da mesma forma, o aumento na concentração de $\mathrm{Ni}^{2+}$ proporciona aumento de $3 \%$ em $\mathrm{YH}_{2}$, como é possível ser visualizado nos diagramas de Pareto (Figura 20A e B). Os mesmos diagramas mostram que os valores da relação $\mathrm{C}: \mathrm{N}: \mathrm{P}$ influenciam de forma inversa o valor de $\mathrm{VMH}$, permitindo um aumento de $4 \%$ quando $\mathrm{C}: \mathrm{N}: \mathrm{P}$ passa do nível 1 para -1. A inclusão de pontos centrais permitiu, ainda, a avaliação do efeito da curvatura, que na resposta rendimento demonstrou efeito negativo, sinalizando, assim, a existência de um ponto de mínimo significativo na faixa de valores escolhida para os fatores significativos. 

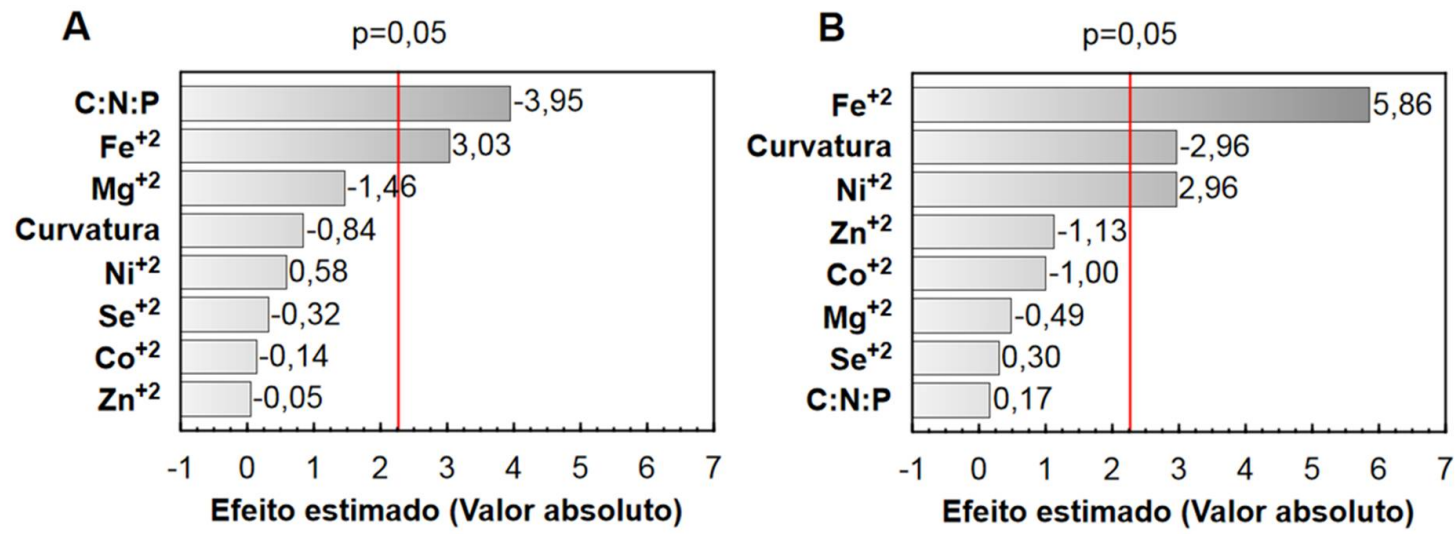

Figura 20 - Diagramas de Pareto mostrando os efeitos de cada nutriente sobre a velocidade molar de produção de $\mathrm{H}_{2}(\mathrm{~A})$ e rendimento de $\mathrm{H}_{2}(\mathrm{~B})$.

A influência dos metais ferro e níquel era esperada, pois, conforme a literatura (Vignais \& Colbeau, 2004), eles compõem o núcleo de diversas enzimas relacionadas aos metabolismos de produção e consumo de $\mathrm{H}_{2}$. A relação $\mathrm{C}: \mathrm{N}: P$ é outro fator de extrema importância para as bactérias. Os elementos carbono, nitrogênio e fósforo fazem parte da composição celular em porcentagens representativas, em geral, 50, 13 e 2,5\% do peso seco sendo, portanto, indispensáveis para o crescimento celular (Madigan et al., 2012). A disponibilidade de nitrogênio e carbono também atua sobre o metabolismo dos microrganismos, podendo alterar as rotas metabólicas utilizadas por eles, bem como induzir à formação de esporos em bactérias com essa capacidade (Madigan et al., 2012).

O planejamento Plackett-Burman permitiu ainda o ajuste de equações lineares de $\mathrm{VMPH}$ e $\mathrm{YH}_{2}$ em função dos fatores significativos, resultando nas Equações 34 e 35.

$$
\begin{gathered}
V M H=0,023-0,007 R_{C: N: P}+0,006 C_{F e+2} \text { Equação } 34 \\
Y H_{2}=1,18-0,33 C_{F e+2}+0,17 C_{N i+2} \text { Equação } 35
\end{gathered}
$$

Essas equações foram utilizadas como diagonal de maior inclinação e, assim, os três fatores significativos $\left(\mathrm{Fe}^{+2}, \mathrm{Ni}^{+2}\right.$ e $\left.\mathrm{C}: \mathrm{N}: \mathrm{P}\right)$ foram utilizados para a próxima etapa, com o objetivo de se aproximar das faixas de concentrações de nutrientes que fornecem o valor ótimo especificamente para cada variável. Como a 
concentração de $\mathrm{Fe}^{+2}$ teve efeito significativo e diretamente proporcional ao aumento das variáveis $\mathrm{VMPH}$ e $\mathrm{YH}_{2}$, mas os demais fatores foram significativos para apenas uma das variáveis, buscou-se a otimização de uma faixa de concentração para cada variável. O planejamento originou as respostas presentes na Tabela 15.

Tabela 15 - Resultados obtidos com o planejamento pelo método da diagonal de maior inclinação.

\begin{tabular}{ccc}
\hline \multirow{2}{*}{ Ensaios } & \multicolumn{2}{c}{ Variáveis } \\
& VMPH $\left(\mathbf{m m o l}_{\mathbf{h}}^{\mathbf{- 1}}\right)$ & $\mathbf{Y H}_{\mathbf{2}}\left(\mathbf{m o l H}_{\mathbf{2}} \cdot \mathbf{m o l}-\mathbf{s a c}^{-\mathbf{1}}\right)$ \\
\hline Centro & $0,031 \pm 0,001$ & $1,75 \pm 0,05$ \\
Centro $+\Delta$ & $0,073 \pm 0,008$ & $1,54 \pm 0,03$ \\
Centro $+2 \Delta$ & $0,057 \pm 0,019$ & $1,46 \pm 0,24$ \\
Centro $+3 \Delta$ & $0,118 \pm 0,004$ & $1,44 \pm 0,02$ \\
Centro $+4 \Delta$ & $0,074 \pm 0,005$ & $1,55 \pm 0,04$ \\
\hline
\end{tabular}

Ao se partir do ponto central, aumentando as concentrações de $\mathrm{Fe}^{2+}$ e $\mathrm{Ni}^{2+} \mathrm{e}$ diminuindo a relação $\mathrm{C}: \mathrm{N}: \mathrm{P}$ não foi observado aumento no valor de $\mathrm{YH}_{2}$ com relação ao teste anterior, sendo o maior valor dessa variável obtido no ponto central. Levando em consideração a VMPH, obteve-se incremento em seu valor até a condição centro $+3 \Delta$, havendo decréscimo na condição centro $+4 \Delta$. Assim, como o maior valor de $\mathrm{YH}_{2}$ foi obtido no ponto central, foram utilizadas essas concentrações de $\mathrm{Fe}^{2+}$ e $\mathrm{Ni}^{2+}$ como nível 0 na elaboração do planejamento Composto Central, enquanto que para a relação $\mathrm{C}: \mathrm{N}: \mathrm{P}$, fator significativo para $\mathrm{VMPH}$, foi adotada a relação do ponto central $+3 \Delta$.

Os valores obtidos para as variáveis $\mathrm{VMPH}$ e $\mathrm{YH}_{2}$ com o planejamento Composto Central são apresentados na Tabela 16. O modelo quadrático se ajustou aos dados com $\mathrm{R}^{2}$ de 0,17 para $\mathrm{VMPH}$ e 0,35 para $\mathrm{YH}_{2}$. 
Tabela 16 - Matriz do planejamento Composto Central e resultados obtidos.

\begin{tabular}{|c|c|c|c|c|c|}
\hline \multirow[b]{2}{*}{ Ensaios } & \multicolumn{3}{|c|}{ Níveis dos fatores } & \multicolumn{2}{|c|}{ Variáveis } \\
\hline & C:N:P & $\mathrm{Fe}^{2+}$ & $\mathrm{Ni}^{+2}$ & VMPH $\left(\mathrm{mmol}^{-1} \mathrm{~h}^{-1}\right)$ & $\begin{array}{c}\mathrm{YH}_{2} \\
\left(\text { molH }_{2} \cdot \mathrm{mol}^{-\mathrm{sac}^{-1}}\right)\end{array}$ \\
\hline 1 & $-1,6818$ & 0 & 0 & $0,189 \pm 0,134$ & $1,00 \pm 0,30$ \\
\hline 2 & -1 & -1 & -1 & $0,073 \pm 0,174$ & $1,09 \pm 0,15$ \\
\hline 3 & -1 & -1 & 1 & $0,047 \pm 0,005$ & $1,15 \pm 0,15$ \\
\hline 4 & -1 & 1 & -1 & $0,064 \pm 0,019$ & $1,28 \pm 0,06$ \\
\hline 5 & -1 & 1 & 1 & $0,073 \pm 0,008$ & $1,16 \pm 0,09$ \\
\hline 6 & 0 & $-1,6818$ & 0 & $0,223 \pm 0,192$ & $1,15 \pm 0,10$ \\
\hline 7 & 0 & 0 & $-1,6818$ & $0,070 \pm 0,014$ & $1,23 \pm 0,12$ \\
\hline C & 0 & 0 & 0 & $0,152 \pm 0,163$ & $1,19 \pm 0,19$ \\
\hline 8 & 0 & 0 & 1,6818 & $0,230 \pm 0,207$ & $1,22 \pm 0,06$ \\
\hline 9 & 0 & 1,6818 & 0 & $0,114 \pm 0,035$ & $1,15 \pm 0,10$ \\
\hline 10 & 1 & -1 & -1 & $0,069 \pm 0,003$ & $1,33 \pm 0,23$ \\
\hline 11 & 1 & -1 & 1 & $0,066 \pm 0,028$ & $1,38 \pm 0,05$ \\
\hline 12 & 1 & 1 & -1 & $0,065 \pm 0,010$ & $1,58 \pm 0,23$ \\
\hline 13 & 1 & 1 & 1 & $0,034 \pm 0,015$ & $1,12 \pm 0,28$ \\
\hline 14 & 1,6818 & 0 & 0 & $0,051 \pm 0,042$ & $1,09 \pm 0,23$ \\
\hline
\end{tabular}

$\mathrm{Na}$ construção de cada superfície de resposta (Figura 21), foi adotado o nível crítico estimado pelo modelo para os fatores que não foram significativos para a variável em questão, ou seja $\mathrm{Ni}^{+2}$ no ajuste de $\mathrm{VMPH}$ e C:N:P ao ajustar HY. O valor máximo de VMPH estimado pelo modelo foi $0,199 \mathrm{mmol}^{-1} \mathrm{~h}^{-1}$ para relação $\mathrm{C}: \mathrm{N}: P$ de 11:3:1 e Ni ${ }^{+2}$ na concentração $0,015 \mathrm{mg} \mathrm{L}^{-1}$, contudo a concentração de $\mathrm{Fe}^{+2}$ crítica encontrada foi $-1,98 \mathrm{mg} \cdot \mathrm{L}^{-1}$ (Figura 21A). No caso de $\mathrm{YH}_{2}$, o modelo não obteve máximo, apenas um mínimo local, e o valor da variável aumenta nas regiões em que ou a concentração de $\mathrm{Ni}^{+2}$ ou a de $\mathrm{Fe}^{+2}$ se tornam negativas (Figura 21B).
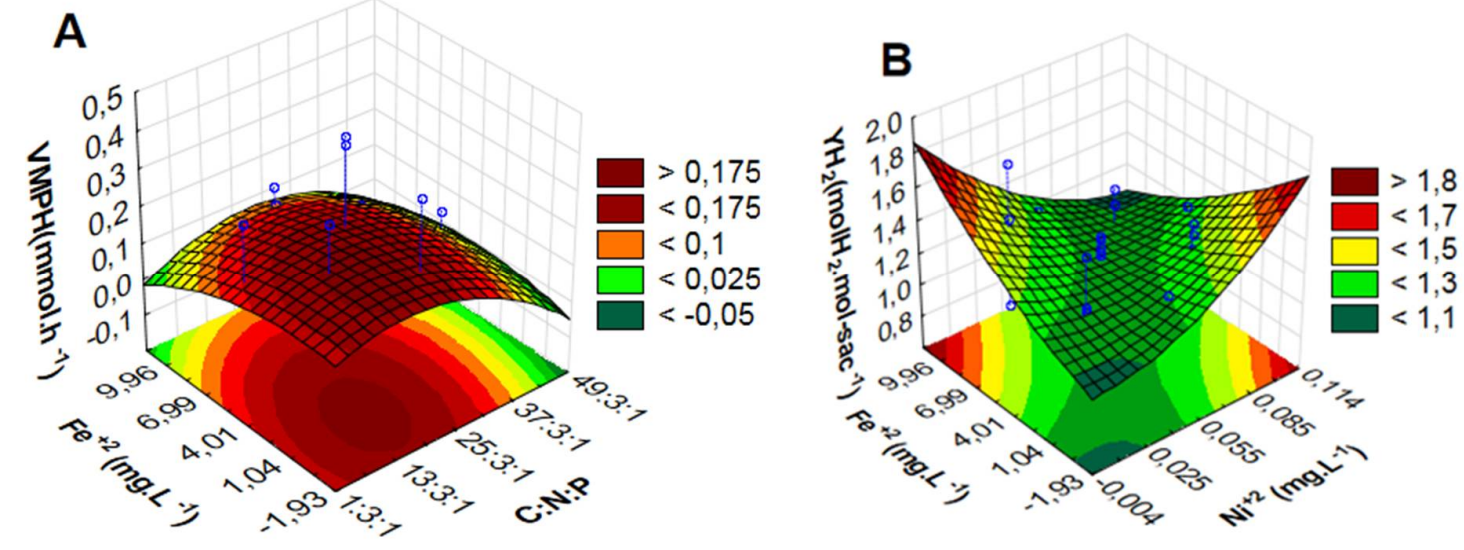

Figura 21 - Superfícies de resposta das variáveis VPH (A) e $\mathrm{YH}_{2}$ (B) em função de seus respectivos fatores influentes. 
Como os ensaios foram divididos em duas etapas, devido à inviabilidade de amostrar o biogás de todos os frascos nos intervalos desejados, foi adicionada a variável bloco ao modelo para verificar se a causa da falta de ajuste dos dados foi algum fator externo, como mudança de temperatura da câmara ao longo do experimento. $O$ modelo alterado mostrou aumento do ajuste $R^{2}$ para 0,44 em relação a $\mathrm{YH}_{2}$, contudo, o ponto crítico encontrado pelo modelo se manteve como mínimo local e não foi verificada melhoria com relação à VMPH. A hipótese para o comportamento das variáveis seria o fato da faixa de $\mathrm{C}: \mathrm{N}: \mathrm{P}$ adotada nos ensaios do Composto Central ser bastante inferior à adota no primeiro planejamento, cujo valor máximo é 1,3 vez inferior ao valor mínimo adotado em Plackett-Burman. Assim, a alta concentração de nitrogênio na faixa de $\mathrm{C}: \mathrm{N}: \mathrm{P}$ no terceiro planejamento, que resultou em produção de biomassa estatisticamente superior ao primeiro ensaio, pode ter levado à alteração da rota metabólica por excesso de microrganismos.

Dessa maneira, novo ensaio foi realizado utilizando blocagem no planejamento e variando apenas as concentrações de $\mathrm{Fe}^{+2}$ e $\mathrm{Ni}^{+2}$ e utilizando a relação C:N:P adotada na operação dos reatores (390:3:1). Os resultados são apresentados na Tabela 17.

Tabela 17 - Matriz do planejamento Composto Central variando apenas $\mathrm{Fe}^{+2}$ e $\mathrm{Ni}^{+2}$ e resultados obtidos.

\begin{tabular}{cccc}
\hline Ensaios & $\begin{array}{c}\text { Níveis dos fatores } \\
\mathbf{F e}^{2+}\end{array}$ & $\mathbf{N i}^{+2}$ & $\begin{array}{c}\mathbf{Y H}_{\mathbf{2}} \\
\left(\mathbf{m o l H}_{\mathbf{2}} \cdot \mathbf{m o l}-\mathbf{s a c} \mathbf{- 1}^{-1}\right)\end{array}$ \\
\hline 1 & -1 & -1 & $2,13 \pm 0,04$ \\
2 & -1 & 1 & $2,09 \pm 0,26$ \\
$\mathrm{C}$ & 0 & 0 & $2,12 \pm 0,03$ \\
3 & 1 & -1 & $1,77 \pm 0,13$ \\
4 & 1 & 1 & $1,78 \pm 0,12$ \\
5 & $-\sqrt{ } 2$ & 0 & $2,41 \pm 0,08$ \\
6 & 0 & $-\sqrt{2}$ & $2,63 \pm 0,11$ \\
7 & 0 & 0 & $2,67 \pm 0,07$ \\
8 & 0 & $\sqrt{2}$ & $2,24 \pm 0,05$ \\
9 & $\sqrt{2}$ & 0 & $2,69 \pm 0,35$ \\
\hline
\end{tabular}

O modelo apresentou $R^{2}$ de 0,75 e significância para a interferência dos blocos, ou seja, condições ambientais diferentes na execução dos dois blocos interferiram no experimento. Dessa forma, foram construídas duas superfícies de resposta uma para o bloco 1 (Figura 22A) e para o bloco 2 (Figura 22B). 
A

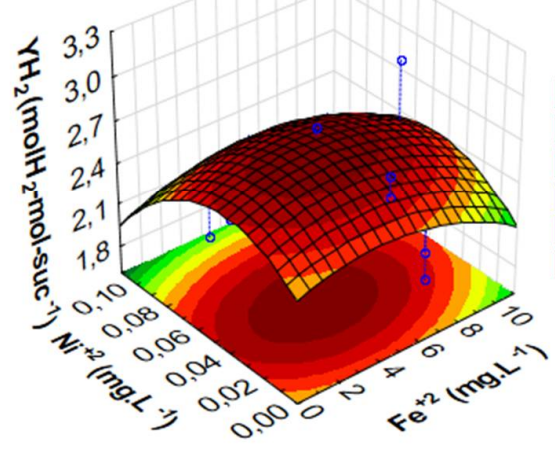

B

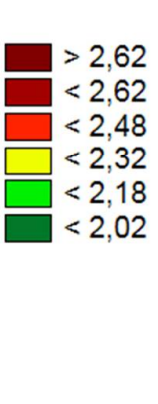

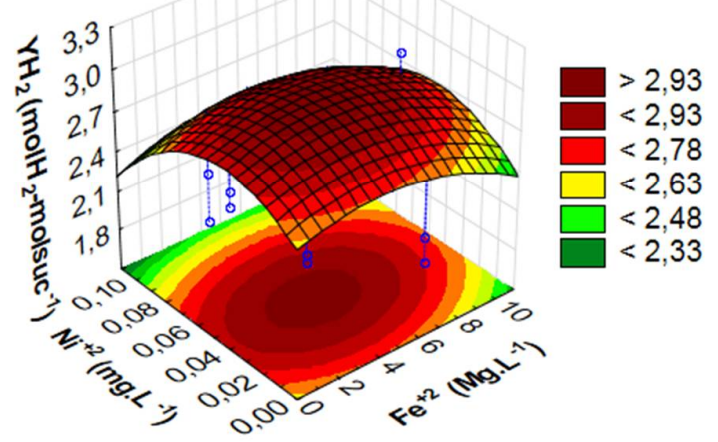

Figura 22 - Superfície de resposta para a variável $\mathrm{YH}_{2}$ em relação às concentrações de $\mathrm{Fe}^{2+}$ e $\mathrm{Ni}^{2+}$.

O teste também foi significativo para o coeficiente quadrático de $\mathrm{Ni}^{+2}$, porém não foi obtida significância estatística para os demais fatores da equação. As concentrações de nutrientes que resultaram no ponto máximo de produção foram estimadas em $4,53 \mathrm{mgFe}^{+2} \cdot \mathrm{L}^{-1}$ e $0,045 \mathrm{mgNi}^{+2} \cdot \mathrm{L}^{-1}$. O $\mathrm{YH}_{2}$ máximo previsto pela Equação 34 variou entre 2,67 e 2,96 $\mathrm{molH}_{2} \cdot \mathrm{mol}_{-\mathrm{sac}^{-1}}$, conforme eram consideradas pertencentes ao primeiro ou segundo bloco.

$$
\begin{gathered}
\mathrm{YH}_{2}=2,045+0,274 \mathrm{~B}+0,53 C_{\mathrm{Fe}+2}-0,007 C_{\mathrm{Fe}+2}^{2}+10,940 C_{\mathrm{Ni}+2} \\
-130,305 C_{\mathrm{Ni+2}}^{2}+0,180 C_{\mathrm{Fe}+2} C_{\mathrm{Ni+2}} \text { Equação } 36
\end{gathered}
$$

A concentração de $\mathrm{Fe}^{+2}$ encontrada como ponto máximo foi em torno de 10 vezes superior à utilizada nas operações dos reatores contínuos $\left(0,50 \mathrm{mgFe}{ }^{+2} \cdot \mathrm{L}^{-1}\right)$, já a concentração de $\mathrm{Ni}^{+2}$ otimizada indica um excesso de quase 2,5 vezes no substrato sintético que alimentava os reatores. Assim, produção de $\mathrm{H}_{2}$ por reatores anaeróbios termofílicos com biomassa proveniente do processo de autofermentação pode ser melhorada utilizando as concentrações obtidas nos ensaios em batelada. 


\section{CONCLUSÕES}

Através da operação de três configurações de reatores: UASB operado com TDH de 12, 6 e 2 h; tubular com leito empacotado (TCS) e tubular sem suporte (TSS) operados com TDH de 2 e 0,5h, pôde-se concluir que o TDH de $2 \mathrm{~h}$ foi o mais adequado para a produção de $\mathrm{H}_{2}$, sendo que as configurações TCS2 e U2 apresentam as melhores eficiências, com rota metabólica direcionada para a produção de etanol. Porém, por ter também demonstrado estabilidade, TCS2 pode ser apontado como a configuração mais eficiente entre as testadas.

Com TDH de $2 \mathrm{~h}$, o material suporte para agregação da biomassa se mostrou diretamente relacionado com a transferência de massa, resultando em menor teor de $\mathrm{H}_{2}$ no biogás quando presente, porém, permitindo maior contato entre os microrganismos e o substrato, o que melhorou a conversão de sacarose e resultou em maior produção de $\mathrm{H}_{2}$. Nesse sentido, o reator UASB apresentou uma situação intermediária entre o leito empacotado e a completa ausência de suporte, uma vez que a biomassa acidogênica pôde aderir aos grânulos de inóculo para se manter no reator, além do auxílio do dispositivo trifásico do reator. Com o TDH de $0,5 \mathrm{~h}$, a presença ou ausência de material suporte teve interferência apenas no direcionamento das rotas metabólicas, mas resultou em produção de $\mathrm{H}_{2}$ e conversão de sacarose similares.

A diminuição do TDH no reator UASB de 12 para $2 \mathrm{~h}$ resultou em aumento da transferência de massa sem prejudicar o processo, melhorando a eficiência na conversão de sacarose e aumentando a produção de $\mathrm{H}_{2}$. Já para os reatores tubulares com e sem leito empacotado, a diminuição do TDH de 2 para 0,5 h resultou em aumento da teor de $\mathrm{H}_{2}$ no biogás, mas o consequente aumento da COV de 24 para $96 \mathrm{gDQO} \cdot \mathrm{L}^{-1} \cdot \mathrm{d}^{-1}$ direcionou o metabolismo dos microrganismos às rotas de consumo de $\mathrm{H}_{2}$ para a produção de ácido acético ou metanol, diminuindo a eficiência dos reatores na produção de $\mathrm{H}_{2}$. 
O estudo indicou, ainda, que as condições ambientais às quais os microrganismos são submetidos em operações contínuas exerceram papel mais importante na seleção do consórcio microbiano que a origem do inóculo.

Verificou-se que o ferro e o níquel tem efeito sobre o coeficiente de rendimento de $\mathrm{H}_{2}\left(\mathrm{YH}_{2}\right)$ e o ferro e relação $\mathrm{C}: \mathrm{N}: \mathrm{P}$ afetam a velocidade molar de produção de $\mathrm{H}_{2}(\mathrm{VMPH})$. As concentrações ótimas de $\mathrm{Fe}^{+2} \mathrm{e} \mathrm{Ni}^{+2}$ encontradas foram $4,53 \mathrm{mgFe}{ }^{+2} \cdot \mathrm{L}^{-1}$ e $0,045 \mathrm{mgNi}{ }^{+2} \cdot \mathrm{L}^{-1}$. O $\mathrm{YH}_{2}$ máximo previsto está na faixa entre 2,67 e 2,96 molH $_{2} \cdot \mathrm{mol}_{-\mathrm{sac}^{-1}}$. Já a relação C:N:P ótima não pôde ser determinada, mas os resultados indicaram que para relações inferiores a 100:3:1 o crescimento biomassa passa a ser significativamente superior e pode interferir na produção de $\mathrm{H}_{2}$.

Assim, espera-se que o presente estudo sirva de embasamento para a escolha da configuração de reator para produção termofílica de $\mathrm{H}_{2}$ mais adequada ao objetivo desejado, além de contribuir para a melhoria da produção de $\mathrm{H}_{2}$ através da complementação de nutrientes. 


\section{SUGESTÕES PARA TRABALHOS FUtUROS}

O presente trabalho apresenta alguns avanços para pesquisa em produção de $\mathrm{H}_{2}$ em reatores termofílicos, mas deixa algumas lacunas a serem preenchidas por trabalhos posteriores:

- Operação de reator UASB utilizando a autoinoculação;

- Avaliação e quantificação da produção de polímeros em reatores sob condições de estresse;

- Determinação dos parâmetros cinéticos dos reatores estudados através da modelagem dos dados obtidos;

- Identificação das comunidades microbianas desenvolvidas nos reatores, especialmente a responsável pela produção do metanol, por ser uma rota pouco citada na literatura sobre produção de $\mathrm{H}_{2}$;

- Utilização das concentrações ótimas de níquel e ferro em reatores termofílicos contínuos;

- Determinação da melhor relação C:N:P para a produção termofílica de $\mathrm{H}_{2}$. 


\section{REFERÊNCIAS BIBLIOGRÁFICAS}

Akutsu, Y., Lee, D.-Y., Chi, Y.-Z., Li, Y.-Y., Harada, H., \& Yu, H.-Q. (2009). Thermophilic fermentative hydrogen production from starch-wastewater with biogranules. International Journal of Hydrogen Energy, 34(12), 5061-5071. doi:10.1016/j.jhydene.2009.04.024

American Public Health Association (APHA), American Water Works Association (AWWA ), \& Water Environment Federation. (2005). Standard Methods for the Examination of Water and Wastewater (21st ed., p. 1368). Washington, DC: American Public Health Association.

Angenent, L. T., Karim, K., Al-Dahhan, M. H., Wrenn, B. a, \& Domíguez-Espinosa, R. (2004). Production of bioenergy and biochemicals from industrial and agricultural wastewater. Trends in Biotechnology, 22(9), 477-85. doi:10.1016/j.tibtech.2004.07.001

Babu, V. L., Mohan, S. V., \& Sarma, P. N. (2009). Influence of reactor configuration on fermentative hydrogen production during wastewater treatment. International Journal of Hydrogen Energy, 34(8), 3305-3312. doi:10.1016/j.jhydene.2009.02.011

Bailey, J. E., \& Ollis, D. F. (1986). Biochemical engineering fundamentals (2nd ed., p. 984). New York: McGraw-Hill, Inc.

Barton, L. L. (2005). Structural and Functional Relationships in Prokaryotes (p. 818). New York: Springer-Verlag. doi:10.1007/b138652

Cai, G., Jin, B., Monis, P., \& Saint, C. (2011). Metabolic flux network and analysis of fermentative hydrogen production. Biotechnology Advances, 29(4), 375-87. doi:10.1016/j.biotechadv.2011.02.001

Chang, J., Lee, K., \& Lin, P. (2002). Biohydrogen production with fixed-bed bioreactors. International Journal of Hydrogen Energy, 27, 1167-1174.

Chou, C.-J., Jenney, F. E., Adams, M. W. W., \& Kelly, R. M. (2008). Hydrogenesis in hyperthermophilic microorganisms: implications for biofuels. Metabolic Engineering, 10(6), 394-404. doi:10.1016/j.ymben.2008.06.007

Del Nery, V. (1987). Utilização de lodo anaeróbio imobilizado em gel no estudo de partida de reatores de fluxo ascendente com manta de lodo. Universidade de São Paulo. 
Dong, F., Li, W.-W., Sheng, G.-P., Tang, Y., Yu, H.-Q., \& Harada, H. (2011). An online-monitored thermophilic hydrogen production UASB reactor for long-term stable operation. International Journal of Hydrogen Energy, 36(21), 1355913565. doi:10.1016/j.jijhydene.2011.08.010

Donot, F., Fontana, a., Baccou, J. C., \& Schorr-Galindo, S. (2012). Microbial exopolysaccharides: Main examples of synthesis, excretion, genetics and extraction. Carbohydrate Polymers, 87(2), 951-962. doi:10.1016/j.carbpol.2011.08.083

Fernandes, B. S., Saavedra, N. K., Maintinguer, S. I., Sette, L. D., Oliveira, V. M., Varesche, M. B. a, \& Zaiat, M. (2013). The effect of biomass immobilization support material and bed porosity on hydrogen production in an upflow anaerobic packed-bed bioreactor. Applied Biochemistry and Biotechnology, 170(6), 1348-66. doi:10.1007/s12010-013-0262-7

Fogler, H. S. (1999). Elements of Chemical Reaction hngineering (3rd ed., p. 967). New Jersey: Prentice-Hall.

Fox, P., \& Pohland, F. G. (1994). Anaerobic treatment applications and fundamentals: substrate specificity during phase separation, 66(5), 716-724.

Freitas, F., Alves, V. D., \& Reis, M. a M. (2011). Advances in bacterial exopolysaccharides: from production to biotechnological applications. Trends in Biotechnology, 29(8), 388-98. doi:10.1016/j.tibtech.2011.03.008

Gavala, H., Skiadas, I., \& Ahring, B. (2006). Biological hydrogen production in suspended and attached growth anaerobic reactor systems. International Journal of Hydrogen Energy, 31(9), 1164-1175. doi:10.1016/j.ijhydene.2005.09.009

Griffiths, R. I., Whiteley, A. S., O'Donnell, A. G., \& Bailey, M. J. (2000). Rapid method for coextraction of DNA and RNA from natural environments for analysis of ribosomal DNA- and rRNA-based microbial community composition. Applied and Environmental Microbiology, 66(12), 5488-91.

Hallenbeck, P. C. (2009). Fermentative hydrogen production: Principles, progress, and prognosis. International Journal of Hydrogen Energy, 34(17), 7379-7389. doi:10.1016/j.ijhydene.2008.12.080

Hallenbeck, P. C., Abo-Hashesh, M., \& Ghosh, D. (2012). Strategies for improving biological hydrogen production. Bioresource Technology, 110, 1-9. doi:10.1016/j.biortech.2012.01.103

Hawkes, F. R. (2002). Sustainable fermentative hydrogen production: challenges for process optimisation. International Journal of Hydrogen Energy, 27(11-12), 1339-1347. doi:10.1016/S0360-3199(02)00090-3

Hawkes, F. R., Hussy, I., Kyazze, G., Dinsdale, R., \& Hawkes, D. (2007). Continuous dark fermentative hydrogen production by mesophilic microflora: Principles and 
progress. International Journal of Hydrogen Energy, 32(2), 172-184. doi:10.1016/j.jhydene.2006.08.014

Jung, K.-W., Kim, D.-H., Lee, M.-Y., \& Shin, H.-S. (2012). Two-stage UASB reactor converting coffee drink manufacturing wastewater to hydrogen and methane. International Journal of Hydrogen Energy, 37(9), 7473-7481. doi:10.1016/j.jhydene.2012.01.150

Karlsson, A., Vallin, L., \& Ejlertsson, J. (2008). Effects of temperature, hydraulic retention time and hydrogen extraction rate on hydrogen production from the fermentation of food industry residues and manure. International Journal of Hydrogen Energy, 33(3), 953-962. doi:10.1016/j.ijhydene.2007.10.055

Kongjan, P., \& Angelidaki, I. (2010). Extreme thermophilic biohydrogen production from wheat straw hydrolysate using mixed culture fermentation: effect of reactor configuration. Bioresource Technology, 101(20), 7789-96. doi:10.1016/j.biortech.2010.05.024

Kongjan, P., Min, B., \& Angelidaki, I. (2009). Biohydrogen production from xylose at extreme thermophilic temperatures $\left(70^{\circ} \mathrm{C}\right)$ by mixed culture fermentation. Water Research, 43(5), 1414-24. doi:10.1016/j.watres.2008.12.016

Lee, K., Lo, Y., Lin, P., \& Chang, J. (2006). Improving biohydrogen production in a carrier-induced granular sludge bed by altering physical configuration and agitation pattern of the bioreactor. International Journal of Hydrogen Energy, 31(12), 1648-1657. doi:10.1016/j.ijhydene.2005.12.020

Lee, Y. J., Miyahara, T., \& Noike, T. (2001). Effect of iron concentration on hydrogen fermentation. Bioresource Technology, 80(3), 227-31.

Leite, J., Fernandes, B. S., Pozzi, E., Barboza, M., \& Zaiat, M. (2008). Application of an anaerobic packed-bed bioreactor for the production of hydrogen and organic acids. International Journal of Hydrogen Energy, 33(2), 579-586. doi:10.1016/j.jhydene.2007.10.009

Levenspiel, O. (1999). Chemical Reaction Engineering (3rd ed., p. 668). New York: John Wiley \& Sons.

Lima, D. M. F., Moreira, W. K., \& Zaiat, M. (2013). Comparison of the use of sucrose and glucose as a substrate for hydrogen production in an upflow anaerobic fixed-bed reactor. International Journal of Hydrogen Energy, 38(35), 1507415083. doi:10.1016/j.ijhydene.2013.09.003

Lima, D. M. F., \& Zaiat, M. (2012). The influence of the degree of back-mixing on hydrogen production in an anaerobic fixed-bed reactor. International Journal of Hydrogen Energy, 37(12), 9630-9635. doi:10.1016/j.ijhydene.2012.03.097

Lin, C., \& Lay, C. (2005). A nutrient formulation for fermentative hydrogen production using anaerobic sewage sludge microflora. International Journal of Hydrogen Energy, 30(3), 285-292. doi:10.1016/j.ijhydene.2004.03.002 
Lin, C. Y., \& Lay, C. H. (2004). Carbon/nitrogen-ratio effect on fermentative hydrogen production by mixed microflora. International Journal of Hydrogen Energy, 29(1), 41-45. doi:10.1016/S0360-3199(03)00083-1

Liu, Q., Zhang, X., Zhou, Y., Zhao, A., Chen, S., Qian, G., \& Xu, Z. P. (2011). Optimization of fermentative biohydrogen production by response surface methodology using fresh leachate as nutrient supplement. Bioresource Technology, 102(18), 8661-8. doi:10.1016/j.biortech.2011.03.002

López, I., \& Borzacconi, L. (2010). UASB reactor hydrodynamics: residence time distribution and proposed modelling tools. Environmental Technology, 31(6), 591-600. doi:10.1080/09593331003646638

Luo, G., Karakashev, D., Xie, L., Zhou, Q., \& Angelidaki, I. (2011). Long-term effect of inoculum pretreatment on fermentative hydrogen production by repeated batch cultivations: homoacetogenesis and methanogenesis as competitors to hydrogen production. Biotechnology and Bioengineering, 108(8), 1816-27. doi:10.1002/bit.23122

Luo, G., Xie, L., Zou, Z., Wang, W., \& Zhou, Q. (2010). Evaluation of pretreatment methods on mixed inoculum for both batch and continuous thermophilic biohydrogen production from cassava stillage. Bioresource Technology, 101(3), 959-64. doi:10.1016/j.biortech.2009.08.090

Madigan, M. T., Martinko, J. M., Stahl, D. A., \& Clark, D. P. (2012). Brock Biology of Microorganisms (13th ed., p. 1152). San Francisco: Benjamin Cummings.

Mahmoud, N., Zeeman, G., Gijzen, H., \& Lettinga, G. (2003). Solids removal in upflow anaerobic reactors, a review. Bioresource Technology, 90(1), 1-9. doi:10.1016/S0960-8524(03)00095-6

Muyzer, G., de Waal, E. C., \& Uitterlinden, A. G. (1993). Profiling of complex microbial populations by denaturing gradient gel electrophoresis analysis of polymerase chain reaction-amplified genes coding for 16S rRNA. Applied and Environmental Microbiology, 59(3), 695-700.

Nardi, I. R. de, Zaiat, M., \& Foresti, E. (1999). Influence of the tracer characteristics on hydrodynamic models of packed-bed bioreactors. Bioprocess Engineering, $21,469-476$.

Nübel, U., Engelen, B., Felske, A., Snaidr, J., Wieshuber, A., Amann, R. I., ... Backhaus, H. (1996). Sequence Heterogeneities of Genes Encoding 16S rRNAs in Paenibacillus polymyxa Detected by Temperature Gradient Gel Electrophoresis. Journal of Bacteriology, 178(19), 5636-5643.

Othong, S., Poonsuk, P., Intrasungkha, N., Dhamwichukorn, S., \& Birkeland, N.-K. (2008). Optimization of simultaneous thermophilic fermentative hydrogen production and COD reduction from palm oil mill effluent by Thermoanaerobacterium-rich sludge. International Journal of Hydrogen Energy, 33(4), 1221-1231. doi:10.1016/j.ijhydene.2007.12.017 
Penteado, E. D., Lazaro, C. Z., Sakamoto, I. K., \& Zaiat, M. (2013). Influence of seed sludge and pretreatment method on hydrogen production in packed-bed anaerobic reactors. International Journal of Hydrogen Energy, 38(14), 61376145. doi:10.1016/j.ijhydene.2013.01.067

Ren, N., Li, J., Li, B., Wang, Y., \& Liu, S. (2006). Biohydrogen production from molasses by anaerobic fermentation with a pilot-scale bioreactor system. International Journal of Hydrogen Energy, 31(15), 2147-2157. doi:10.1016/j.jhydene.2006.02.011

Ren, T., Mu, Y., Ni, B., \& Yu, H. (2009). Hydrodynamics of Upflow Anaerobic Sludge Blanket Reactors. AlChE Journal, 55(2), 516-528. doi:10.1002/aic

Saady, N. M. C. (2013). Homoacetogenesis during hydrogen production by mixed cultures dark fermentation: Unresolved challenge. International Journal of Hydrogen Energy, 38(30), 13172-13191. doi:10.1016/j.ijhydene.2013.07.122

Show, K.-Y., Zhang, Z.-P., Tay, J.-H., Liang, D. T., Lee, D.-J., Ren, N., \& Wang, A. (2010). Critical assessment of anaerobic processes for continuous biohydrogen production from organic wastewater. International Journal of Hydrogen Energy, 35(24), 13350-13355. doi:10.1016/j.jijhydene.2009.11.110

Sinha, P., \& Pandey, A. (2011). An evaluative report and challenges for fermentative biohydrogen production. International Journal of Hydrogen Energy, 36(13), 7460-7478. doi:10.1016/j.ijhydene.2011.03.077

Tanisho, S., \& Ishiwata, Y. (1995). Continuous hydrogen production from molasses by fermentation using urethane foam as a support of flocks. International Journal of Hydrogen Energy, 20(7), 541-545.

Thauer, R. K., Jungermann, K., \& Decker, K. (1977). Energy conservation in chemotrophic anaerobic bacteria. Bacteriological Reviews, 41(3), 809.

Vignais, P. M., \& Colbeau, A. (2004). Molecular Biology of Microbial Hydrogenases. Current Issues in Molecular Biology, 6, 159-188.

Wang, J., \& Wan, W. (2008). Effect of Fe2+ concentration on fermentative hydrogen production by mixed cultures. International Journal of Hydrogen Energy, 33(4), 1215-1220. doi:10.1016/j.ijhydene.2007.12.044

Wang, J., \& Wan, W. (2008). Influence of Ni2+ concentration on biohydrogen production. Bioresource Technology, 99(18), 8864-8. doi:10.1016/j.biortech.2008.04.052

Wang, J., \& Wan, W. (2009). Factors influencing fermentative hydrogen production: A review. International Journal of Hydrogen Energy, 34(2), 799-811. doi:10.1016/j.jjhydene.2008.11.015

Xiaolong, H., Minghua, Z., Hanqing, Y., Qinqin, S., \& Lecheng, L. (2006). Effect of Sodium lon Concentration on Hydrogen Production from Sucrose by Anaerobic 
Hydrogen-producing Granular Sludge1. Chinese Journal of Chemical Engineering, 14(4), 511-517. doi:10.1016/S1004-9541(06)60106-7

Xin, J.-Y., Zhang, Y.-X., Zhang, S., Xia, C.-G., \& Li, S.-B. (2007). Methanol production from $\mathrm{CO} 2$ by resting cells of the methanotrophic bacterium Methylosinus trichosporium IMV 3011. Journal of Basic Microbiology, 47(5), 426-35. doi:10.1002/jobm.200710313

Young, J. C., \& McCarty, P. L. (1969). The anaerobic filter for waste treatment. Journal (Water Pollution Control Federation), 41(5), R160 - R173.

Yu, H., \& Mu, Y. (2006). Biological Hydrogen Production in a UASB Reactor With Granules . II: Reactor Performance in 3-Year Operation. Biotechnology and Bioengineering, 94(5), 988-995. doi:10.1002/bit

Zhang, F., Zhang, Y., Chen, M., \& Zeng, R. J. (2012a). Hydrogen supersaturation in thermophilic mixed culture fermentation. International Journal of Hydrogen Energy, 37(23), 17809-17816. doi:10.1016/j.ijhydene.2012.09.019

Zhang, F., Zhang, Y., Chen, M., \& Zeng, R. J. (2012b). Hydrogen supersaturation in thermophilic mixed culture fermentation. International Journal of Hydrogen Energy, 37(23), 17809-17816. doi:10.1016/j.jijhydene.2012.09.019

Zhao, B., Yue, Z., Zhao, Q., Mu, Y., Yu, H., Harada, H., \& Li, Y. (2008). Optimization of hydrogen production in a granule-based UASB reactor. International Journal of Hydrogen Energy, 33(10), 2454-2461. doi:10.1016/j.jhydene.2008.03.008

Zwietering, M. H., Jongenburger, I., Rombouts, F. M., \& van't Riet, K. (1990). Modeling of the bacterial growth curve. Applied and Environmental Microbiology, 56(6), 1875-81. 